\title{
DISTRIBUTION OF LEAD-210 AND POLONIUM-210 BETWEEN SOLUBLE AND PARTICULATE PHASES IN SEAWATER
}

During the past year, we have continued our investigations of $\mathrm{Pb}-210$ ( $T 1 / 2=22 y r)$ and Po-210 ( $T$ 1/2=138d) distributions in seawater and suspended particulate matter. The aim of this study, as discussed more fully in our preceding report (Spencer, 1974), is to further understand mechanisms and rates of scavenging and transport of materials by particulate matter in the sea.

Additional sampling was carried out during Cruise 86 of R/V ATLANTIS II in January, 1975, when approximately 50 samples (water samples and particulate samples combined) were collected at three stations in the Gulf of Maine. We are also analyzing plankton and sediment samples collected during that cruise. Combined with our earlier collections, these samples bring our totals to approximately 300 water samples and 200 particulate samples, all of which have now been analyzed for Po-210. Lead-210 analyses should be completed by September of this year.

Sampling and analytical procedures used in our laboratory were described in last year's report (Spencer, 1974). Our counting system has now been expanded to included eight alpha-detectors coupled through an eight-input router. to our Northern 1024-channel analyzer.

\section{RESULTS FROM THE NORTH ATLANTIC}

In Figures 1 and 2 are presented results from two Meteor stations for which we have completed both $\mathrm{Pb}-210$ and $\mathrm{Po-210}$ analyses. Station 18 is 


\section{DISCLAIMER}

This report was prepared as an account of work sponsored by an agency of the United States Government. Neither the United States Government nor any agency Thereof, nor any of their employees, makes any warranty, express or implied, or assumes any legal liability or responsibility for the accuracy, completeness, or usefulness of any information, apparatus, product, or process disclosed, or represents that its use would not infringe privately owned rights. Reference herein to any specific commercial product, process, or service by trade name, trademark, manufacturer, or otherwise does not necessarily constitute or imply its endorsement, recommendation, or favoring by the United States Government or any agency thereof. The views and opinions of authors expressed herein do not necessarily state or reflect those of the United States Government or any agency thereof. 


\section{DISCLAIMER}

Portions of this document may be illegible in electronic image products. Images are produced from the best available original document. 
is located over the western flank of the Mid-Atlantic Ridge, while Station 32 was occupied in the eastern basin approximately 500 miles southwest of Gibraltar. To the best of our knowledge, these represent the first profiles in which $\mathrm{Pb}-210$ and $\mathrm{Po}-210$ have both been measured in soluble and particulate forms. Analyses of Ra-226 are being made at Heidelberg, but these results are not yet available. Consequently, we have estimated $\mathrm{Ra}-226$ concentrations on the basis of their observed correlation with silica concentrations (W. S. Broecker, unpublished data; GEOSECS Atlantic Preliminary Data Reports).

\section{LEAD-210 AND POLONIUM-210 IN THE SURFACE OCEAN}

At both stations $\mathrm{Pb}-2,10$ activities near the surfacc exceed those of Ra-226 by as much as a factor of two or more. This excess is maintained by delivery of unsupported $\mathrm{Pb}-210$ from the atmosphere, where it is formed by radioactive decay of $\mathrm{Rn}-222$ (Rama, et al., 1961). The influence of this source is seen to penetrate to considerable depths in the water column: about $500 \mathrm{~m}$ at Station 18 and $1000 \mathrm{~m}$ at Station 32.

Polonium-210, on the other hand, is strongly depleted in surface water relative to its $\mathrm{Pb}-210$ parent. This effect results largely from the preferential scavenging of Po-210 by marine plankton. Shannon, et al. (1970) reported $\mathrm{Po}-210 / \mathrm{Pb}-210$ activity ratios of 2.5-5.5 for phytoplankton and 10-25 for zooplankton collected off the coast of South Africa. Turekian, et al. (1974) found a similar range of values for zooplankton and noted an inverse relation- 
ship with productivity, zooplankton from more productive waters having lower $\mathrm{Po}-210 / \mathrm{Pb}-210$ ratios. Our analyses of particulate matter collected near. the sea surface show enrichments of Po-210 by a factor of 2-4 relative to $\mathrm{Pb}-210$, similar to the phytoplankton ratios measured by Shannon, et al. $(1970)$

It is possible from our data to calculate the rate of Po-210 removal from the surface ocean. We may neglect the small input of Po-?1n from the atmosphere and the small changes that result from fluid exchange with. deeper water, and we require that production by decay of $\mathrm{Pb}-210$ be balanced by chemical removal and radioactive decay:

$$
\lambda_{2} A_{1}=\lambda_{2} A_{2}+k_{2} A_{2}
$$

where

$$
\begin{aligned}
\lambda_{2}= & \text { decay constant of Po-210 }\left(1.83 \mathrm{yr}^{-1}\right) \\
k_{2}= & \text { scavenging coefficient for Po-210 }\left(\mathrm{yr}^{-1}\right. \text {; scavenging assumed } \\
& \text { to be a first-order rate process }) \\
A_{1}= & \text { soluble Pb-210 activity }\left(\mathrm{dpm} \mathrm{cm} \mathrm{cm}^{-2}\right) \\
A_{2}= & \text { soluble Po-210 activity }\left(\mathrm{dpm} \mathrm{cm} \mathrm{cm}^{-2}\right) .
\end{aligned}
$$

From hydrographic observations the thickness of the mixed layer is taken to be $20 \mathrm{~m}$ at Station 18 and $100 \mathrm{~m}$ at Station 32. Calculated removal rates

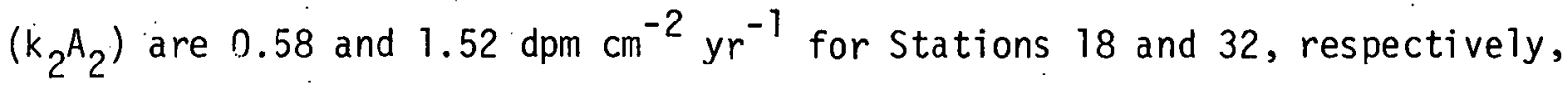
and corresponding residence times $\left(1 / k_{2}\right)$ are 0.17 and $0.47 \mathrm{yr}$. These parameters characterize the net transfer of Po-210 in the mixed layer from soluble to particulate form. 
knowledge of these transfer rates permits us to estimate mean exposure ages or residence times of particulate matter in the mixed layer. Particulate Po-210 is supplied by chemical transfer from the soluble form and by decay of particulate $\mathrm{Pb}-210$, and this supply is assumed to be balanced by sinking out of the mixed layer and radioactive decay:

$$
k_{2} A_{2}+\lambda_{2} A_{1 p}=R+\lambda_{2} A_{2 p}
$$

where

$$
\begin{aligned}
& R=\text { rate of removal by sinking }\left(\mathrm{dpm} \mathrm{cm}^{-2} \mathrm{yr}^{-1}\right) \\
& A_{1 p}=\text { particulate } \mathrm{Pb}-210 \text { activity }\left(\mathrm{dpm} \mathrm{cm} \mathrm{cm}^{-2}\right) \\
& A_{2 p}=\text { particulate } P_{0}-210 \text { activity }\left(\mathrm{dpm} \mathrm{cm} \mathrm{cm}^{-2}\right) .
\end{aligned}
$$

For Stations 18 and 32 , we calculate particle residence times of 0.050 and $0.096 \mathrm{yr}$. These times are short relative to the radioactive mean life of Po-210 $(0.55 \mathrm{yr})$ and relative to the residence times calculated above for soluble Po-210, and they imply. that the removal of Po-210 from the surface ocean is controlled largely by the rate at which Po-210 is incorporated into particulate phases.

Corresponding settling velocities for particulate matter of 400 and $1040 \mathrm{~m} \mathrm{yr}^{-1}\left(1.3\right.$ and $\left.3.3 \times 10^{-3} \mathrm{~cm} \mathrm{sec}^{-1}\right)$ may be calculated. However, much of the particle removal may result from grazing rather than from sinking (Riley, et al ; 1949).

We note that the short residence time of polonium in the surface ocean (a few months) is similar to that of other reactive elements such as thorium (Broecker, et al., 1973; Matsumoto, 1975). 
By using equations for $\mathrm{Pb}-210$ similar to (1) and (2), we may estimate the rate of removal that must be supported by the $\mathrm{Pb}-210$ flux from the atmosphere. These fluxes are estimated to be 0.22 and $0.33 \mathrm{dpm} \mathrm{cm}^{-2} \mathrm{yr}^{-1}$, which are in favorable agreement with estimates of Lambert and Nezami (1965) for the mean global $\mathrm{Pb}-210$ flux of 0.22 and $0.42 \mathrm{dpm} \mathrm{cm}^{-2} \mathrm{yr}^{-1}$ at $0-15^{\circ} \mathrm{N}$ and $15-45^{\circ} \mathrm{N}$. Residence times for $\mathrm{Pb}-210$ in the mixed layer of 1.9 and 5.2 yr have been calculated, in good agreement with the results of previous workers (Rama, et al., 1961; Shannon, et al., 1970; Tatsumoto and Patterson, 1963):

Calculations similar to the above have been performed by Turekian, et al. (1974), who obtained lower values for the atmospheric Pb-210 flux (0.05$\left.0.10 \mathrm{dpm} \mathrm{cm}^{-2} \mathrm{yr}^{-1}\right)$ and longer $\mathrm{Pb}-210$ residence times $(9-24 \mathrm{yr})$. The principal reason for the discrepancy lies in their assumption that the Po-210/Pb-210 transport ratio is represented by their activity ratios measured in zooplankton (ca 20) while we feel that our values in total suspended matter and those of Shannon, et al. (1970) in phytoplankton are more representative of the particulate flux.

An independent estimate of the atmospheric $\mathrm{Pb}-210$ delivery can be made by integrating our $\mathrm{Ra}-226$ and $\mathrm{Pb}-210$ profiles to depths at which the effect of surface input appears to be insignificant -- $500 \mathrm{~m}$ at Station 18 and $1000 \mathrm{~m}$ at Station 32. As discussed in the next section, $\mathrm{Pb}-210$ appears to be chemically scavenged throughout the water column, and, as an estimate of the scavenging rate in the upper layers, we use a chemical residence time of $60 \mathrm{yr}$, derived from our deep water data. If the decay of unsupported $\mathrm{Pb}-210$ and chemical removal are to be balanced by the atmospheric input, we 
require fluxes of 0.19 and $0.29 \mathrm{dpm} \mathrm{cm}^{-2} \mathrm{yr}^{-1}$, in good agreement with values estimated by considering the mixed layer only.

\section{SCAVENGING IN THE DEEP SEA}

Below depths of 500-1000 $\mathrm{m}$, we may regard the input of atmospheric $\mathrm{Pb}-210$ as being insignificantly small compared with the in situ generation of $\mathrm{Pb}-210$ following decay of $\mathrm{Ra}-226$. Rates of chemical removal are, therefore, readily calculated from measurements of parent and daughter decay rates. Both of our profiles show strong depletions of $\mathrm{Pb}-210$ throughout the deep water column and imply the operation of processes that remove $\mathrm{Pb}-210$ from the deep sea. Mean deep-ocean residence times for soluble $\mathrm{Pb}-210$ of 52 and $67 \mathrm{yr}$ have been calculated from our data. These results confirm the findings of Craig, et al. (1973) and their suggestion that the $\mathrm{Ra}-226 / \mathrm{Pb}-210$ disequilibrium is an ocean-wide phenomenon.

Following earlier suggestions by Goldberg (1954) and Krauskopf (1956), Craig, et al. (1973) assume that $\mathrm{Pb}-210$ is scavenged from the deep ocean by suspended particulate matter and eliminated by sinking. We have indeed found measurable $\mathrm{Pb}-210$ activities in our deep particulate samples ranging from $0.2-1.6 \mathrm{dpm} / 100 \mathrm{~kg}$ seawater. These values are well above those that we would attribute to terrigenous background $(<0.002 \mathrm{dpm} / 100 \mathrm{~kg})$, and we conclude that they represent $\mathrm{Pb}-210$ derived by scavenging from seawater. 
At any given level in the water column, a portion of the particulate $\mathrm{Pb}-210$ activity wil1 have been inherited from scavenging in the upper layers, and to assess rates of vertical transport we must observe increases in particulate activity with depth. No such increase is found at Station 32 , however, and this implies either that the residence time of particles is very short ( $<1 \mathrm{yr}$. ) at this location or that $\mathrm{Pb}-210$ is being scavenged at a remote sink toward which it is being transported by diffusion or advection. It should be noted that at both stations a divergence of the Ra-226 and $\mathrm{Pb}-210$ profiles occurs near the bottom, indicating a strong scavenging effect at the sediment-water interface. If such a process were operating at the boundaries of an ocean basin (continental margin, mid-oceanic ridge), its effect will be felt at distances approximated by $\left(K_{h} \tau\right)^{1 / 2}$, where $k_{h}$ is the horizontal eddy diffusion coefficient, and $\tau$ is the radioactive mean life $\left(30 \mathrm{yr}\right.$. for $\mathrm{Pb}-210$ ). Adopting a value for $\mathrm{K}_{\mathrm{h}}$ of $6 \times 10^{6} \mathrm{~cm}^{2} \mathrm{sec}^{-1}$ (Kuo and Veronis, 1973), we calculate a distance of about $750 \mathrm{~km}$. Both of our profiles are from locations close enough to basin boundaries that such an effect may be important in determining the extent and distribution of the $\mathrm{Ra}-226 / \mathrm{Pb}-210$ disequilibrium.

At Station 18 the increase in particulate Pb-210 activity helnw $2000 \mathrm{~m}$ presents a somewhat more reasonable picture of scavenging by sinking particles, but the values decrease again in the lowermost two samples. As we acquire data from other locations, we hope to determine which of these two types of profiles is more typical and to further evaluate the importance of reactions at the sediment-water interface. 
It is likely that Po-210, with its shorter half-life, will be a less ambiguous indicator of in situ processes than $\mathrm{Pb}-210$, because the influence of remote sources and sinks will be less. With the exception of two levels in the water column at Station 18, which will be discussed in the next section, we find a systematic depletion of soluble $\mathrm{Po}-210$ relative to $i$ ts $\mathrm{Pb}-210$ parent. The particulate matter is correspondingly enriched in $\mathrm{P}_{0}-210$, implying that Po-210 is being removed in situ and that it is being taken by the particles in preference to $\mathrm{Pb}-210$. This preferential uptake is similar to that noted previously for plankton and suspended matter in the surface ocean. Mean residence times for soluble Po-210 with respect to transfer to the particulate phase are 2-3 yr., about twenty times shorter than for $\mathrm{Pb}-210$. Increases in particulate Po-210 with depth are observed in both profiles, which are qualitatively consistent with the view that polonium is scavenged by sinking particles.

As previously noted, the contribution of Po-210 from the atmosphere is small compared with its production in the water column by decay of $\mathrm{Pb}-210$, and it is of interest to sum our soluble and particulate analyses and integrate them over the entire length of the water column to see how closely secular equilibrium is approached. Station 18 shows a nearly perfect balance, the waler column as à whole being in secular equilibrium. For Station 32 we. estimate a $13 \%$ Po-210 deficit ( $11 \%$ if the two surface values are omitted). While this result may be within error limits for summing this number of analyses, the difference lies in the direction that one would expect for preferential scavenging of Po-210. 
ORIGIN OF EXCESS POLONIUM-210 AT DEPTH

It is clear that $\mathrm{Po-210}$ is preferentially removed from seawater and enriched in particulate phases relative to $\mathrm{Pb}-210$. This behavior is reflected consistently in our data except for two levels in the water column at Station 18, where we find soluble Po-210 occurring in excess. A well-defined Po-210 maximum occurs at about $125 \mathrm{~m}$ and coincides with the subsurface mass of high-salinity water which is formed at slightly higher latitudes (Wust, 1964). A second maximum containing excess Po-210 appears at about $1200-1500 \mathrm{~m}$, between the low-salinity Antarctic Intermediate Water and the weak salinitymaximum of Mediterranean origin. Experimentally this second features is less well established, as only one point shows an excess within our 10 confidence limits. Until the existence of this second feature is confirmed in other profiles, we shall confine our discussion to the shallower layer.

We are presently analyzing surface water samples collected in the formation region of this high-salinity water to determine whether processes occurring at the air-sea interface could lead to Po-210 enrichments which would thus characterize the water mass. Such a possibility is suggested by recent results of Lambert (personal communication), who has measured enrichments of Po-210 in marine aerosols collected over the South Atlantic and Antarctic 0ceans. This enrichment, however, may be related to the injection of Po-210 from the sea surface into the atmosphere, as suggested by Turekian et al. (1974), and probably does not imply that excess Po-210 is being delivered to the ocean. 
If a Po-210 excess were being produced at the surface by some unknown mechanism, we can estimate the excess Po-210 flux that would be required to maintain it. We consider the horizontal distribution of excess Po-210 in the high-salinity layer, allow horizontal diffusion in one direction only, and neglect losses due to scavenging. The distribution is given by:

$$
k_{h} \partial^{2} C / \partial x^{2}=\lambda C
$$

where

$$
\begin{aligned}
& K_{h}=\text { horizontal eddy diffusion coefficient } \\
& \left.\lambda=\text { decay constant of Po-210 (1.83 } \mathrm{yr}^{-1}\right) \\
& C=\text { excess Po-210 (dpm/100 kg) } \\
& x=\text { distance from source }
\end{aligned}
$$

The solution is

$$
c=c_{0} e^{-\left(\lambda / K_{h}\right)^{1 / 2} x}
$$

where $C_{0}$ is the Po-210 excess at the surface. The excess Po-210 flux at the surface is

$$
F_{0}=\left(\lambda K_{h}\right)^{j / 2} C_{0}
$$

We take $x=100 \mathrm{~km}$ at the distance from Station 18 to the source region and $C=4 \mathrm{dpm} / 100 \mathrm{~kg}$ at $\mathrm{x}=100 \mathrm{~km}$. For $K_{h}=10^{6}-10^{8} \mathrm{~cm}^{2} \mathrm{sec}^{-1}$, an excess Po-210 flux at the surface of about $3000 \mathrm{dpm} \mathrm{cm}^{-2} \mathrm{yr}^{-1}$ would be required to maintain the subsurface maximum that we observe. This is orders of magnitude higher 
than the estimated $\mathrm{Pb}-210 \mathrm{flux}$ ( $\underline{\mathrm{ca}} 0.2 \mathrm{dpm} \mathrm{cm}^{-2} \mathrm{yr}^{-1}$ ). Allowing for chemical removal and mixing in other directions would make the required source even larger.

Because the subsurface Po-210 maximum cannot be explained by lateral transport without invoking an enormous source, it must be accounted for by in situ recycling below the euphotic zone. By integrating vertical profiles, we can estimate the rate of transfer of Po-210 from the surface layer, where it is depleted, to the subsurface layer, where it is enriched. The rates cal-

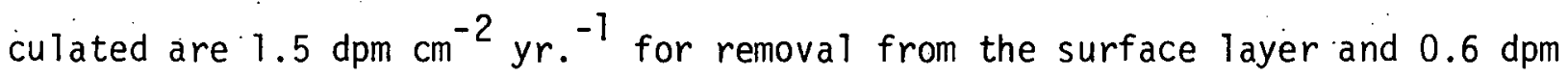
$\mathrm{cm}^{-2} \mathrm{yr}^{-1}$ for injection at depth. The subsurface input is thus easily accounted for by local recycling. Such recycling is probably of general occurrence, but results in an observable maximum only in areas of very stable stratification in the upper layers of the water column. A similar behavior for $\mathrm{Pb}-210$ is implied, and may be largely responsible for the deep vertical penetration of excess $\mathrm{Pb}-210$ observed at both our stations.

\section{LEAD-210 DATING OF SHALLOW-WATER SEDIMENTS}

In shallow water, unsupported $\mathrm{Pb}-2.10$ delivered from the atmosphere is rapidly removed to the bottom, where its exponential decay with time forms the basis for datinq rapidly accumulating lake and roastal marine sedimente. This tool has recently been examined by a number of investigators (Koide, et al., 1972; Krishnaswamy et ál., 1971; Robbins and Edgington, 1975).

We have measured $\mathrm{Pb}-210$ in sections of a core taken from Buzzards Bay, Massachusetts, by Dr. J. W. Farrington. Dried sediment samples were treated by leaching with hot, concentrated $\mathrm{HNO}_{3}$ for four hours in the presence of Po-208 
tracer. The hot leachate was separated by filtration through glass fiber filters and the nitric acid eliminated by evaporation with periodic additions of concentrated $\mathrm{HCl}$. Sample solutions were then made $2 \underline{\mathrm{N}}$ in $\mathrm{HCl}$ by dilution with distilled water and polonium analyses completed according to our usual procedure (Spencer, 1974). It is assumed that $\mathrm{Pb}-210$ and $\mathrm{Po}-210$ are in secular equilibrium throughout the length of the core, and our results are reported as $\mathrm{Pb}-210(\mathrm{dpm} / \mathrm{g}$ dried sediment).

Figure 3 is a semi-logarithmic plot of excess $\mathrm{Pb}-210$ vs. depth. The supported $\mathrm{Pb}-210$ background $(1.24 \pm 0.15 \mathrm{dpm} / \mathrm{g})$ was estimated by averaging three analyses from deeper levels of the core at which $\mathrm{Pb}-210$ activity was independent of depth. For constant rates of sediment accumulation and delivery of $\mathrm{Pb}-210$ to the sediment surface, the data should plot as a straight line given by

$$
\log A=\log A_{0}-\lambda x / S
$$

where

$$
\begin{aligned}
& A=\text { activity of unsupported } P b-210 \text { at depth } x \\
& A_{0}=\text { activity at } x=0 \\
& \lambda=\text { decay constant of } P h-210\left(0.0312 \mathrm{yr}^{-1}\right) \\
& S=\text { sedimentation rate }
\end{aligned}
$$

Our curve appears to consist of two distinct portions, each of which may be approximately fit by straight lines with different slopes, with a break occurring at about $12 \mathrm{~cm}$. Apparent sedimentation rates given by the slopes. 


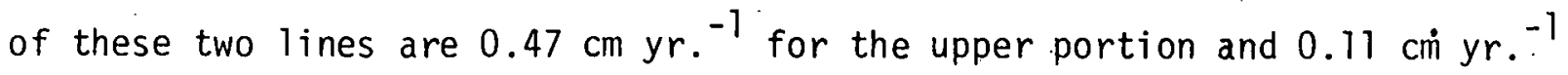
for the lower portion.

Integration of these two portions of the curve, however, reveals that such an increase in sedimentation would have required a simultaneous increase in the rate of $\mathrm{Pb}-210$ supply. Otherwise, we should observe a sudden decrease in activity by dilution just above the $12 \mathrm{~cm}$ level.

It appears more likely to us that the $\mathrm{Pb}-210$ distribution in the upper level of the core is largely controlled by biological mixing processes. This interpretation is consistent with the distribution of artificial fallout radionuclides Cs-137 and Pu-239 (H. D. Livingston, unpublished data), which show strong penetration to depths of 10-15 cm and smaller, but measurable, levels down to $20 \mathrm{~cm}$.

Goldberg and Koide (1962) have constructed a model describing the depth distribution of a radioactive tracer with constant input, which allows for uniform mixing from the surface down to some finite depth in the sediment. Rates of mixing are expressed mathematically as a diffusion coefficient, $D$. We have attempted to apply this model to our $\mathrm{Pb}-210$ data by taking $12 \mathrm{~cm}$ at the depth of mixing and $\mathrm{a}$. $\mathrm{Pb}-210$ delivery rate of $0.71 \mathrm{dpm} \mathrm{cm}^{-2} \mathrm{yr}^{-1}$ (Obtanined by integrating excess $\mathrm{Pb}-210$ over the length of the core). The model equations predict a concave upward curvature in the upper part of the plot, which is not followed by our data points. The best fit we could obtain would indicate a mixing coefficient, $D$, of about $2 \mathrm{~cm}^{2} \mathrm{yr}^{-1}\left(6 \times 10^{-8} \mathrm{~cm}^{2}\right.$ $\sec ^{-1}$ ). 
We are presently analyzing a second core from this area with samples taken at $1 \mathrm{~cm}$ intervals in order to improve our resolution, especially about the $12 \mathrm{~cm}$ break, which is more likely a region of continuous transition. Our data will then be used with a more realistic model that allows for changes in the rate $\hat{i}$ of mixing with depth ( $T$. Goreau, unpublished manuscript).

If we take the $12 \mathrm{~cm}$ "break" as an effective lower limit to disturbance by mixing, we may consider the slope of the lower portion of the curve as representing the true sedimentation rate: in this case about $0.1 \mathrm{~cm} \mathrm{yr}^{-1}$. More detailed analyses will allow us to determine whether a truly linear. region exists at depth. It is worth noting that, had the sedimentation rate been much lower, or the penetration by mixing deeper, the $\mathrm{Pb}-210$ profile would be completely dominated by mixing effects, and strict application of Equation (6) would lead to erroneously high sedimentation rates. For higher sedimentation rates or shallower mixing depths, mixing effects would be minimal. Evidently conditions in Buzzards Bay are such that both sedimentation rates and mixing rates can be studied by the $\mathrm{Pb}-210$ method. 


\section{REFERENCES}

Broecker, W. S., A. Kaufman and R. Trier (1973). The residence time of thorium in surface seawater and its implications regarding the fate of reactive pollutants, Earth Planet. Sci. Lett., 20, 35-44.

Craig, H., S. Krishnaswami and B.L.K. Somayaju7u (1973): $\mathrm{Pb}^{210}-\mathrm{Ra}^{226}$ : radioactive disequilibrium in the deep sea, Earth Planet. Sci. Lett., 17, 295-305.

Goldberg, E. D. (1954). Marine geochemistry I. Chemical scavengers of the sea, J.: Geol., 62, 249-265.

Goldberg, E. D. and M. Koide (1962). Geochronological studies of deep sea sediments by the ionium-thorium method, Geochim. Cosmochim. Acta, 26, 417-450.

Koide, M., A. Soutar and E. D. Goldberg (1972). Marine geochronology with $\mathrm{Pb}-210$, Earth Planet. Sci. Lett., 14, 442-446.

Krishnaswamy, S., D. Lal, J. M. Martin and M. Meybeck (1971). Geochronology of 1ake sediments, Earth Planet. Sci. Lett., 11, 407-414.

Krauskopf, K. B. (1956). Factors controlling the concentrations of thirteen rare metals in seawater, Geochim. Cosmochim. Acta, $\underline{9}, 1-32 B$.

Kuo, H. H. and G. Veronis (1973). The use of oxygen as a test for an abyssal circulation mode1, Deep Sea Res.. ?..., 871-8R8,

Lambert, G. and M. Nezami (1965). Importance des retombees seches dans le bilan du plomb 210, Ann. Geophysique, 21, 245-251. Matsumoto, E. (1975). ${ }^{234} \mathrm{Th}^{2}{ }^{238} \mathrm{U}$ radioactive disequilibrium in the surface Tayer of the ucean, Geochim. Cosmochim. Acta, 39, 205-212. 
Rama, M. Koide and E. D. Goldberg (1961). Lead-210 in natural waters, Science, 134, $98-99$.

Riley, G. A.,.H. Stommel and D. F. Bumpus (1949). Quantitative ecology of the plankton of the western North Atlantic, Bull. Bingham Oceanogr. $\operatorname{Col1}$, 12, 1-769.

Robbins, J. A. and D. N. Edgington (1975). Determination of recent sedimentation rates in Lake Michigan using $\mathrm{Pb}-210$ and $\mathrm{Cs}-137$, Geochim. Cosmochim. Acta, 39, 285-304.

Shannon, L. V., R. D. Cherry and M. J. Orren (1970). Polonium and lead-210 in the marine environment, Geochim. Cosmochim. Acta, 34;701-711. Spencer, D. W. (1974). The distribution of some chemical elements between dissolved and particulate phases in seawater, Report to AEC on Contract AT (11-1)-3566, 1973-1974, C00-3566-10.

Tatsumoto, M. and C. C. Patterson (1963). The concentration of common lead in seawater, in: Earth Sciences and Meteorites, North-Holland Publ. Co., Ams terdam, 74-89.

Turekian, K. K., D. P. Kharkar and J. Thompson (1974). Uranium and thorium decay serịes abundances in marine plankton, ARPA No: 1793.

Wust, G. (1964). Stratification and Circulation in the Antillean-Caribbean Basins, Columbia University Press, 201 pp. 
STUDIES IN THE GULF OF MAINE

At the time of writing this report, we have completed the proposed cruise of the R/V ATLANTIS II to the Gulf of Maine during January 4-11, 1975. The hydrographic data from this cruise has been partially reduced and assembled and some preliminary interpretations will be given. A complete report will be issued later. During the cruise, which concentrated in the area of the Murray-Wilkinson Basin, we occupied 35 stations at the locations shown, on Figure 4. Work conducted during the cruise consisted of continuous salinity and temperature profiling at all stations using a C.T.D. At selected stations, we ran nephelometer profiles and collected samples for on-board measurement of salinity, temperature, dissolved oxygen, phosphate and silicate. Samples collected for laboratory processing included particulate matter for both major and trace element and $\mathrm{Pb}^{210}-\mathrm{Po}^{210}$ studies, water samples for $\mathrm{Pb}^{210}-\mathrm{Po}^{210}$ studies. Samples were also collected by Dr. V. T. Bowen for determination of $\mathrm{Sr}^{90}, \mathrm{Cs}^{137}$ and $\mathrm{Pu}^{239}$. A total of 7 large diameter cores were collected for fallout radioisotope and stable element studies.

The Murray-Wilkinson Basin was chosen for study because of its relatively stable deep water structure. Deep water in the Gulf of Maine originates in intermittent flows through the Northeast Channel and is principally Slope Water and Coastal Water of Labrador origin. The deep waler temperature and salinity of the Gulf of Maine responds to variations in the composition and relative proportions of these waters entering the Northeast Channel. Colton (1968) has shown that the Murray-Wilkinson Basin bottom water is 
least affected by these intermittent variations and colton and Stoddard (1973) have shown that the average bottom water temperature encountered in the deep part of the Murray-Wilkinson Basin tend to be relatively constant.

The Murray-WiTkinson Basin is an elongated (NNW-SSE) depression in the sea floor, about 80 miles long, which reaches a maximum depth of about 285 meters. It is open to the east and southeast, where the Rodgers passage and a passage to the Franklin Basin form sills of about 185 meters depth. To the north, a channel connected to the Platts Basin has a sill of about 170 meters. The Franklin Basin is a southwestward extension of the Georges Basin and is connected to the open North Atlantic Ocean with sills deeper than $200 \mathrm{~m}$. The deep part of the basin is split by the Wilkinson divide, a ridge of about 250 meters depth which separates the Wilkinson and Murray Basins. Hydrographic data collected during ATLANTIS II cruise, 86 , is summarized in the appendices. Appendix 1 lists station locations and casts, Appendix 2 gives a selection of data from the CTD, Appendix 3 gives discrete sample data and Appendix 4 gives particulate matter concentrations.

HYDROGRAPHIC DATA

Examination of the salinity and temperature data show that deep water. conditions existing now in the Gulf of Maine are considerably different from those of the previous decades. A succession of mild winters, particularly 1973-1974 and 1974-1975 has led to warmer water compared with earlier years. 
Table 1 compares the average temperature at five deep water stations in January 1975 with the range found during the first three months of the year in the years 1920 to 1970. Above 100 meters the water is warmer than the maximum temperature observed during this period, while below $100 \mathrm{~m}$ the current temperature is close to the maximum observed historically. The salinity and temperature distributions along the sections identified $A-A^{1}, B-B^{1}$ and $C-C^{1}$ in Figure 4 are given in Figures 5 to 10 . A composite plot of potential temperature versus salinity is given in Figure 11 and this shows that with the exception of three of the most easterly stations, there is a very limited vertical range in temperature (between about $6.6^{\circ} \mathrm{C}$ and $\left.7.8^{\circ} \mathrm{C}\right)$ and that most stations are characterized by a major inversion in the temperature profile. Surface water, with a density of about $26.10 \sigma \tau$ has a range of temperature from about $6.98^{\circ} \mathrm{C}$ to $7.70^{\circ} \mathrm{C}$ and a salinity range from $33.165 \%$ to $33.402 \%$. Figure 12. shows that the warmer, saltier surface water exists in isolated lobes that are being eroded by the colder fresher water contained in a major anti-cyclonic gyre in the Gulf of Maine. The small arrows on Figure 12 illustrate the direction and strength of surface currents interpreted from a leeway analys is of the ATLANTIS II (R. Miller, 1975) during the period January 4-11, 1975. The two easternmost stations (2141 and 2142) have the warmest surface water and mid-water warm cores that reach temperatures of $8.69^{\circ} \mathrm{C}$. These stations are closer to the central region of the Gulf of Maine and probably represent a residual of "summer" water that has been less well mixed with the colder fresher water in the major gyre. A "residual" warm water core is present at about $130 \mathrm{~m}$ depth in 211 of the stations 
(see Figures 5,7 and 9). In the deep water a major feature is a cold water core which is most pronounced in the southern regions of the basin. At stations 2144,2149 and 2154 , temperature minima of $6.60^{\circ} \mathrm{C}, 6.77^{\circ} \mathrm{C}$ and $6.65^{\circ} \mathrm{C}$ occur respectively at depths of $156 \mathrm{~m}, 164 \mathrm{~m}$ and $160 \mathrm{~m}$, with salinities of $33.657 \%, 33.798 \%$ and $33.700 \%$. This cold layer persists throughout the basin at about 180 to $200 \mathrm{~m}$ depth but is at a maximum thickness at the southern end. Figure 9 shows that at the northern end of the basin, the cold water core is thickest toward the western margin and a general rise of the isotherms takes place on the western slope. This suggests that the cold water core may be part of the major gyre and represent a mixture of Labrador Coastal Water and Slope Water advecting in from the Franklin Basin. Although a narrow passage with a depth of about $185 \mathrm{~m}$ connects the wilkinson and Franklin Basins, there is a very broad sill with a depth of about $160 \mathrm{~m}$ corresponding to the depth of the cold water core in the south and east.

Below 200m, in the deepest portions of the basin, the bottom water has temperatures from $7.20^{\circ} \mathrm{C}$ to $7.35^{\circ} \mathrm{C}$ and salinities from $34.080 \%$ 。 to $34.165 \%$. Bottom water temperatures of about $7.2^{\circ} \mathrm{C}$ are principally restricted to the Wilkinson Basin. In the Murray Basin, such temperatures occur only in the very deepest portions toward the snuthern end. This is undoubtcdly due to the more extensive mixing with the cold water core immediately above and the presence of the Wilkinson divide which restricts the circulation of the bottom water. Station 2142 is unique in having bottom water temperatures of $7.85^{\circ} \mathrm{C}$ at 205 meters with salinities of $34.270 \%$. This salty warm water is probably 
Connected to the deep warm water core of station 2141 and probably represents deep water from the Northeast Channel of predominantly Slope Water origin with a salinity of about $35 \%$ and temperature of about $9^{\circ} \mathrm{C}$ (McLellan, 1957).

The relationships between salinity and both dissolved oxygen and silicate are shown in Figure 13. Each relationship may be described by essentially three linear sections representative of 1) mixing between the high oxygen and low silica surface water and warm mid-water core of salinity. $33.5 \%$, 2) mixing between the warm water core and the cold water core of salinity $33.75 \%$, where a marked decrease in oxygen and increase in silicate are observed and 3) mixing between the cold water core and the bottom water of slightly lower oxygen and higher silicate. The oxygen and silicate concentrations of the cold water core are consistent with its origin in a mixture of Labrador Coastal Water and Slope Water. The bottom water has lower oxygen and higher silicate than would be expected in either the Labrador Coastal Water or Slope Water and may indicate some in situ oxydation, during a relatively long residence time of the bottom water in the Gulf of Maine.

\section{DISTRIBUTION OF PARTICULATE MATTER}

Particulate matter samples were collected by direct filtration of sea water from 30 liter Niskins into evacuated glass carboys. This procedure was chosen in order to remove any risk of contamination of the sample during the intermediate pressure filtration storage tank that characterized our earlier procedures. The samples were collected on $47 \mathrm{~mm}$ preweighed Nuclepore filters with a pore diameter of $0.6 \mu$. The filters were loaded into the filter holders inside a clean glove box and after the filtration the holders were 
returned to the glove box where they were opened, the filters rinsed to remove sea salt and the filters were stored, sealed in clean individual polycarbonate boxes. After return to the laboratory, the filters were dried, equilibrated with the temperature and humidity conditions of the balance room and reweighed to determine the mass of suspended matter. The results of these operations are given in Appendix 4. As was expected from our earlier results (Spencer and Sachs, 1970; Spencer, et àl., 1971), the near surface concentrations of suspended matter were not markediy in . excess of the mid-water concentrations. This is typical of winter conditions. However, the near bottom nepheloid layer appears to be just as well developed as that observed in our earlier cruises during 1966-1968. Concentrations of suspended matter in near bottom samples were about $350 \mu \mathrm{g} / \mathrm{kg}$ in the northern end of the deep Murray-Wilkinson Basin and about $520 \mu \mathrm{g} / \mathrm{kg}$ toward the southern end:

At several stations nephelometer profiles were taken using a laser nephelometer designed and built by $P$. L. Sachs. Data on the in situ light scattering recorded by this instrument was telemetered to the surface acousticalily and recorded on a standard P.G.R.

The relationship between the nephelometer data and the particulate matter data for one station, 2138, are shown in Figure 14 and a selection of profiles showing the nephelometer and CTD data are given in Figures 15 to 19 .

Although not all of the data has been reduced, we are able at this time to make the following observations. 
The nephelometer data in the upper $50 \mathrm{~m}$. to $75 \mathrm{~m}$ of the water column is affected by scatter from ambient light and the results depend heavily upon whether the station was taken in daylight or darkness. In the deep water below $75 \mathrm{~m}$, a close relationship exists between light scattering values and particulate matter concentration.

An intensive near bottom nepheloid layer is a characteristic feature of all the deep stations. It is most intense in the southern part of the basin and its vertical extent depends upon the vertical density gradient and mixing between the bottom water and the overlying cold water core: In most cases, the density gradient established above the bottom water is sufficient to restrict the vertical diffusion of particles from the nepheloid layer and they rarely penetrate into the cold water core. Rather, at the southern end, where the cold water core initially penetrates into the basin, it is characterized by a mid-water particle maximum (see Figure 15 ) which is probably the result of passage of this cold water as bottom water across the broad sill from the Franklin Basin.

This mid-water maximum in the cold water core can be detected only about half way up the basin, being present at stations 2138 and 2151 but absent from stations 2133,2132 and 2122 . At the northern end of the basin; a separate mid-water particle maximum appears above the cold water core and may be the result of local bottom winnowing of sediments from the Cat Knol1 and Jeffreys Ledge area to the west of the basin. 
In general, the warm water at 100 to 130 meters is the most particle free water existing in the basin.

The distribution of the hydrographic data and the particulate matter appear to be consistent with the hypothesis that a fairly extensive resuspension of bottom sediments, probably principally by tidal currents, is taking place. This deep suspended matter diffuses vertically up to", but rarely penetrates the cold water core at $160-200 m$ depth and is thus largely retained within the basin. The cold water core appears to be carrying suspended sediment into the basin and other mid-water particle maxima suggest occasional contributions of sediment from the flanks of the bașin.

Our future work during the coming year wi11 complete the hydrographic interpretations and concentrate on the analysis of the particulate matter. and the $\mathrm{Pb}^{210}$ and $\mathrm{Po}^{210}$ distributions : 


\section{REFERENCES}

Colton, J. B. (1968). J. Fish. Res. Bd. Canada. 25 (11) 2427-2437.

Colton, J. B. and R. R. Stoddard (1973). NOAA Tech. Rep. INMFS Circ. 376.

McLellan, H. J. (1957). J. Fish. Res. Bd. Canada. 14(2) 213-239.

Miller, A. R. (1975). Unpublished manuscript.. W.H.O.I.

Spencer; D. W. and P. L. Sachs (1970). Marine Geology, 9, 117-136.

Spencer, D. W., P. G. Brewer. P. L. Sachs (1.971). Report to A.E.C. on Contract AT(30-1)-4150. A.E.C. Report No. NYO-4150-9. 


\section{FIGURE CAPTIONS}

Figures 1 and 2. $\mathrm{Pb}-210$ and $\mathrm{Po}-210$ profiles from the North Atiantic. Data points in parantheses were obtained from unfiltered water samples with particulate contributions estimated by interpolation.

Figure 3. Excess $\mathrm{Pb}-210$ distribution in Buzzards Bay sediment core: 41-29.0 N, 70-52.5 W. Apparent sedimentation rates from equation (6) are indicated.

Figure 4: Station locations.

Figure 5. Potentiat temperature vs. depth for section $A-A^{\prime}$

Figure 6. Salinity. vs." depth for section A-A'

Figure 7. Potential temperature vs. depth for section $B-B^{\prime}$

Figure 8. Salinity vs. depth for section $B^{-B^{\prime}}$

Figure 9. Potential temperature vs. depth for section $C^{-} C^{\prime}$

Figure 10. Salinity vs. depth for section $C^{-C^{\prime}}$

Figure 11. Composite plot of potential temperature vs. salinity

Figure 12. Plot of salinity at $10 \mathrm{~m}$, showing direction and strength of surface currents

Figure 13. Salinity vs. dissolved oxygen and silicate

Figure 14. Relationship of nephelometer data and particulate concentrations.

Figures 15-19. Nephelometer and CTD data vs. depth for Stations 2132, 2133 , 2135,2154 and 2155. 


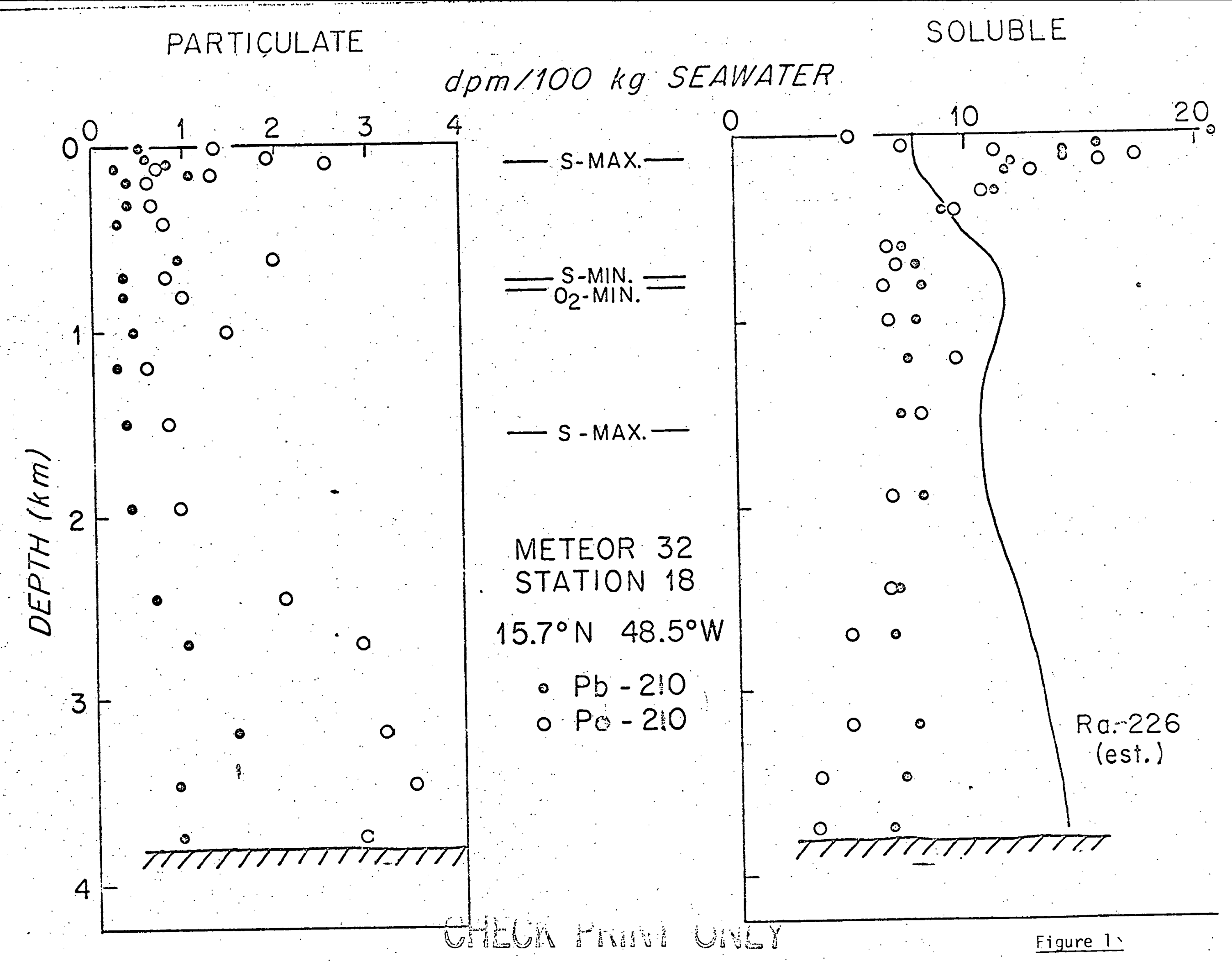




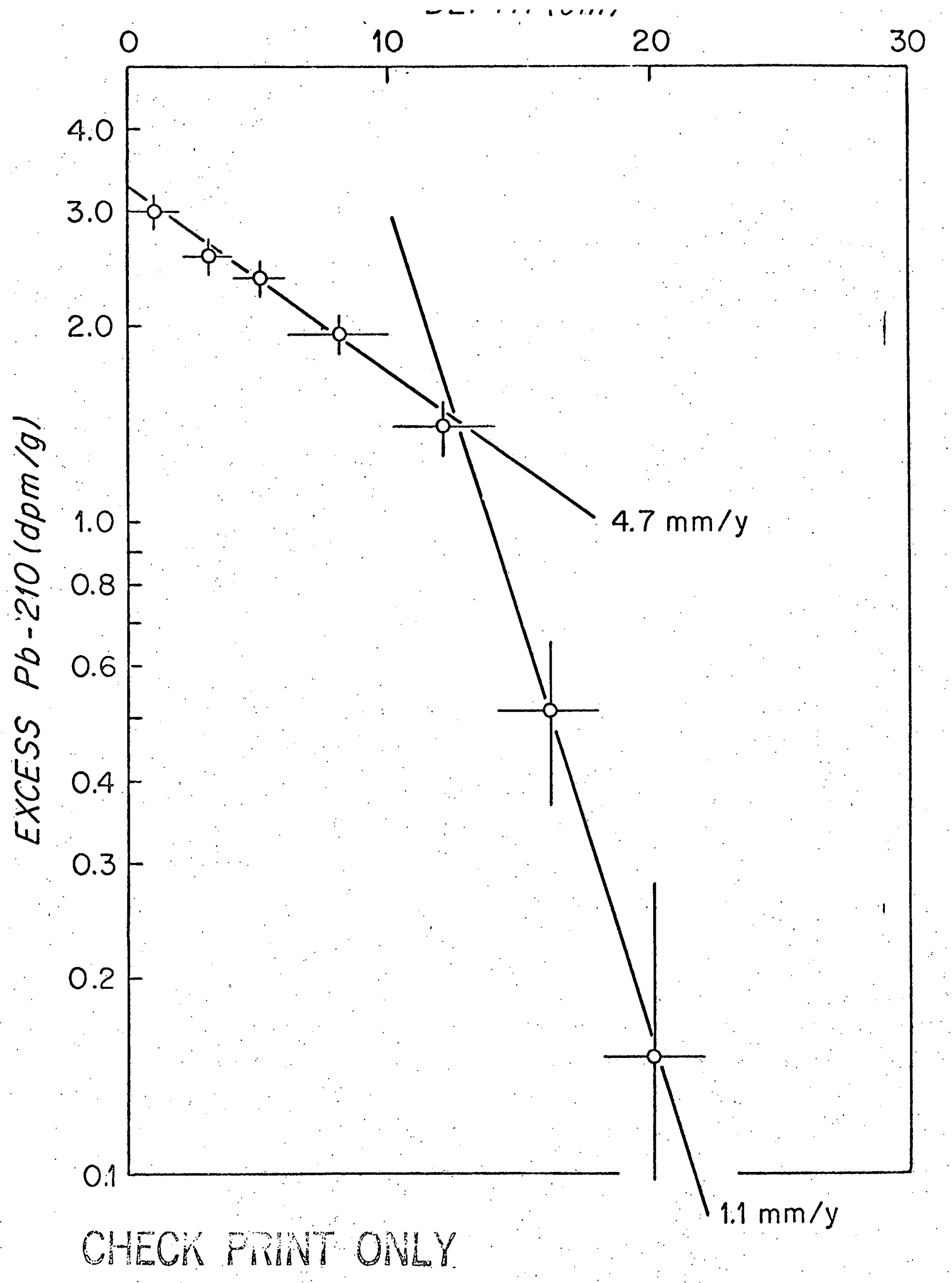

Figure 3 


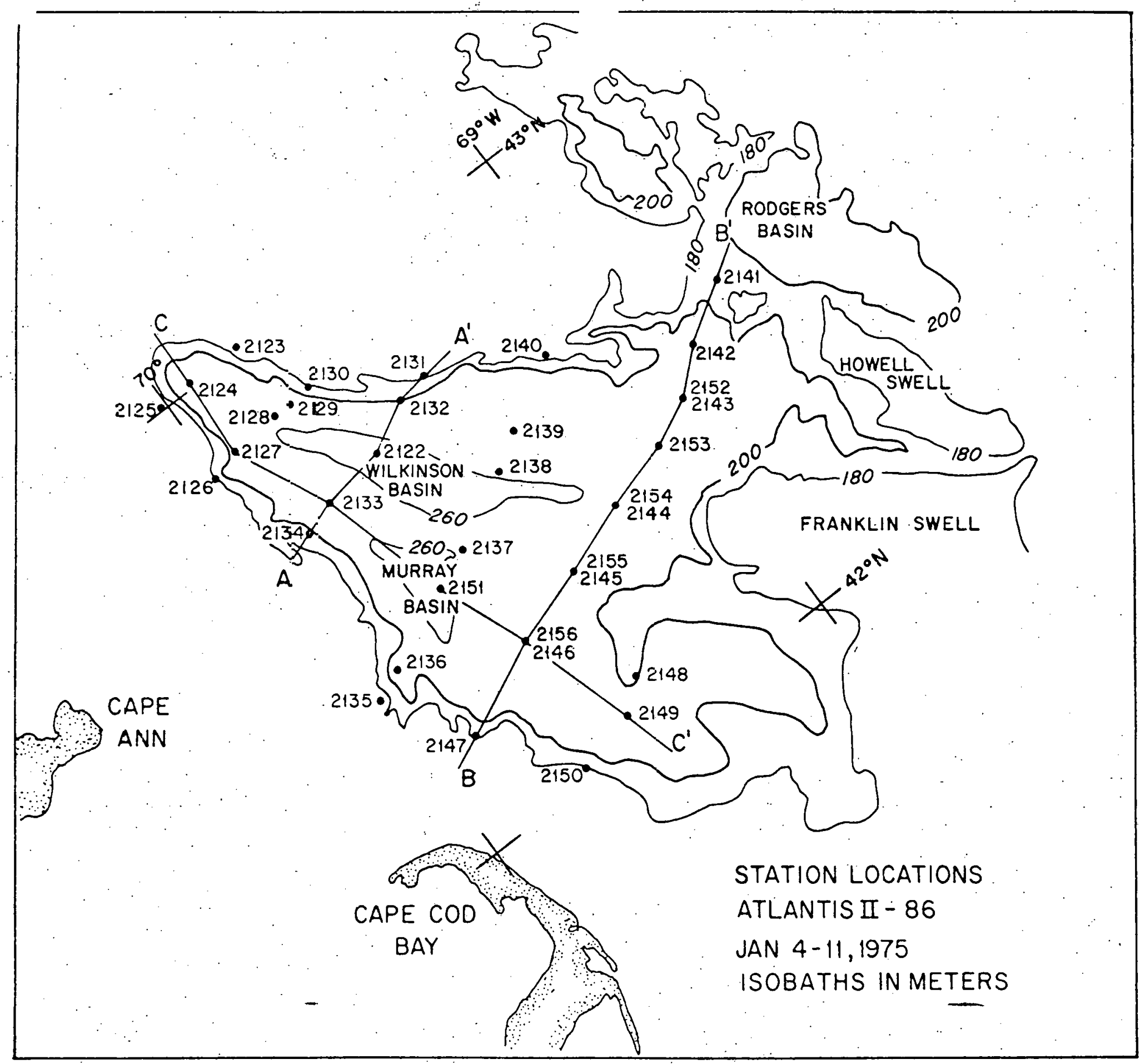

Fig. 4. Station Locations 


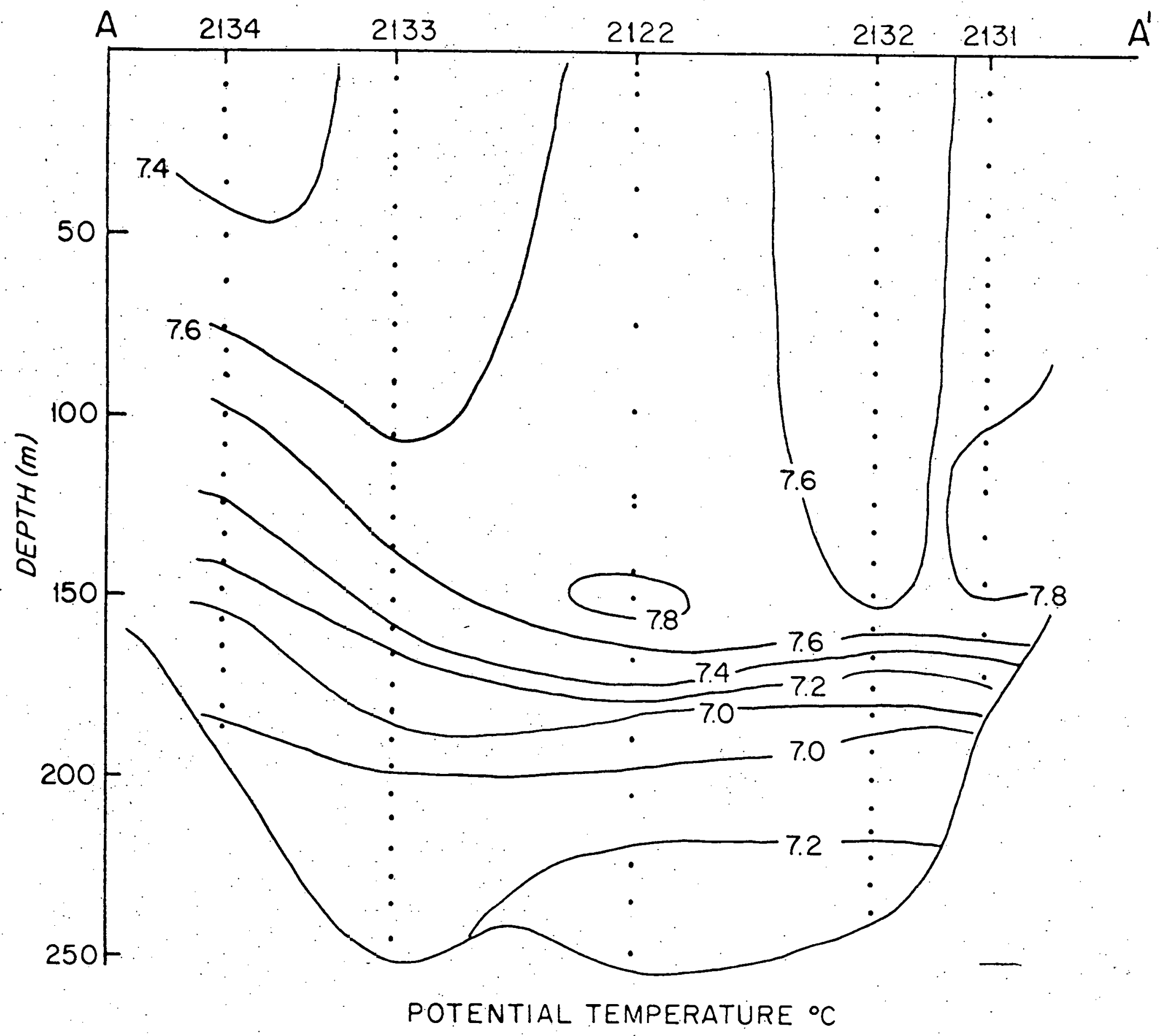

Fig. 5. Potential temperature vs. depth for section $A-A$ ' 


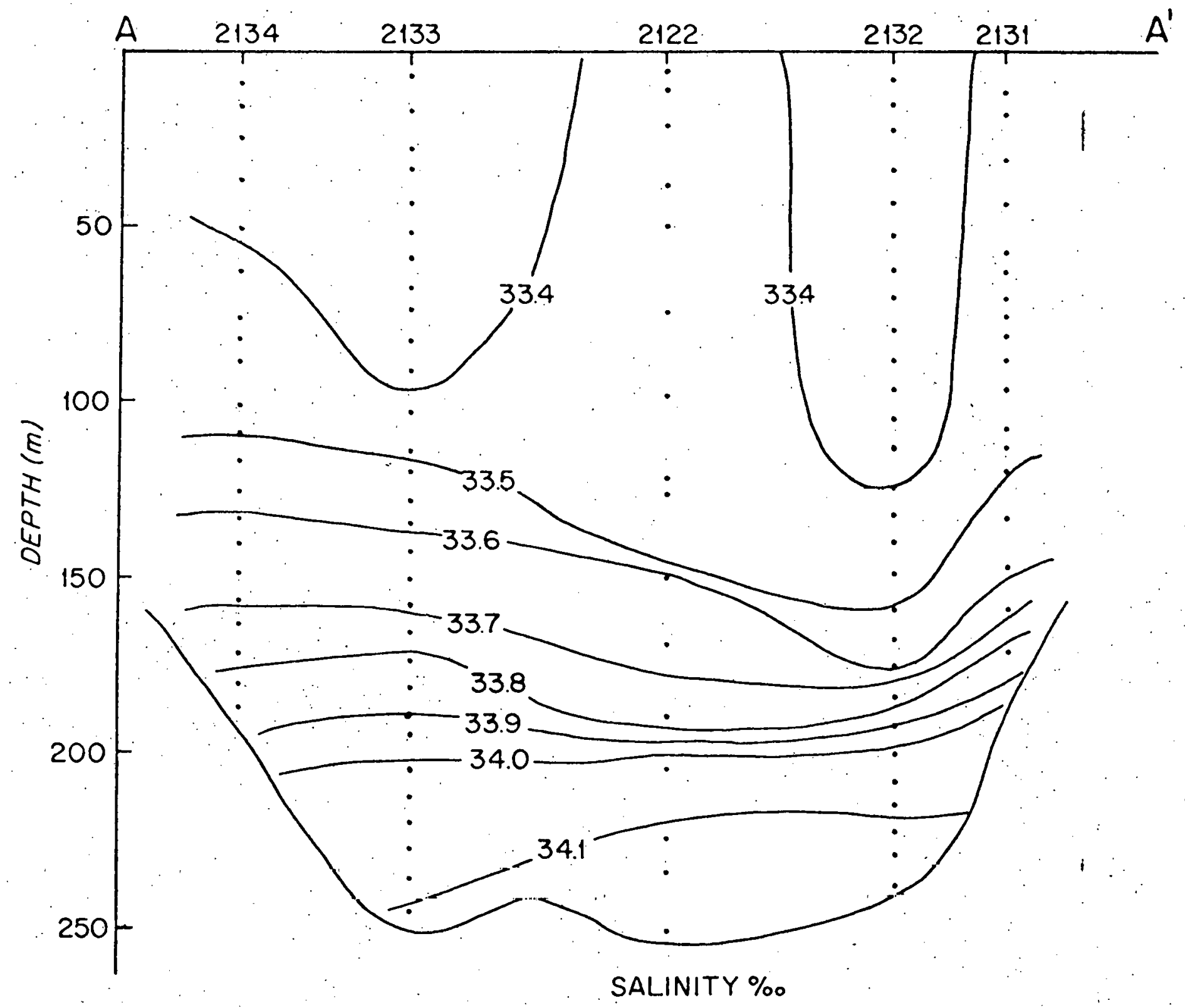

Fig. 6. Salinity vs. depth for section $A-A^{\prime}$. 


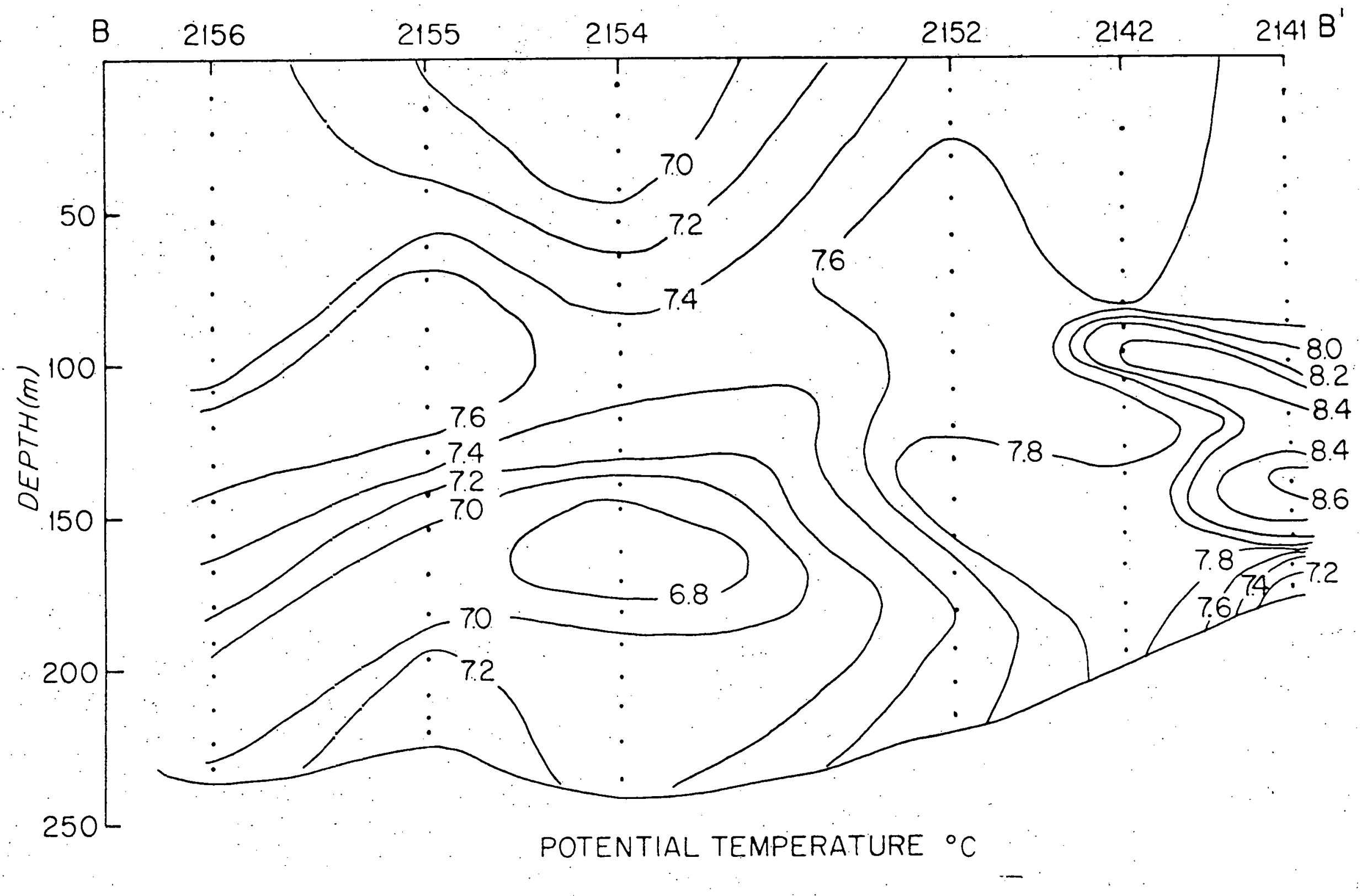

Fig. 7. Potential temperature vs. depth for section $B-B^{\prime}$ 


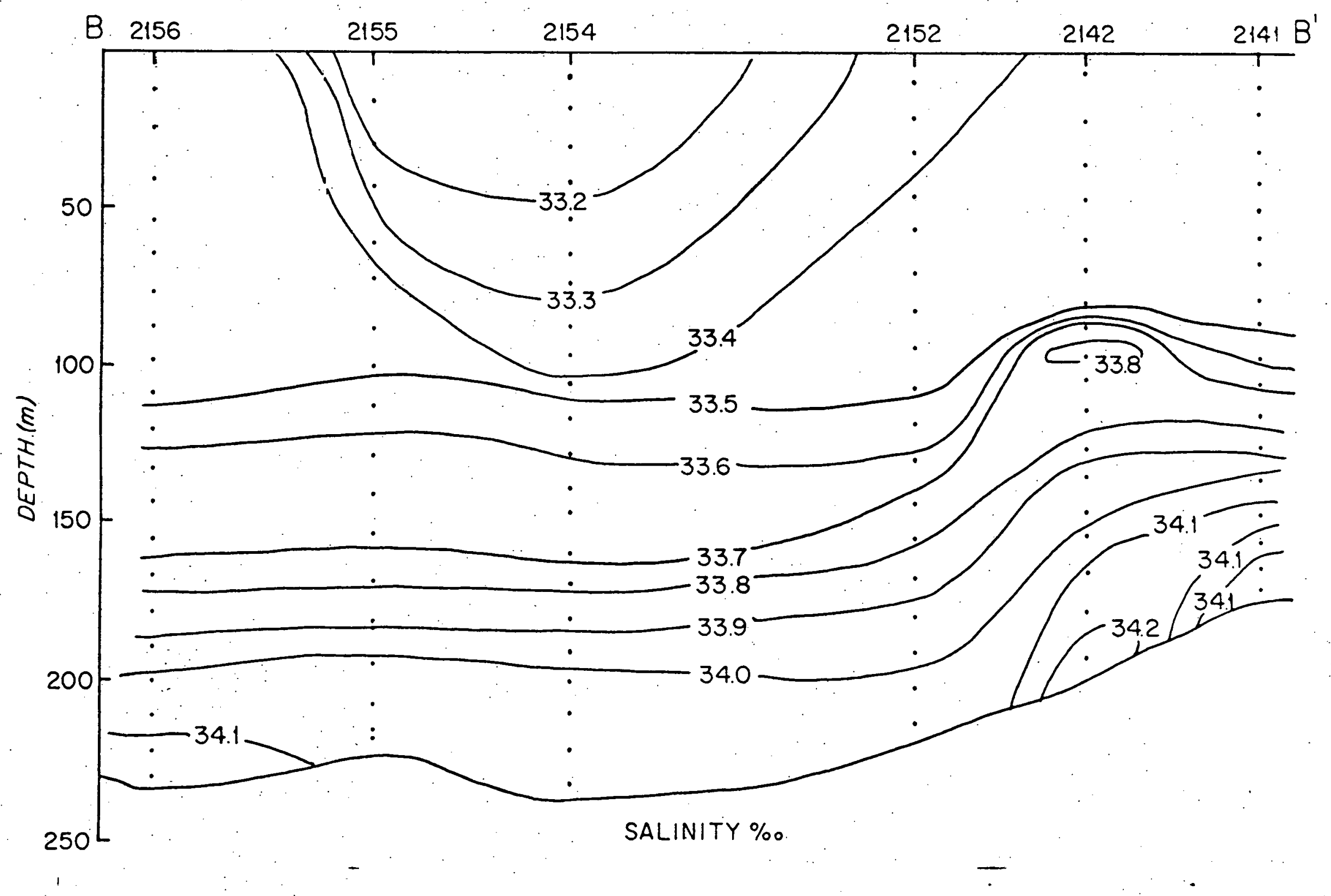

Fig.. 8. Salinity vs. depth for section $B-B^{\prime}$ 


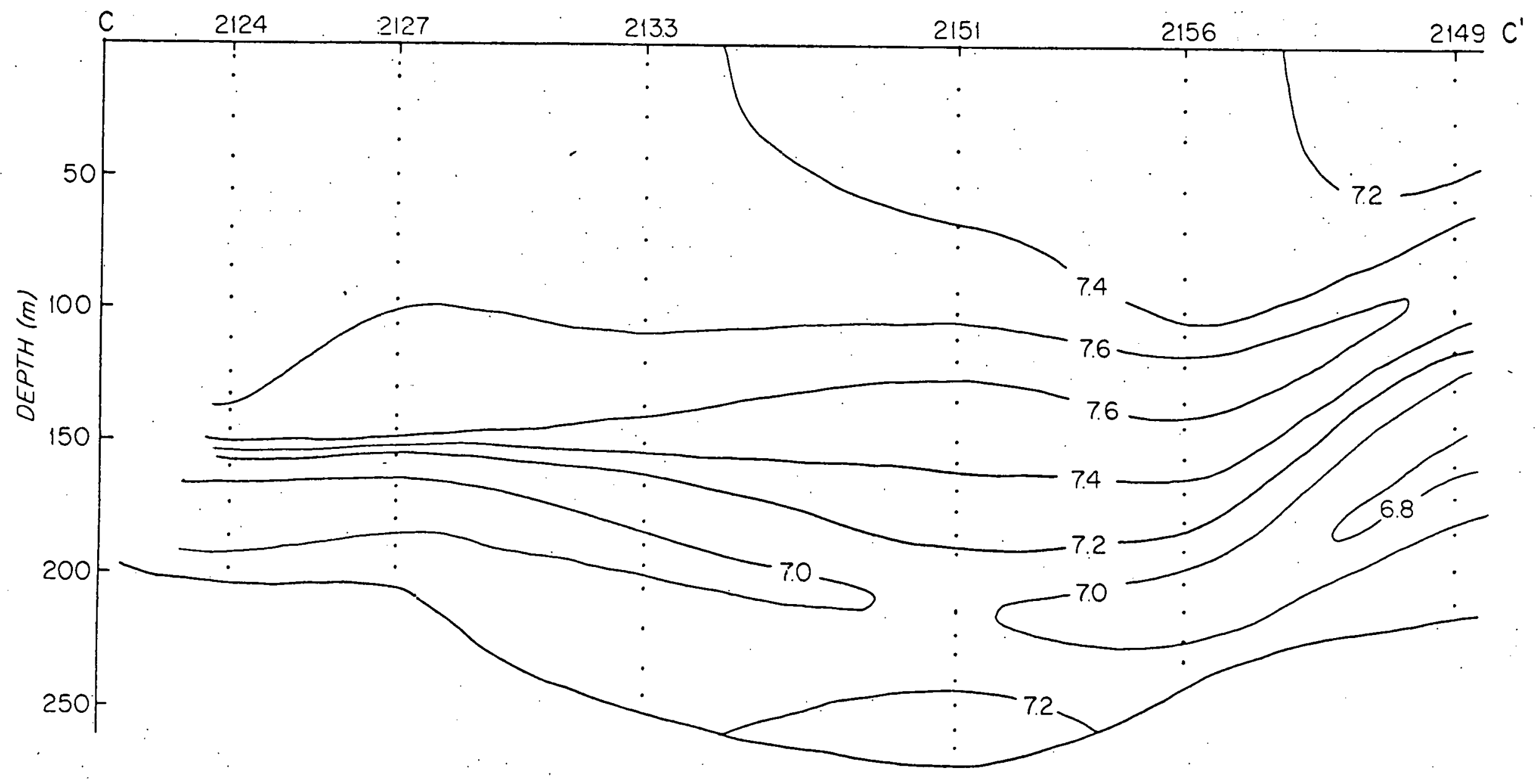

POTENTIAL TEMPERATURE ${ }^{\circ} \mathrm{C}$

=ig. 9. Potential temperature vs. depth for section C-C' 


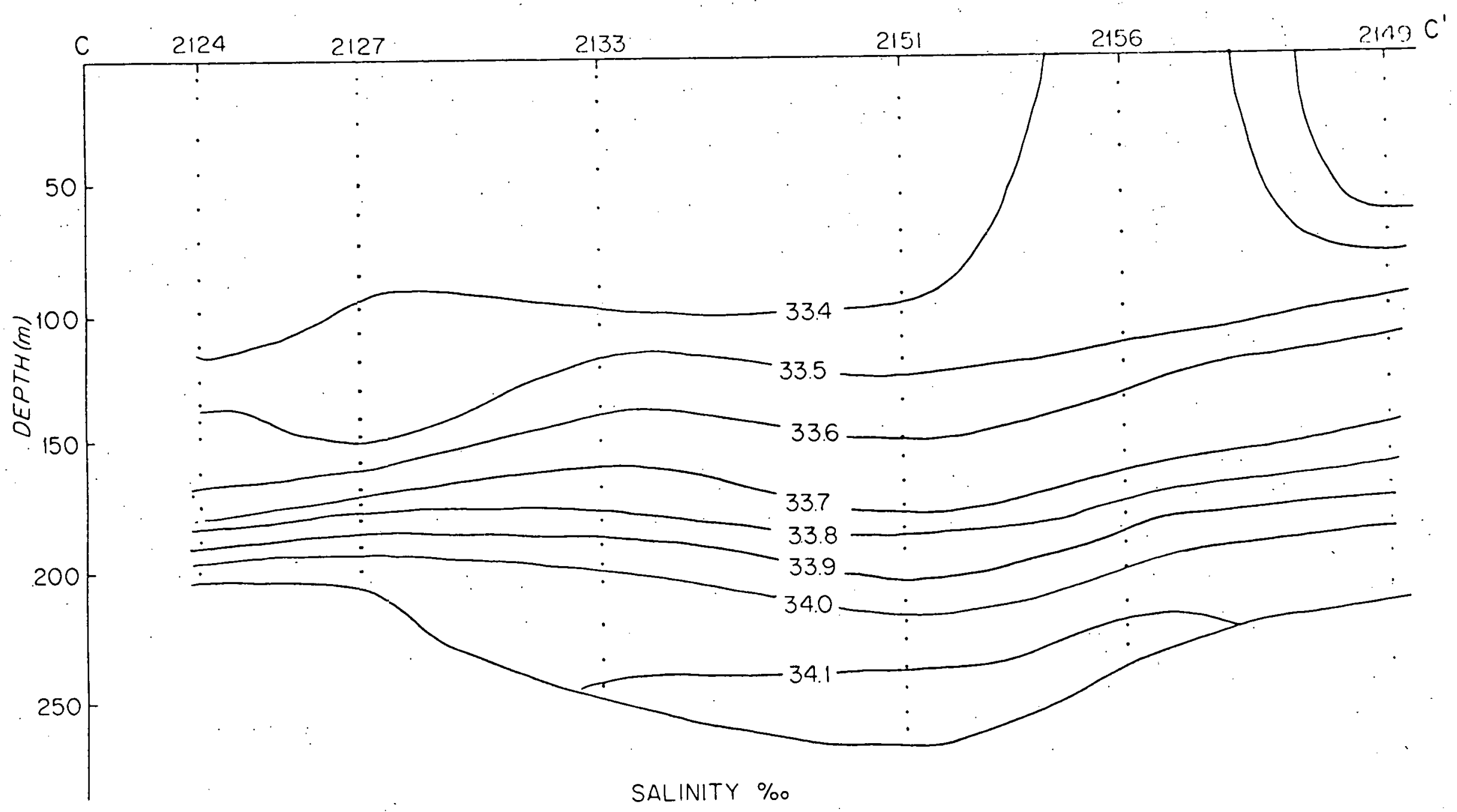

Fig. 10. Salinity vs, depth for section $C-C^{\prime}$ 


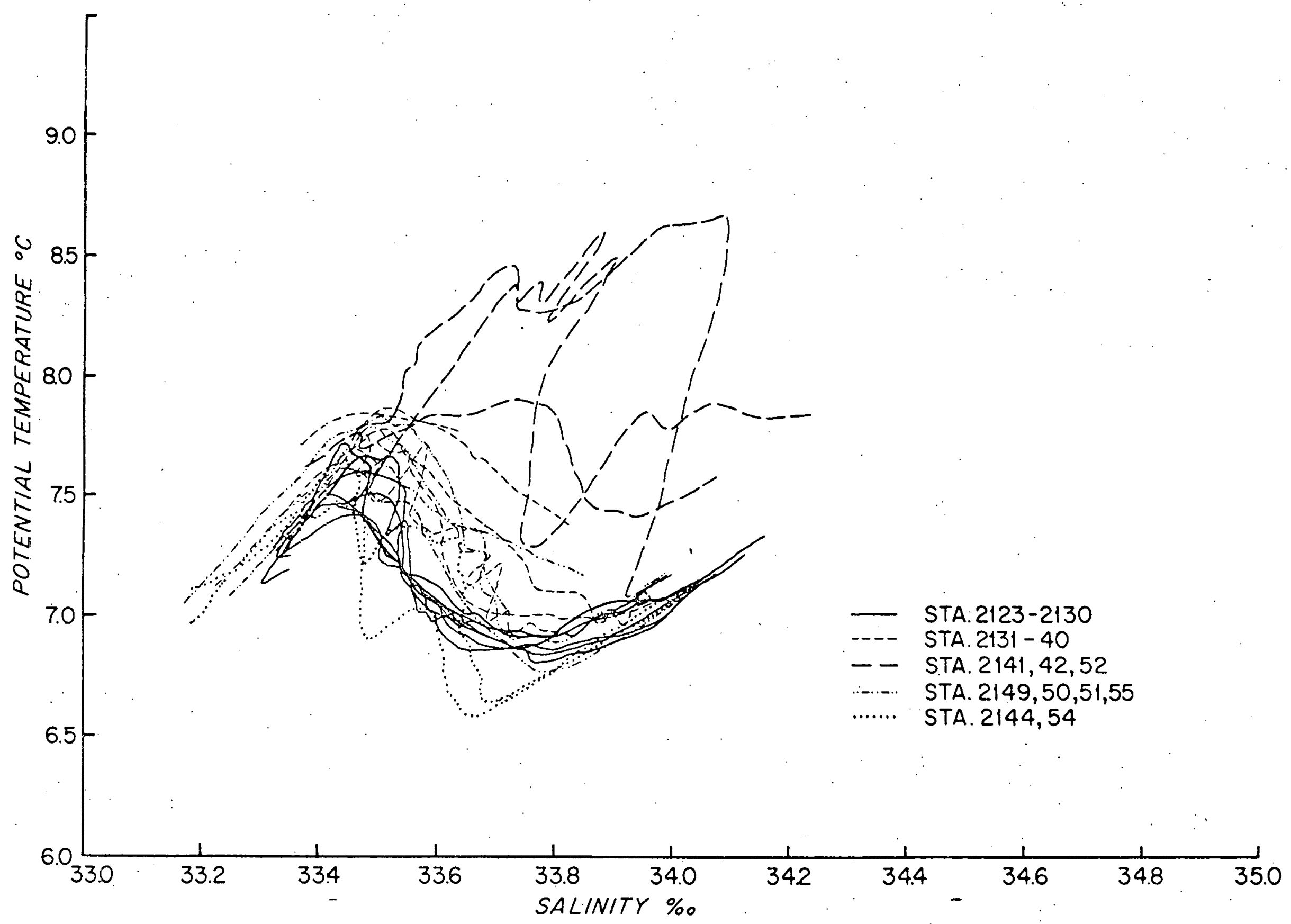

Fig. il. Composite plot of potential temperature vs. salinity 


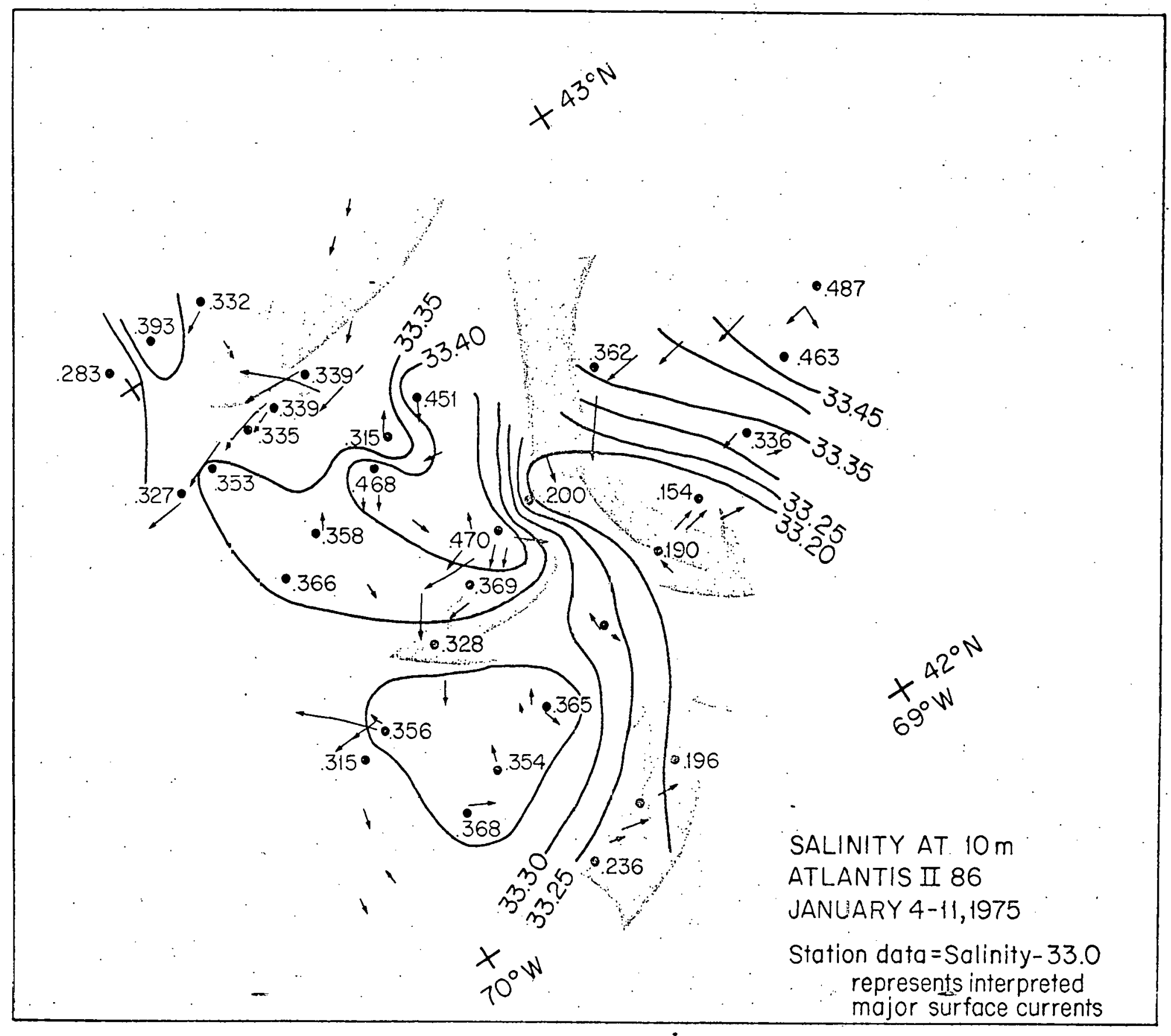

Fig. 12. Plot of salinity at $10 \mathrm{~m}$, showing direction and strength of surface currents 


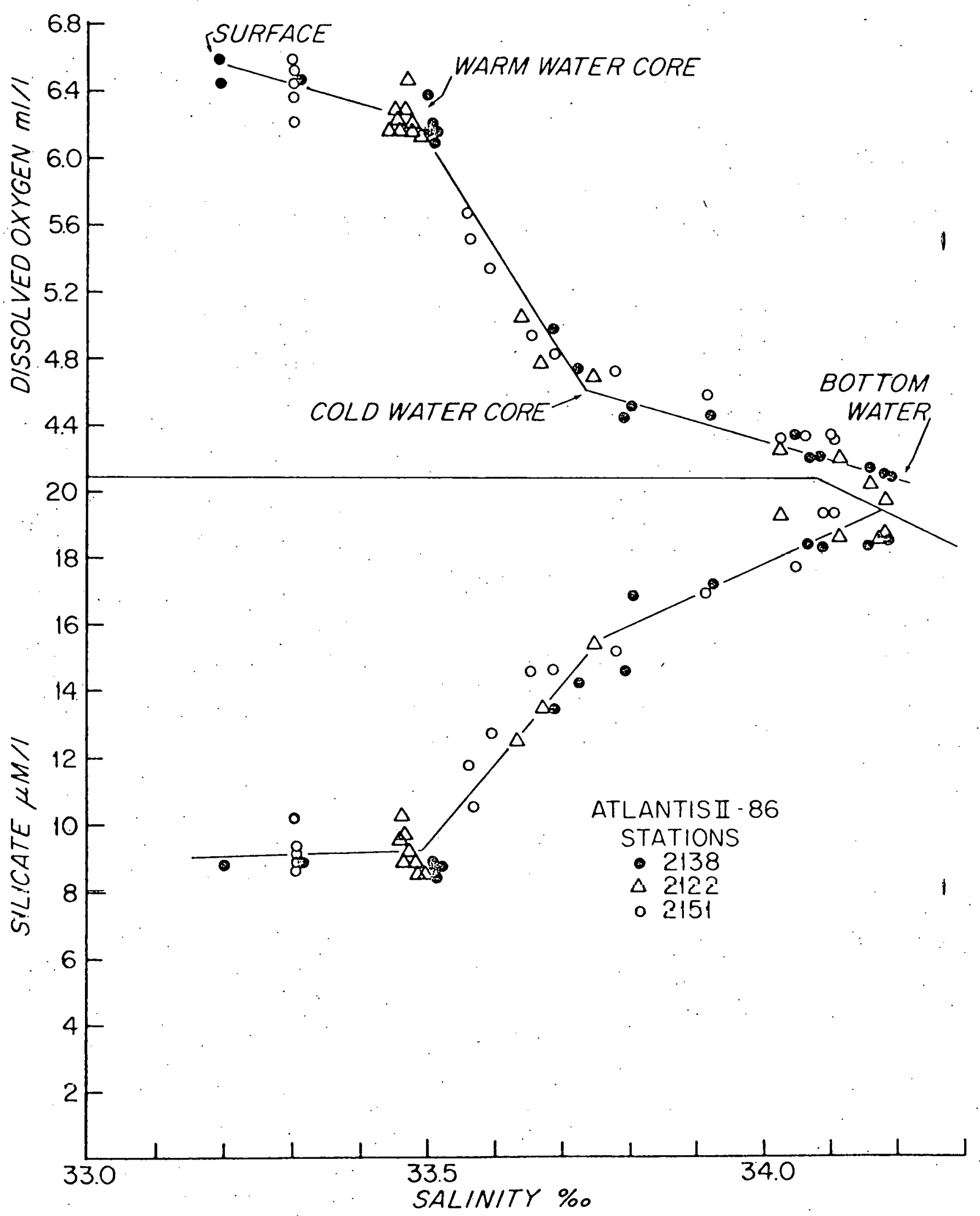

Fig. 13. Salinity vs. dissolved oxygen and silicate 


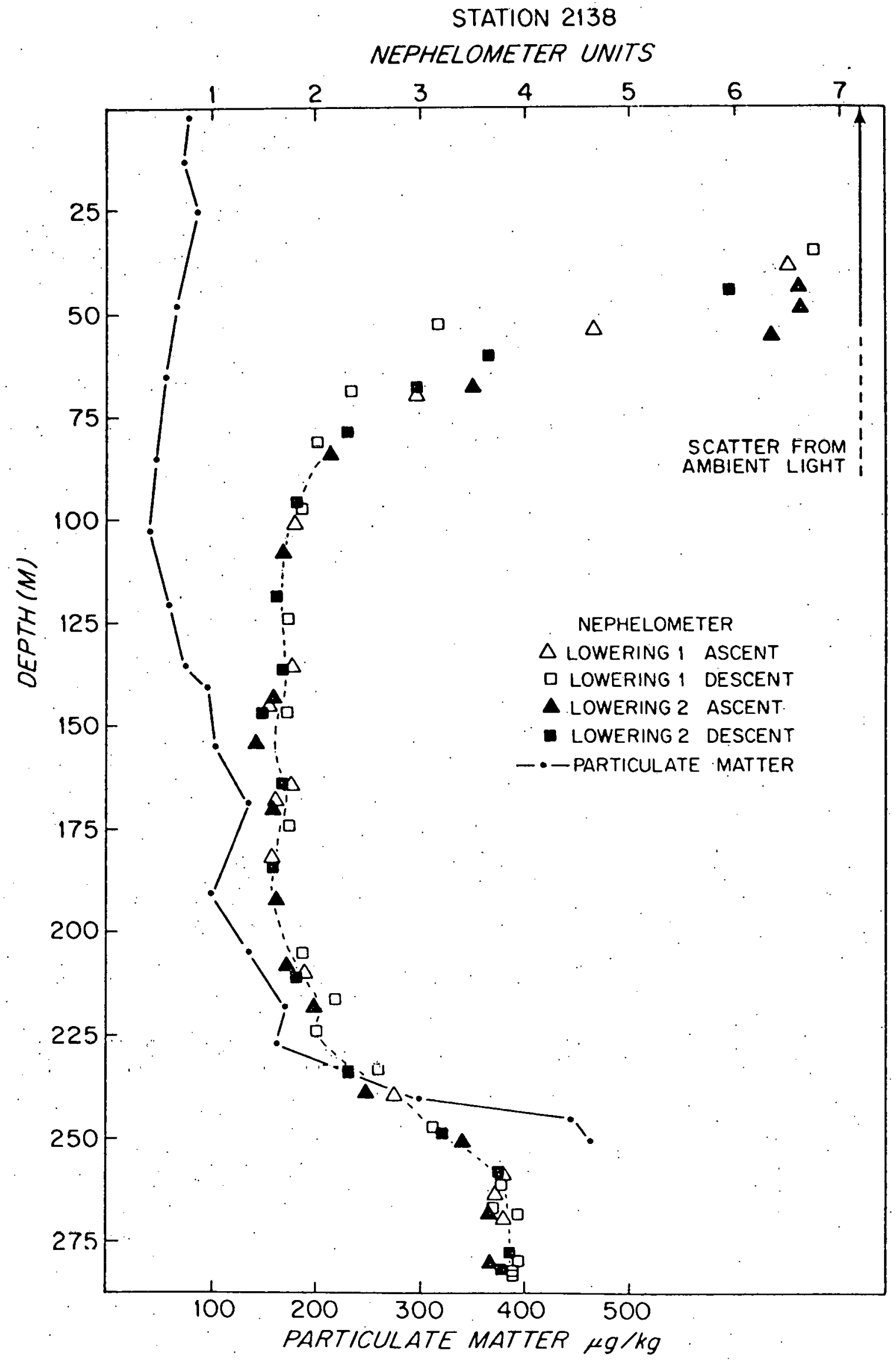

Fig. 14. Relationship of nephelometer data and particulate concentrations 


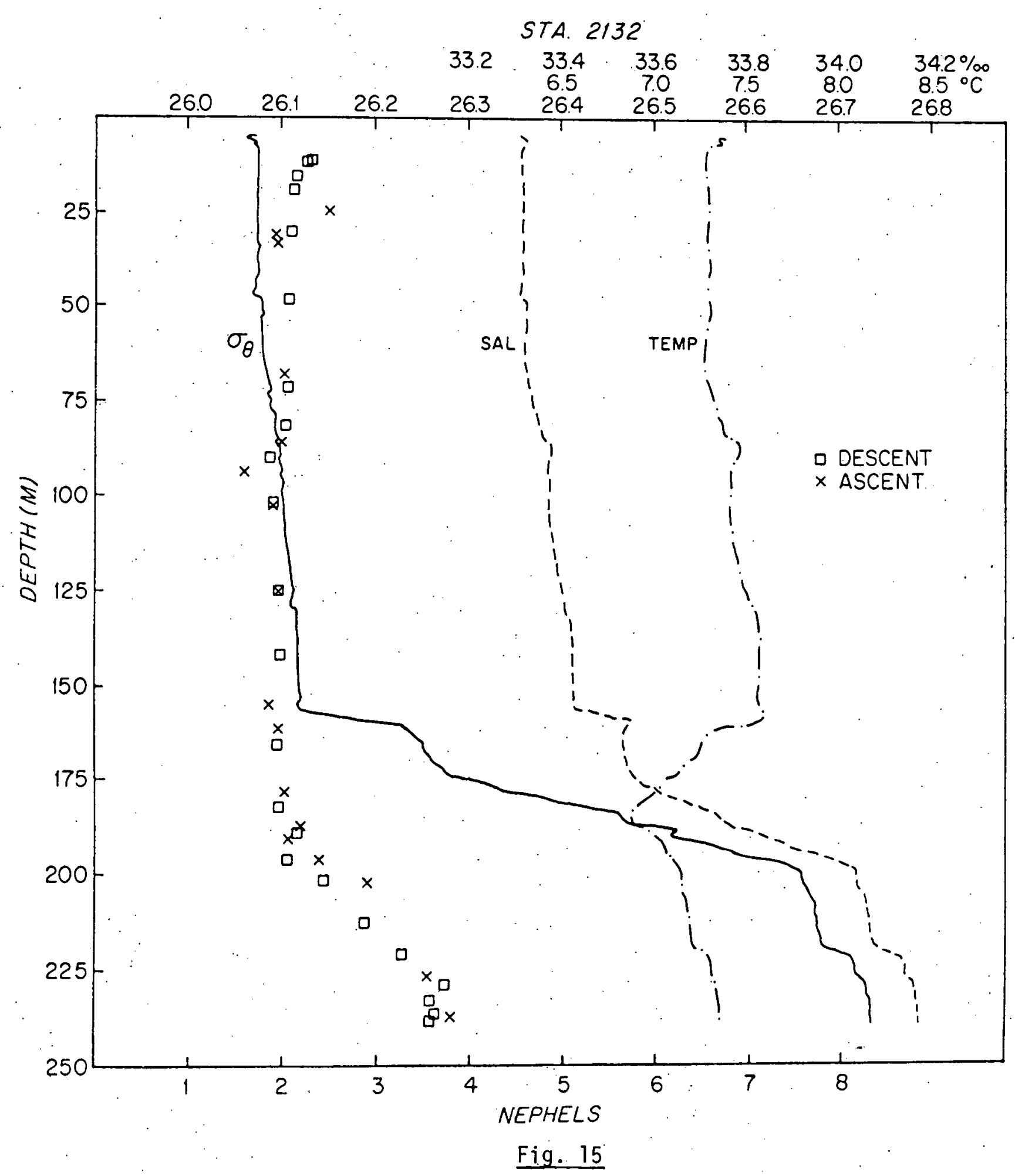




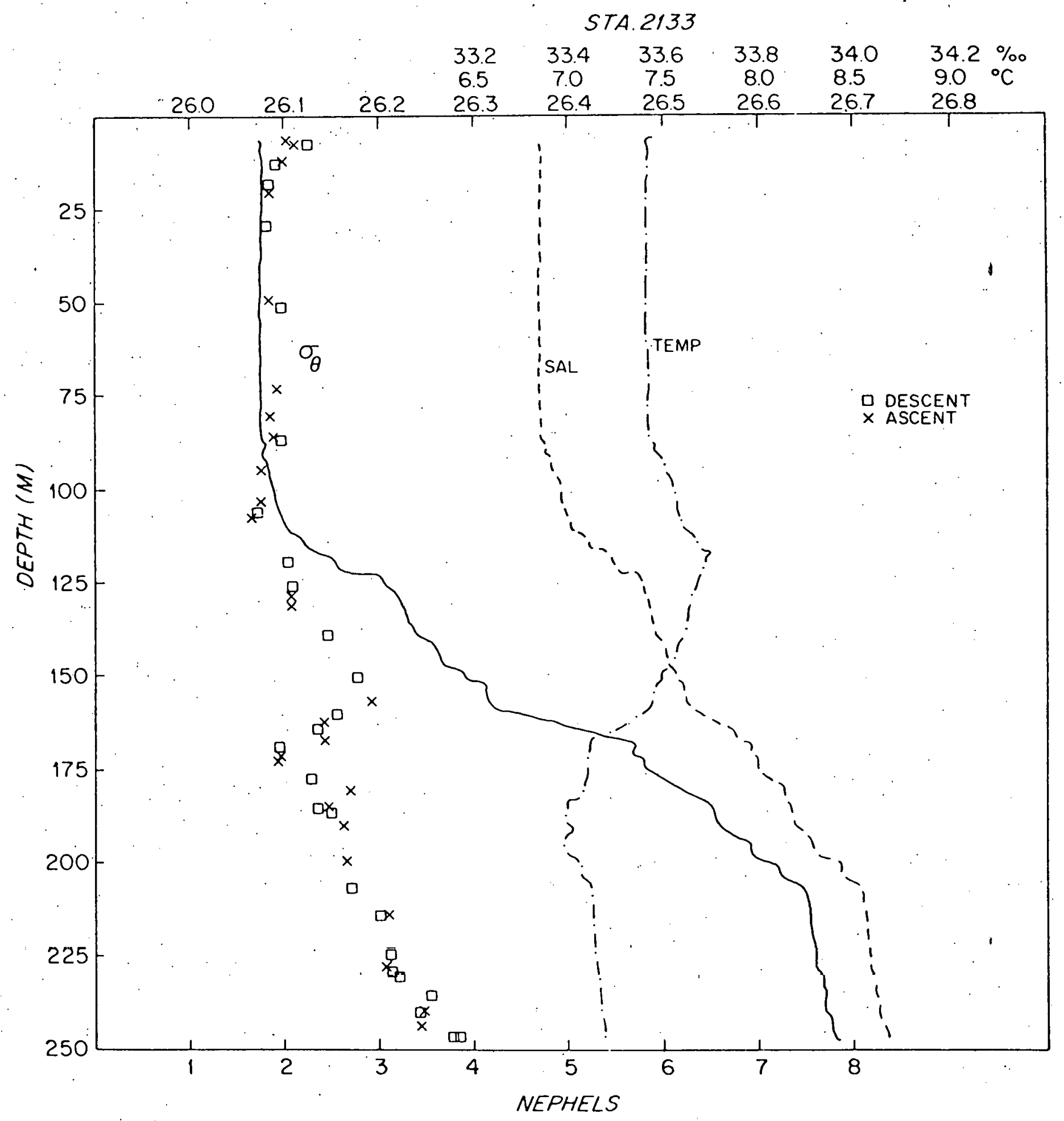

Fig. 16 


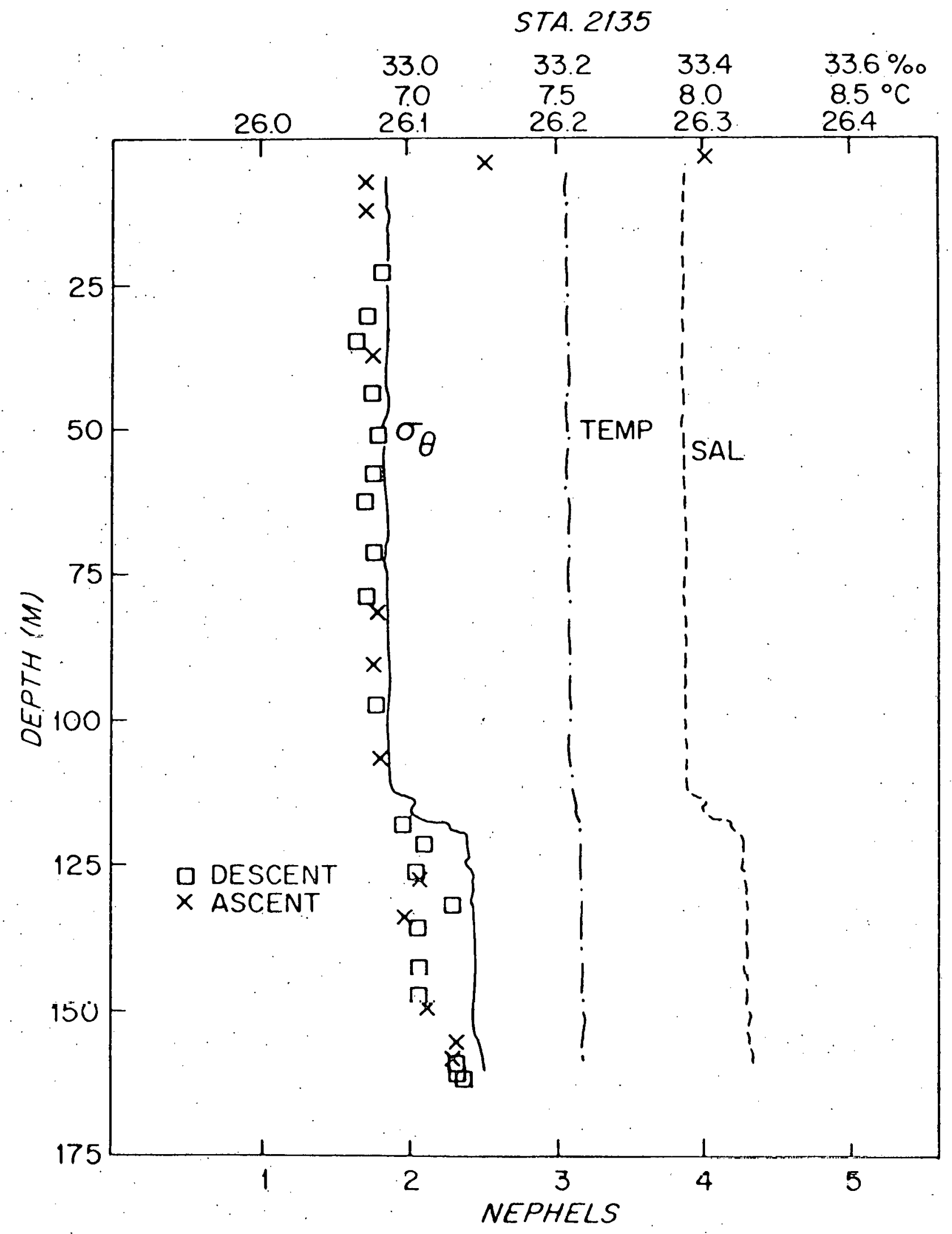

Fig. 17 


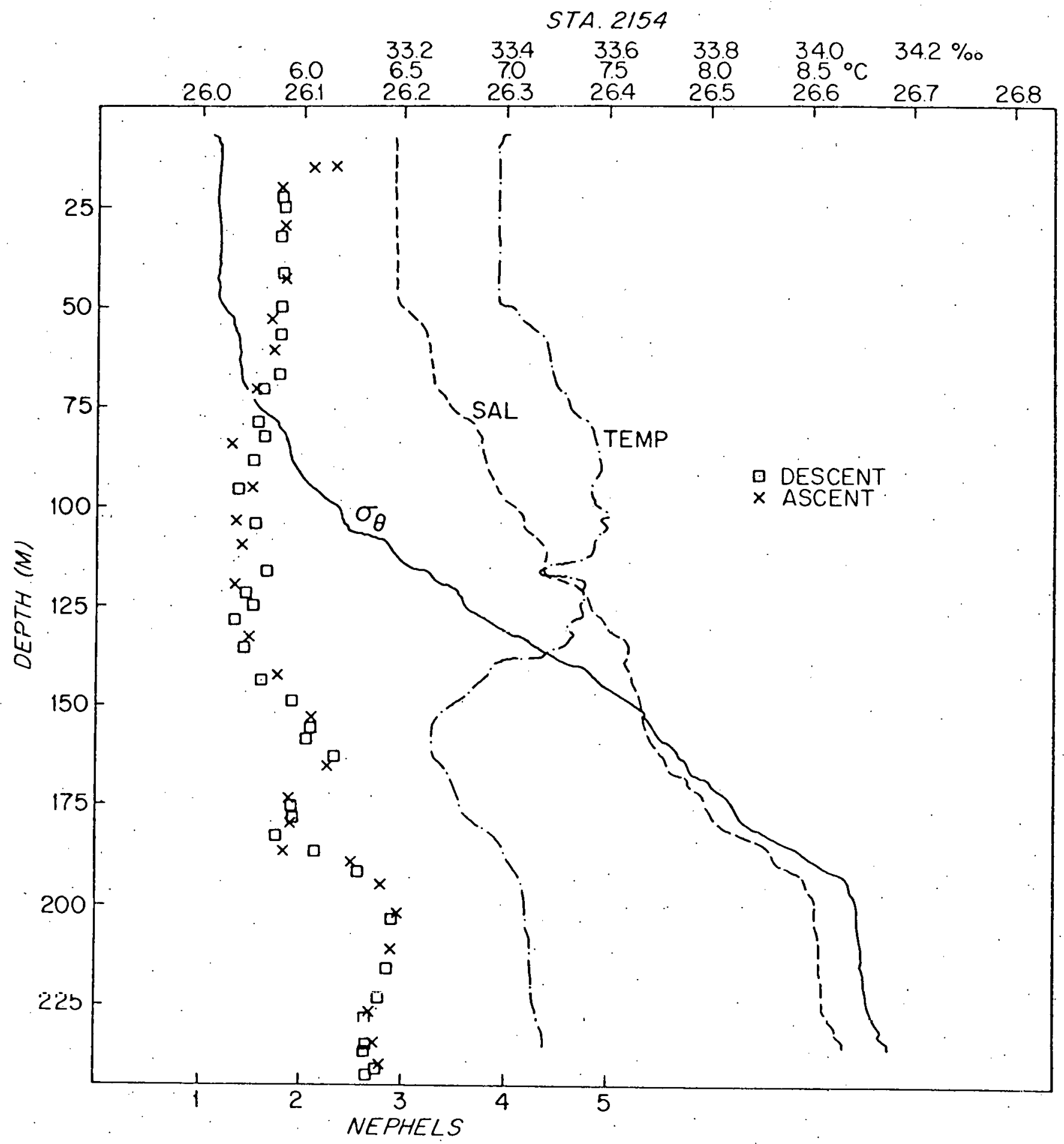

Fig. 18 


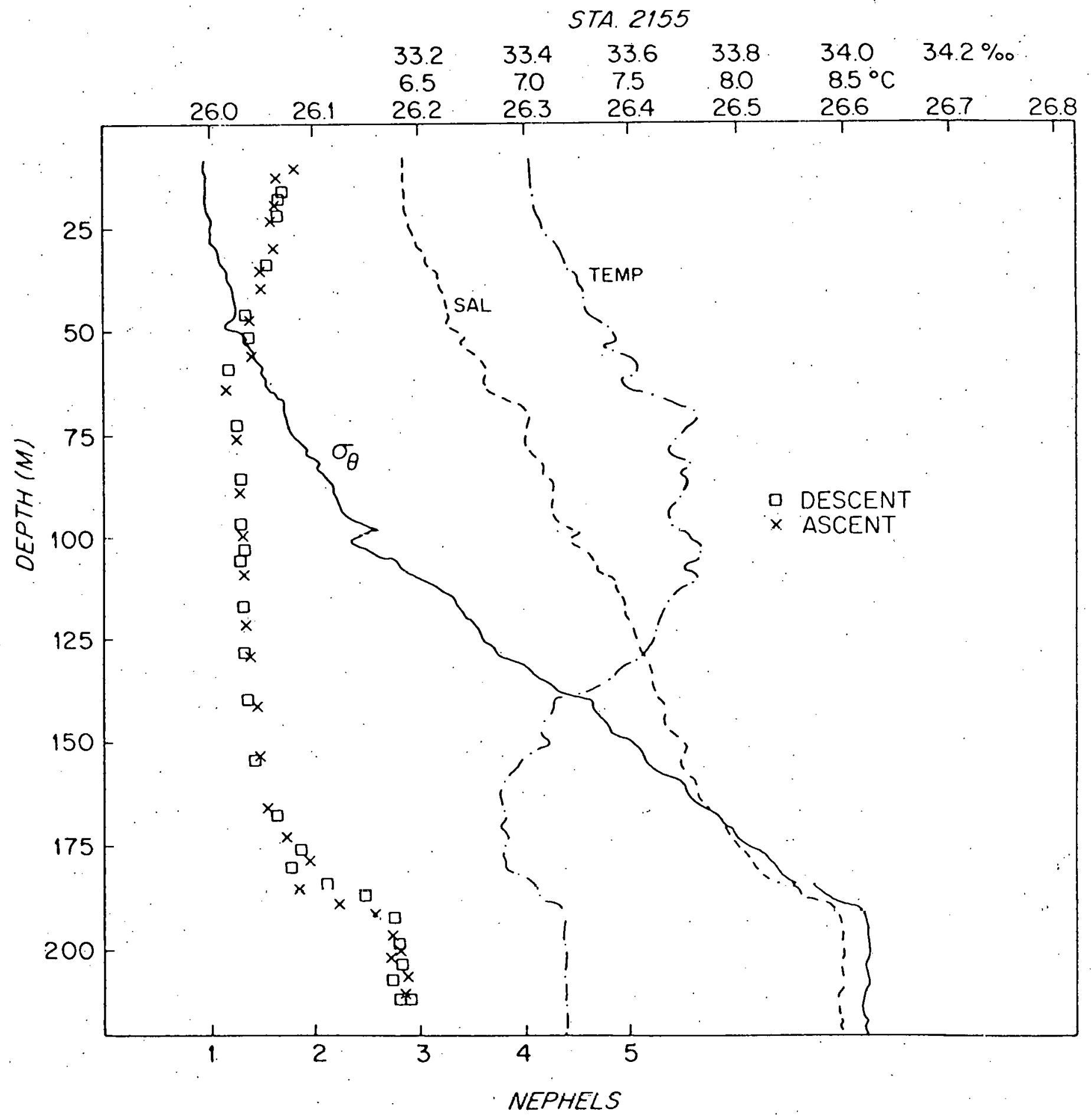

Fig. 19 
APPENDIX 1

Station locations and casts 
ATLANTIS I I CRUISE 86 LEG .1 (a)

GULF OF MAINE

\begin{tabular}{|c|c|c|c|c|c|c|c|c|c|}
\hline Station & Cast & Type & Date & Time & $\begin{array}{l}\stackrel{N}{ }{ }^{\frac{1}{i}} \\
\text { Deg. }\end{array}$ & $\begin{array}{l}\text { tude } \\
\text { Min. }\end{array}$ & $\begin{array}{l}\text { Lon } \\
\text { Deg }\end{array}$ & $\begin{array}{l}\frac{W}{i} \text { tude } \\
\text { Min. }\end{array}$ & $\begin{array}{c}\text { Depth } \\
\text { (m) }\end{array}$ \\
\hline \multirow[t]{9}{*}{2122} & 1 & CTD & $1 / 4 / 75$ & 2118 & 42 & 42.17 & 69 & 38.90 & 277 \\
\hline & 2 & NWEPHEL & & 2152 & 42 & 42.00 & 69 & 39.60 & \\
\hline & 3 & NISKIN & & 2245 & 42 & 41.32 & 69 & 39.96 & \\
\hline & 4 & BODMAN & $1 / 5 / 75$ & 0020 & 42 & 40.53 & 69 & 39.23 & $281 \cdot 1$ \\
\hline & 5 & NISKIN & & 0612 & 42 & 41.81 & 69 & 41.32 & 270 \\
\hline & 6 & BODMAN & & 0740 & 42 & 40.76 & 69 & 41.12 & \\
\hline & 7 & NISKIN & & 0818 & & & & & 267 \\
\hline & 8 & $\begin{array}{l}\text { PLANKTON } \\
\text { TOW }\end{array}$ & & 1538 to & +42 & 39.5 & 69 & 43.0 & \\
\hline & 9 & CTD & & 1647 & 42 & 41.0 & 69 & 43.0 & 255 \\
\hline \multirow[t]{2}{*}{2123} & 1 & CTD & $1 / 5 / 75$ & 2003 & 43 & 02.8 & 69 & 47.4 & 172 \\
\hline & 2 & NANSEN & & 2055 & 43 & 2.51 & 69 & 48.29 & \\
\hline \multirow[t]{4}{*}{2124} & 1 & CTD & & 2203 & 43 & 01.4 & 69 & 55.0 & 207 \\
\hline & 2 & CORE & & 2308 & 43 & 01.0 & 69 & 56.7 & \\
\hline & 3 & $\begin{array}{l}\text { PLANKTON } \\
\text { TOW }\end{array}$ & & 2346 to & $\rightarrow 43$ & 01.39 & 69 & 58.42. & 210 \\
\hline & 4 & NEPHEL & $1 / 6 / 75$ & 0005 & 43 & 01.94 & 70 & 01.79 & \\
\hline 2125 & 1 & CTD & $1 / 6 / 75$ & 0040 & 43 & 02.5 & 70 & 02 & 51 \\
\hline 2126 & 1. & CTD & $1 / 6 / 75$ & 0250 & 42 & 50.3 & 70 & 02.2 & 147 \\
\hline 2127 & $i$ & CTD & $1 / 6 / 75$ & 0438 & 42 & 51.54 & 69 & 56.34 & 205 \\
\hline \multirow[t]{4}{*}{2128} & 1 & NISKIN & & 0640 & & & & & \\
\hline & 2 & CTD & $1 / 6 / 75$ & 1021 & 42 & 52.0 & 69 & 48.9 & 254 \\
\hline & 3 & NEPHEL & & 1042 & 42 & 52.1 & 69 & 48.3 & \multirow[t]{2}{*}{1} \\
\hline & 4 & $\begin{array}{l}\text { PI ANKTON } \\
\text { TOW }\end{array}$ & & $1114 t . n$ & $4 ?$ & 52.3 & 69 & 47.1 & \\
\hline 2129 & 1 & CTD & $1 / 6 / 75$ & 1138 & 42 & 52.5 & 69 & 46.5 & 227 \\
\hline 2130 & 1 & CTD & $1 / 6 / 75$ & 1245 & 42 & 53 & 69 & 41.5 & 180 \\
\hline \multirow[t]{3}{*}{2131} & 1 & CTD & $1 / 6 / 75$ & 1442 & 42 & 46.0 & 69 & 31.0 & 181 \\
\hline & 2 & NEPHEL & & 1510 & 42 & 46.1 & 69 & 30.34 & \\
\hline & 3 & NANSEN & & 1535 & 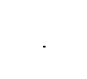 & & & & \\
\hline
\end{tabular}


Station Cast Type Date Time Latîtude Long $\stackrel{N}{\frac{N}{T}}$ (ude Depth

Deg. Min. Deg. Min.

(m)

\begin{tabular}{|c|c|c|c|c|c|c|c|c|c|}
\hline \multirow[t]{2}{*}{2132} & 1 & CTD & $1 / 6 / 75$ & 1710 & 42 & 45.5 & 69 & 36.5 & \multirow[t]{2}{*}{241} \\
\hline & 2 & NEPHEL & & 1738 & 42 & 44.67 & 69 & 37.09 & \\
\hline 2133 & 1 & CTD & $1 / 6 / 75$ & 1925 & 42 & 40.60 & 69 & 49.59 & 258 \\
\hline 2134 & 1 & CTD & $1 / 6 / 75$ & 2120 & 42 & 39.2 & 69 & 54.1 & 190 \\
\hline \multirow[t]{2}{*}{2135} & 1 & CTD & $1 / 7 / 75$ & 0000 & 42 & 20.6 & 70 & 00.6 & 181 \\
\hline & 2 & \multicolumn{2}{|l|}{$\begin{array}{l}\text { PLANKTON } \\
\text { TOW }\end{array}$} & 0118 to $\rightarrow$ & 42 & 22.5 & 69 & 56.3 & \\
\hline 2136 & 1 & CTD & $1 / 7 / 75$ & 0138 & 42 & 23.0 & 69 & 55.5 & 164 \\
\hline $2136 \mathrm{~A}$ & 2 & CORE & & 0245 & 42 & 21.9 & 69 & 55.1 & 211 \\
\hline 2137 & 1 & CTD & $1 / 7 / 75$ & 0528 & 42 & 28.7 & 69 & 37.8 & 256 \\
\hline 2138 & & arrive & $1 / 7 / 75$ & 0742 & 42 & 32.4 & 69 & 31.5 & 284 \\
\hline \multirow[t]{3}{*}{. } & & & & & \multicolumn{4}{|c|}{ heavy weather } & \\
\hline & & \multicolumn{2}{|c|}{$\begin{array}{r}\text { return to station } \\
1 / 7 / 75\end{array}$} & 1925 & 42 & 36.4 & 69 & 29.0 & 278 \\
\hline & & \multicolumn{2}{|c|}{ leave station } & 2220 & & & & & 266 \\
\hline 2139 & 1 & CTD & $1 / 8 / 75$ & 0020 & 42 & 35 & 69 & 21 & 225 \\
\hline 2140 & 1 & CTD & $1 / 8 / 75$ & 0255 & 42 & 39.3 & 69 & 10.9 & 175 \\
\hline \multirow[t]{2}{*}{2141} & 1 & CTD & $1 / 8 / 75$ & 0545 & 42 & 34.5 & 68 & 43.0 & \multirow[t]{2}{*}{195} \\
\hline & 2 & $\begin{array}{l}\text { PLANKTON } \\
\text { TOW }\end{array}$ & & 0620 & 42 & 32.5 & 68 & 43.5 & \\
\hline 2142 & $\mathrm{~T}$ & CTD & $1 / 8 / 75$ & 0738 & 42 & 30.5 & 68 & 51.7 & 210 \\
\hline 2143 & 1 & CTD & $1 / 8 / 75$ & 0903 & 42 & 27.3 & 68 & 58.5 & 224 \\
\hline \multirow[t]{3}{*}{2144} & 1 & CT.D & $1 / 8 / 75$ & 1210 & 42 & 22.0 & 69 & 16.0 & 240 \\
\hline & 2 & NISKIN & & 1300 & & & & & \multirow[t]{2}{*}{. } \\
\hline & 3 & $\begin{array}{l}\text { PLANKTON } \\
\text { TOW }\end{array}$ & & 1324 & 42 & 20.02 & 69 & 15.86 & \\
\hline 2145 & 1 & CTD & $1 / 8 / 75$ & 1415 & 42 & 19.0 & 69 & 26,4 & 221 \\
\hline \multirow[t]{2}{*}{2146} & 1 & CTD & $1 / 8 / 75$ & 1550 & 42 & 16.3 & 69 & 38.5 & \multirow[t]{2}{*}{242} \\
\hline & 2 & NANSEN & & 1658 & 42 & 15.8 & 69 & 38.3 & \\
\hline \multirow[t]{3}{*}{2147} & 1 & CTD & $1 / 8 / 75$ & 1835 & 42 & 12.1 & 69 & 52.5 & \multirow[t]{3}{*}{155} \\
\hline & 2 & NANSEN & & 1909 & & & & & \\
\hline & 3 & $\begin{array}{l}\text { PLANKTON } \\
\text { TOW. }\end{array}$ & & 1918 & & & & & \\
\hline 2148 & 1 & CTD & $1 / 8 / 7.5$ & 2147 & 42 & 06 & 69 & 28 & 178 \\
\hline \multirow[t]{3}{*}{2149} & 1 & CTD & $1 / 8 / 75$ & 2310 & 42 & 03.38 & 69 & 32.85 & \multirow[t]{3}{*}{216} \\
\hline & 2 & NISKEN & $1 / 9 / 75$ & 0005 & 42 & 03 & 69 & 34 & \\
\hline & 3 & $\begin{array}{l}\text { BOD. \& } \\
\text { NANSEN }\end{array}$ & & 0113 & & & & & \\
\hline
\end{tabular}




\begin{tabular}{|c|c|c|c|c|c|c|c|c|c|}
\hline \multirow{2}{*}{$\begin{array}{c}\text { Station } \\
2149\end{array}$} & \multirow{2}{*}{$\frac{\text { Cast }}{4}$} & \multirow{2}{*}{$\begin{array}{l}\text { Type } \\
\text { BOD \& \& } \\
\text { NANSEN }\end{array}$} & Date & Time & \multicolumn{2}{|c|}{$\begin{array}{l}\text { Latītude } \\
\text { Deg. Min. }\end{array}$} & \multicolumn{2}{|c|}{$\begin{array}{l}\text { Lon } \frac{W}{9} i \text { tude } \\
\text { Deg. Min. }\end{array}$} & $\begin{array}{c}\text { Depth } \\
(\mathrm{m})\end{array}$ \\
\hline & & & $\theta$ & 0129 & & & & & \\
\hline & 5 . & $" 1$ & & 0144 & & & & & \\
\hline & 6 & $"$ & & 0157 & & & & & \\
\hline & 7 & $\begin{array}{l}\text { PLANKTON } \\
\text { TOW }\end{array}$ & & 0235 & & & & & \\
\hline 2150 & 1. & CTD & $1 / 9 / 75$ & 0330 & 42 & 02.33 & 69 & 42.60 & 186 \\
\hline 2151 & $\cdot$ & CMC BODMAN & $1 / 9 / 75$ & 0630 & 42 & 26.47 & 69 & 44.60 & 272 \\
\hline 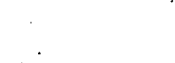 & & & & 0936 & 42 & 26.36 & 69 & 45.18 & 279 \\
\hline & & $\begin{array}{l}\text { PLANKTON } \\
\text { TOW }\end{array}$ & & 1310 & 42 & 25.69 & 69 & 46.16 & \\
\hline 2152 & 1 & CTD & $1 / 11 / 75$ & 0110 & 42 & 26.5 & 68 & 58.1 & 225 \\
\hline & 2 & NEPHEL & & & & & & & \\
\hline 2153 & 1 & CTD & $1 / 11 / 75$ & 0248 & 42 & 24.3 & 69 & 06.5 & $27 \cdot 8$ \\
\hline & 2 & NEPHEL & & & & & & & \\
\hline 2154 & 1 & CTD & $1 / 11 / 75$ & 0420 & 42 & 22.0 & 69 & 16.0 & 247 \\
\hline & 2 & NEPHEL & & & & & & & \\
\hline 2155 & 1 & CTD & $1 / 11 / 75$ & 0550 & 42 & 18.6 & 69 & 26.5 & 224 \\
\hline & 2 & NEPHEL & & & & & & . & \\
\hline 2156 & 1 & CTD & $1 / 11 / 75$ & 0733 & 42 & 16.5 & 69 & 40.0 & 242 \\
\hline & 2 & NEPHEL & & 0754 & & . & & & \\
\hline
\end{tabular}


APPENDIX 2

Summary of corrected CTD data 
ST. NOa 2123

DATE: $75 \cdots 15$

LOKo NOA 1 INSTO NO O

TIME CONST: = 3.0 .0

2

43.208 if.65 $47.4 \mathrm{k}$

\begin{tabular}{|c|c|c|c|c|c|}
\hline $\begin{array}{l}\text { PRESS } \\
\text { OE }\end{array}$ & $\begin{array}{l}\text { TEMP } \\
\text { OEG C }\end{array}$ & $\begin{array}{c}\text { SALINITY } \\
B / D D:\end{array}$ & $\begin{array}{c}\text { COND. } \\
\text { MMHO/CM }\end{array}$ & SIBMA-T & $\begin{array}{l}\text { PQT. } \\
\text { TEFP. }\end{array}$ \\
\hline & & & & & \\
\hline 166.0 & 6.8347 & 33.7463 & 34.1128 & 26.4640 & 6.8724 \\
\hline 16304 & $5.99=7$ & 33.6415 & $34 \cdot 1087$ & 26.3729 & 6.05719 \\
\hline 15306 & 7.1157 & $33: 5750$ & 3401527 & 2603325 & 7.1044 \\
\hline 147.2 & 7.3337 & 33.5368 & .34 .2654 & 26.02352 & 702729 \\
\hline 14905 & 7.4382 & 33.4457 & 34.3734 & $26 \cdot 1521$ & 7.4779 \\
\hline $1320 \overline{5}$ & 7.4757 & 33.4235 & 34.3354 & 2601330 & 7.4561 \\
\hline 126.8 & 7.4562 & 3504061 & 3403874 & 26.1219 & 7.4573 \\
\hline 120.1 & $7 \cdot 4552$ & .33 .4858 & $34 \cdot 3.54$ & 26.1209 & 7.4563 \\
\hline 11301 & 7.4747 & 33.4044 & 3403374 & 2601124 & $\pi_{0} 457 \pm$ \\
\hline $18: 6 \cdot 5$ & 7.4742 & 33.43 .36 & 34.3054 & 2601179 & 7.4672 \\
\hline 5906 & 7.4757 & 33.4033 & 34.314 & 26.1175 & 7.4653 \\
\hline $9: 206$ & 7.4617 & 33.4395 & 34.2634 & $26.117 j$ & 7.4560 \\
\hline 86.2 & 7.4517 & 33.3983 & $.34: 2694$ & 26.1169 & 7.4466 \\
\hline 7902 & 7.4547 & $33 \cdot 3975$ & 34.2684 & 26.1159 & 7.4503 \\
\hline 72.1 & 7.4237 & 33.3885 & 34.2294 & 2601132 & 704293 \\
\hline $65 \cdot 1$ & 7.2427 & 3303504 & 34.128 .5 & 26.1425 & 702396 \\
\hline 58.0 & 7.2587 & $33: 3274$ & 34.3215 & $26 \cdot 0353$ & 7.256 .3 \\
\hline 53.6 & 70.2287 & 33.3294 & 33.9926 & 260.548 & 7.2273 \\
\hline $43 \cdot 2$ & 7.02292 & 35,3311 & $5 \overline{5} .9916$ & 26.8953 & 7.2231 \\
\hline 36.8 & $7 \cdot 27 z 2$ & 35.3312 & 54.3275 & $26 \cdot 0.8 \div 3$ & j. .2 .723 \\
\hline 2500 & 7.2817 & 33.3158 & 54 o. 215 & 2602791 & 702819 \\
\hline $22 \cdot 5$ & 7.2137 & 33.3291 & 32.9666 & 26.0958 & 7.02146 \\
\hline 15.1 & 7.02157 & 33.3253 & $33 \cdot 9516$ & 26.2926 & $7 \cdot 217 ?$ \\
\hline 11.6 & 7.2217 & $33 \circ 3299$ & 33.9696 & 26.0954 & 7.2236 \\
\hline $7 \cdot 1$ & 7.02642 & 3303269 & 34.3 .325 & $25 \cdot 0871$ & 7.2665 \\
\hline
\end{tabular}


AII 7.96

ST NO. 2124

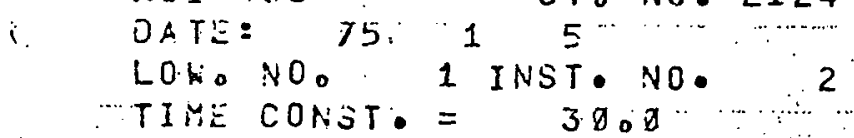
$431.4 N 695500$ क

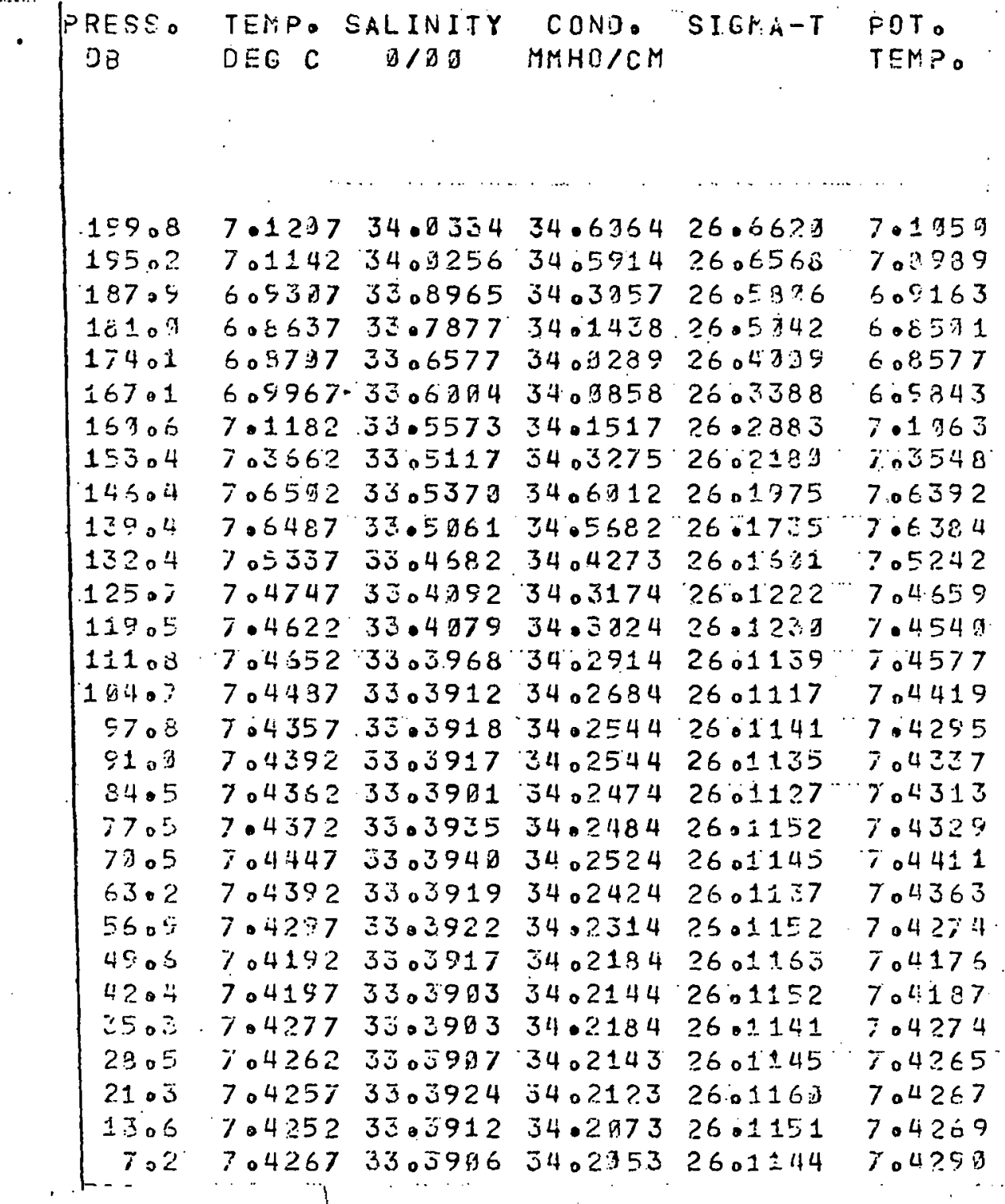


AII $\# 36$

ST. NE. 2125

JAंTS:

6

(. LGNONOO 1 INSTONOO . 2

TIME CONST: $=303$

432.5 iN $70.200 \mathrm{H}$

PRESS
DE TEMPO SALINITY CONDO SIGMA-T POT.
DEG C HIDO: MMHO/CM

43.27 .0249233 .325234 .00362600878

7.02482

$3900 \quad 7.247733 .3238 \quad 33.999626 .3870$

7.2470

$3500.702407 \quad 33032103309836 \quad 260.8357$

7. 02494

$39.2 \quad 7.0237233 .32013309326 \quad 2603355$

$25.3 \quad 7.2187 \quad 33.3333 \quad 33.9486 \quad 26.3749$

$29022^{\cdots \cdots} 7.1757-330286233.08926 " 2600674$

$13.7 \quad 701937 \quad 33028923309106 \quad 2602673$

$18.4 \therefore 7.176235 .2811 .33 .8876 .26 .3654$

$18.7 .70172733 .28113308846 \quad 2606638$

7.02374

7..2153

701768

7.1949

$19.7-7.17323302896,33.8946260 .0633$

7.1774

701739

$18.7 \quad 7.1757 .35 .2826 \quad 33.8886 \quad 26.0645$

7.1744

$15.8 \quad 70174733028273308866 \cdots 2600648$

7.1769

$11.77 .1822 .3302829 .33 .8916 \quad 26.2639$

7.1762

$9.9 \cdots 7.2332 \cdots 33.2341 \% 33.9366-26.0578$

7.1340

7.22353 


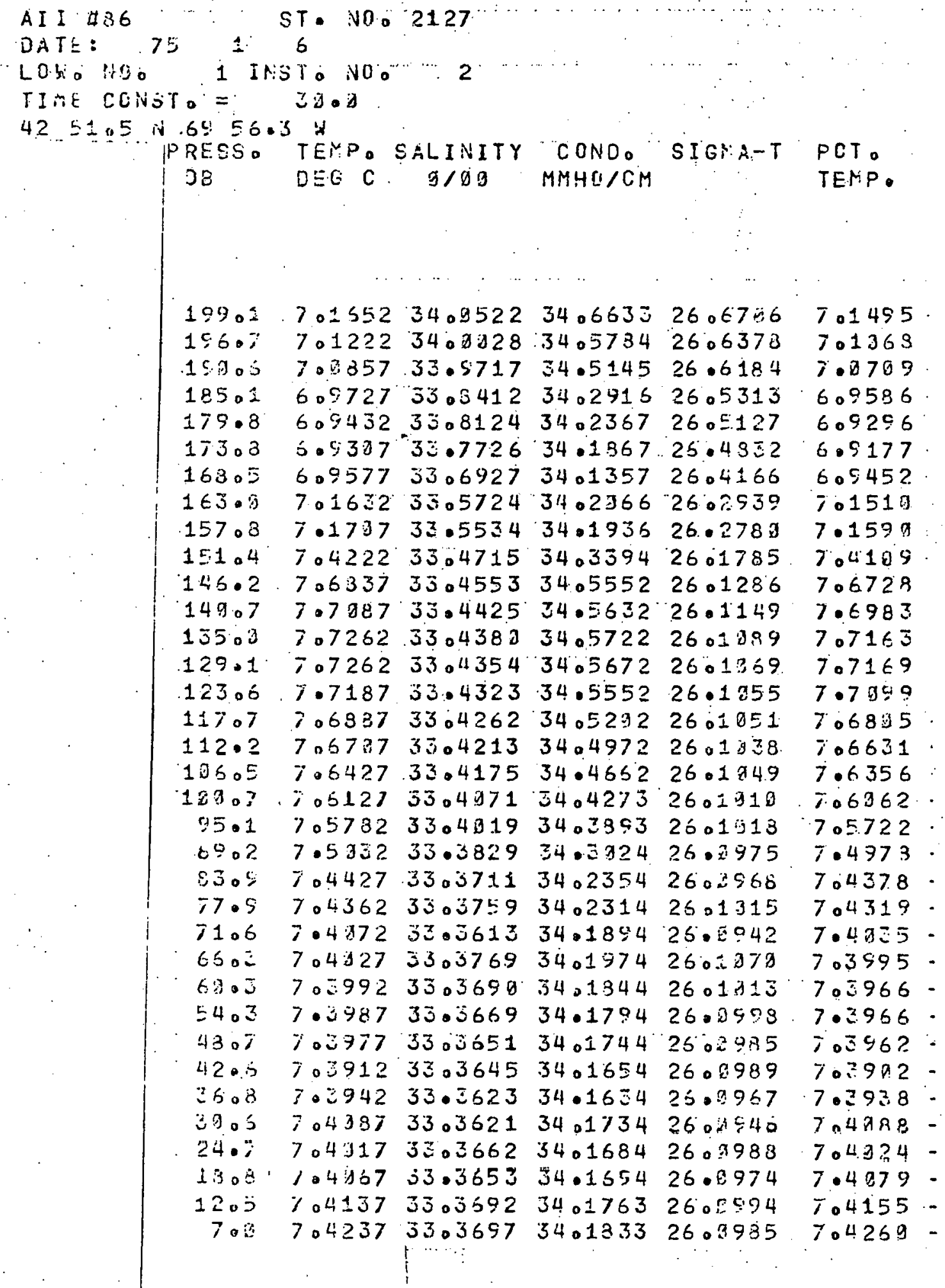




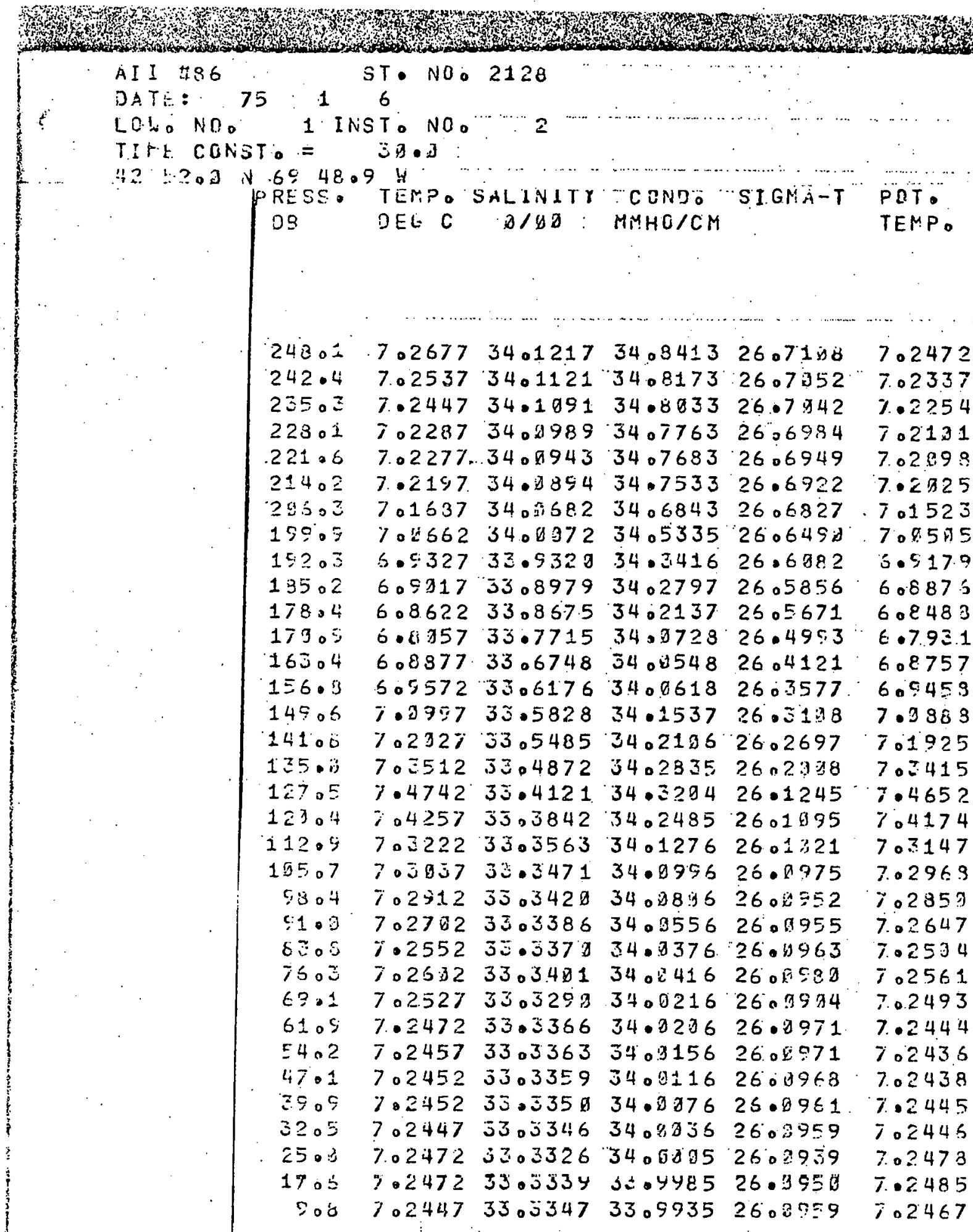


AII $\$ 86$

OATE:

\%

ST. NO. 2126

LOH. NOO 1

6

TIME CONST: =

1 INST。 NO.

$42 \mathrm{HJ} .3$ iN 70 . $2.2 \mathrm{H}$

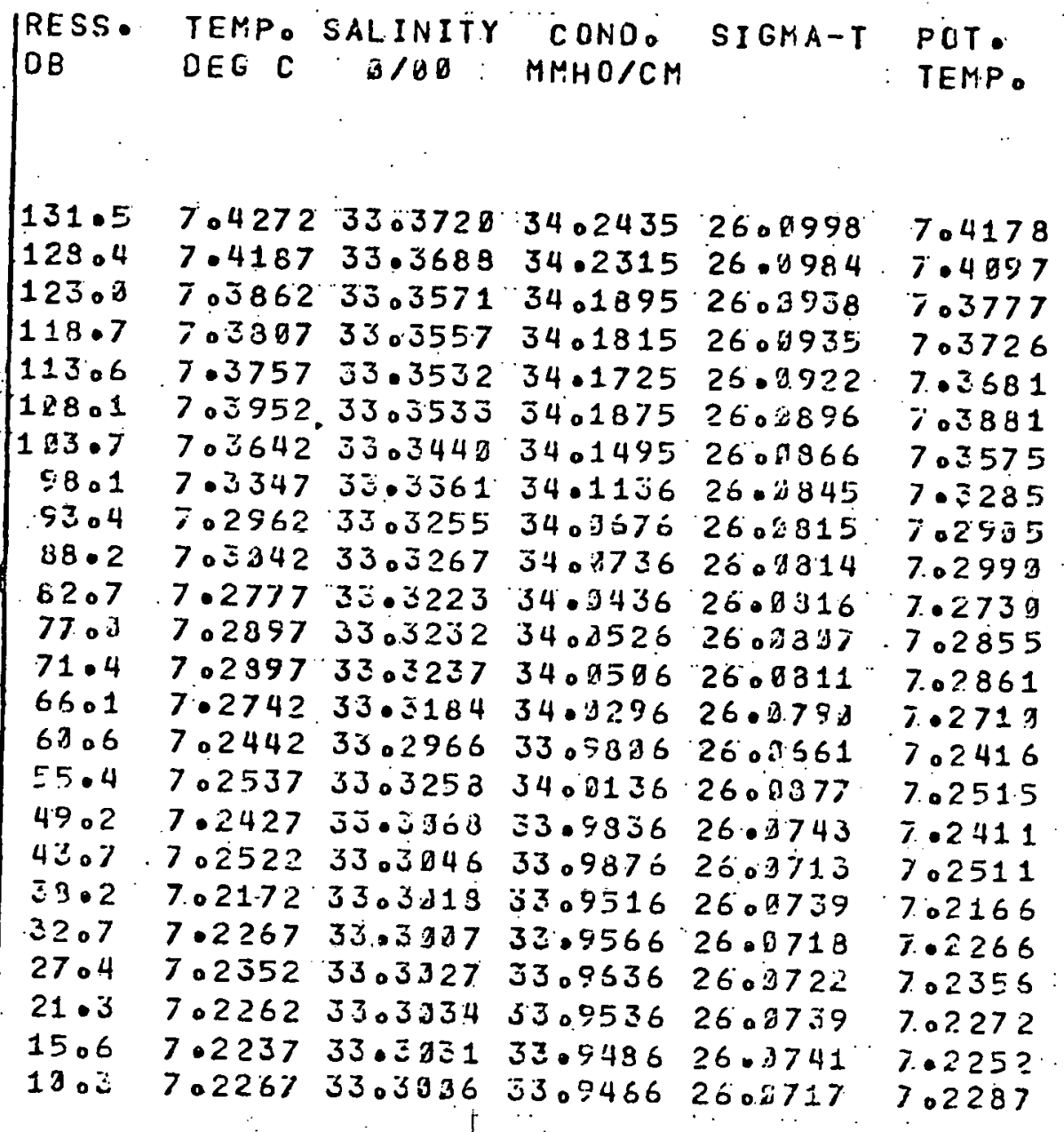


AI I $\pi 2.6$

DATI: :

LOS. S. NO O

TINE CONST:

STS NO. N 2129

4252.5 V $65: 46.5 \times 1 . \cdots$

PRESSO TEMP SALINITY CONDO SIEMA-T POTO
J3 DEG C OIDD MMHOICM

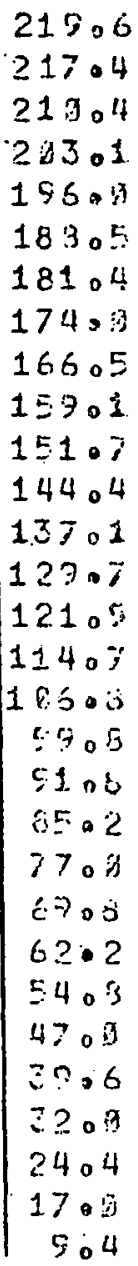

7.17173400642

7.16323400584

$34.6894 \quad 26 \cdot 6792$

7.1543

7.128234 .340634062442606666

$70 \pm 459$

$7.1282 \quad 34.8406 \quad 34.6244 \quad 26.6666$

7.1115

$70053734007583405335 \quad 2606521$

$7.0272 \quad 330996134.4965 \quad 2606456$

70.428

s.5352.33.:699 $34.42166^{\circ} 26.6398$

7.9123

$6.946733 .9378: 3403546 \quad 2606198$

6.51573308917340281726 .5788

$6.6667 .35 .8278 \quad 34.1757 \quad 26.5347$

$6.388733 .7386 \quad 3401118 \quad 26.4621$

$60969733063363401227 \quad 26.04091$

7.075733 .594534 .140726 .3233

$702732 \quad 33.5076 \quad 34.2515 \quad 26.2249$

$7.4352 \quad 3304465 \quad 340.3574 \quad 2601453$

$7.457233 .3965 \quad 34.2884 \quad 26.1147$

$7.3147: 3.3573$

34.1226

26011399

7.0250733034343402496

7.2246233 .341234 .9426

26.1 is 19

7.2327

33.3363

34.3206

26.1909

7.0231 .2

33.3377

34.9176

26.39 .89

7.2317

33.3378

3400146

26.1 .192

6.9787

605323

605326

6.8544

608771

505497

7.0653

7.2834

7.4769

7.4487

70379

7.02439

7.2399

$7.227 ?$

7.02 .253

7.2327330338134001262601003

7.. 2275

70233

33.3391

34.0196

2601843

$.7 .229 ?$

$7.2312 \cdot 33.5381$

34.3946

26.15 .13

7.02394

70238233.33743309906

$26 \cdot 1 \$ 35$

7.2251

7.02288

$7.0237733 .3492 \quad 3400256 \quad 2601012$

$7.2457 .33 .3394 \quad 34.9386 \quad 26.9995$

7.2373

7.2457

$7.249233 .3427 \quad 3403395 \quad 2601$ id

$7.240 \%$

7.253233 .3400

3408135

26.7982

7.02.596

$7.265233 .3423 \quad 34.0185 \quad 26.9951$

7.2673 
AII 496

DATE:

ST. NC. 2132

75i 16

LDHO NCO

1 INST NO.

2

TINE CONST: = $3 \mathrm{~J}_{0}$

425300 N $6541.5 . H$

\begin{tabular}{|c|c|c|c|c|c|}
\hline$D B$ & $\begin{array}{l}\text { TEMP } \\
\text { DEG C }\end{array}$ & $\begin{array}{c}\text { SALINITY } \\
B / B O\end{array}$ & $\begin{array}{l}\text { CEND. } \\
M M H O / C M\end{array}$ & SI GMA-T & $\begin{array}{l}\text { POT. } \\
\text { TEMP. }\end{array}$ \\
\hline & & & & & \\
\hline $\begin{array}{l}167 \cdot 5 \\
162.8 \\
157.5\end{array}$ & $\begin{array}{l}609392 \\
6.9387 \\
6.9367\end{array}$ & $\begin{array}{l}33.8222 \\
33.7 .327 \\
33.7258\end{array}$ & $\begin{array}{l}34.2367 \\
34.1527 \\
34.1397\end{array}$ & $\begin{array}{l}26.5219 \\
26.4507 \\
26.4433\end{array}$ & $\begin{array}{l}6.9267 \\
6.5267\end{array}$ \\
\hline $151 \cdot 1$ & 6.9897 & 33.5435 & 34.1117 & $26.37 \geq 6$ & 6.9788 \\
\hline $\begin{array}{l}145.7 \\
143.7\end{array}$ & $\begin{array}{l}6.9962 \\
7.9142\end{array}$ & $\begin{array}{r}33.6003 \\
33.5843\end{array}$ & $\begin{array}{l}3.4 .0757 \\
34.00747\end{array}$ & $\begin{array}{l}26.2387 \\
26.3235\end{array}$ & $\begin{array}{l}6.5858 \\
\% \circ B 842\end{array}$ \\
\hline $\begin{array}{l}135.4 \\
129.8 \\
124.5\end{array}$ & $\begin{array}{l}7.1597 \\
7.2227 \\
7.3477\end{array}$ & $\begin{array}{l}33.5596 \\
33.5174 \\
33.5064\end{array}$ & $\begin{array}{l}34.1796 \\
34.1946 \\
34.2935\end{array}$ & $\begin{array}{l}26.02343 \\
26.24 .5 \\
26.2164\end{array}$ & $\begin{array}{l}7.01591 \\
7.2136 \\
7.03397\end{array}$ \\
\hline 119,0 & 7.3712 & 33.3995 & $34.21 \geq 5$ & 26.12 & 7.03631 \\
\hline $\begin{array}{l}112.5 \\
106.3\end{array}$ & $\begin{array}{l}7.2 .922 \\
7.23 \geqslant 2\end{array}$ & $\begin{array}{l}32.3470 \\
33.3456\end{array}$ & $\begin{array}{l}54.9836 \\
34.3775\end{array}$ & $\begin{array}{l}26.1964 \\
26.9996\end{array}$ & $\begin{array}{l}7.02747 \\
7.2733\end{array}$ \\
\hline 59.6 & 7.02737 & $33: 3431$ & 34.0 .666 & 26.5985 & 7.02674 \\
\hline $\begin{array}{l}520.8 \\
86.2\end{array}$ & $\begin{array}{l}7.2717 \\
7.2562\end{array}$ & $\begin{array}{l}3 \Xi .3439 \\
3 \Xi .3416\end{array}$ & $\begin{array}{r}34.0626 \\
34.9526\end{array}$ & $\begin{array}{l}26.0955 \\
26.7984\end{array}$ & $\begin{array}{l}7.2661 \\
7.2612\end{array}$ \\
\hline 79.3 & 7.02637 & 33.3488 & 34.8466 & $26 \cdot 981$ & 7.02593 \\
\hline $\begin{array}{l}72.4 \\
65.2\end{array}$ & $\begin{array}{l}7.2627 \\
7.2617\end{array}$ & $\begin{array}{l}33.3417 \\
33.3496\end{array}$ & $\begin{array}{l}34.00436 \\
34.06386\end{array}$ & $\begin{array}{l}26.5989 \\
26.5983\end{array}$ & $\begin{array}{l}7.2590 \\
7.02586\end{array}$ \\
\hline $\begin{array}{l}5.3 .7 \\
51.6\end{array}$ & $\begin{array}{l}7.02577 \\
7.2542\end{array}$ & $\begin{array}{l}33.3389 \\
33.3381\end{array}$ & $\begin{array}{l}34.0376 \\
34.223 .6\end{array}$ & $\begin{array}{l}26.00975 \\
26.0973\end{array}$ & $\begin{array}{l}7.02552 \\
7.22524\end{array}$ \\
\hline $44 . t$ & $7 . \widehat{2522}$ & 33.3378 & 34.2185 & 2600974 & 7.2513 \\
\hline 37 & 7.2587 & $3 \overline{3}$ & 3403146 & 26.0 .4587 & 7.02502 \\
\hline & 157 & 32.5463 & 34.0086 & 26.1930 & $7 \cdot 2.453$ \\
\hline & +42 & 33.3359 & 340335 & $260 \%$ & 7.2449 \\
\hline $\begin{array}{l}17 \cdot 3 \\
19 \cdot 3\end{array}$ & $\begin{array}{l}7.02432 \\
7.2527\end{array}$ & $\begin{array}{l}3303369 \\
3 \equiv .3419\end{array}$ & $\begin{array}{l}33.5975 \\
34.7155\end{array}$ & $\begin{array}{l}26.5978 \\
26.9924\end{array}$ & $\begin{array}{l}7.02445 \\
7.2547\end{array}$ \\
\hline
\end{tabular}


AI I $3 B 6$ DATE:

$i$ STo"No: 2131

LOh. NO. 1 INST. NO

TIME CONST. = 30.3

42. 4508 is $69.31 .3 \mathrm{~W}$

\begin{tabular}{|c|c|c|c|c|}
\hline $\begin{array}{l}\text { RESS. } \\
\text { DB }\end{array}$ & $\begin{array}{l}\text { TEPIP } \\
\text { DEG C }\end{array}$ & $\begin{array}{c}\text { SALINITY } \\
\qquad / 93\end{array}$ & $\begin{array}{l}\text { CENDO } \\
M M H C / C M\end{array}$ & $S I G M A-T$ \\
\hline
\end{tabular}

\begin{tabular}{|c|c|c|c|c|c|}
\hline 03 & $7 \cdot 3357$ & 273 & 3405433 & 26.4630 & 702725 \\
\hline & 7.5682 & 257 & 34.7112 & .3573 & $55 \mathrm{z}$ \\
\hline$\cdot 4$ & 7.6272 & 3306965 & 34.7341 & $260 \geq \geq 59$ & 7.6153 \\
\hline $\begin{array}{l}15205 \\
14601\end{array}$ & $\begin{array}{l}707312 \\
70819.7\end{array}$ & $\begin{array}{l}33.6487 \\
33.5632\end{array}$ & $\begin{array}{l}34.7800 \\
34.7770\end{array}$ & $\begin{array}{l}26.2734 \\
26.435\end{array}$ & 7.7196 \\
\hline 909 & $7.8342^{\circ}$ & 33.5259 & 3408910 & $\begin{array}{l}260.930 \\
26: 1589\end{array}$ & 7 \\
\hline 3.3 & 7.6322 & 33.5123 & 34.780 & 26.2446 & 7.5724 \\
\hline 126.7 & 7.8767 & 3304993 & 34.7690 & 26.1351 & 7.08575 \\
\hline $123 \cdot 5$ & 7.8727 & 33.4985 & 34.7533 & 26.1351 & 7.8641 \\
\hline $1130 \%$ & 7.8317 & 33.4938 & 34.7358 & 26.1374 & $7 \cdot \varepsilon: 2 z$ \\
\hline 127.4 & 7.8552 & 33.4914 & 34.07250 & 2601321 & 70.949 \\
\hline $101 \cdot 2$ & 7.8462 & 33.4784 & 34.7920 & $26 \circ 1.232$ & 7.839 .5 \\
\hline 55.1 & 7.7792 & .33 .4672 & 6251 & $26 \cdot 1242$ & $7 \cdot 773$ \\
\hline 83.2 & 7.7632 & 33.4622 & 34.6071 & 26.1225 & 7.7578 \\
\hline $81 \cdot 8$ & 7.07497 & 33.4610 & 34.5911 & $26 \circ 12=5$ & 7.07453 \\
\hline 75.7 & $7 \cdot 7422$ & 32.4571 & $34: 5.781$ & $26 \cdot 1216$ & 7.738 \\
\hline 6902 & $7.73: 2$ & 33.4545 & 34.5621 & $26.1 ? 23$ & 707267 \\
\hline 62.6 & 7.7287 & $3 \approx .4537$ & $34.55 \% 1$ & $26 \circ 12: 3$ & $7.72 \equiv 3$ \\
\hline $56 \circ \pi$ & 7.7277 & $3 \Xi .45 \geq 4$ & 34.5531 & 26.5293 & 7.725 \\
\hline 49.7 & 7.7312 & 3304331 & 34.5530 & 2601283 & $707 ? 96$ \\
\hline $43 \cdot 2$ & 7.7292 & 33.4455 & 34.5450 & 26.1175 & $7072 \varepsilon 2$ \\
\hline 3606 & 7.7277 & $33.453 x$ & 34.5440 & 26.1285 & .7 .727 .5 \\
\hline 30.1 & 7.7217 & 33.4510 & 34.5340 & $2601 \div 95$ & 7.07215 \\
\hline $23 \cdot 6$ & 7.7217 & 3504509 & 3405310 & 2601197 & $: 07225$ \\
\hline 17.2 & 7.7152 & 33.4499 & 34.5250 & 26.1153 & $i 0.237$ \\
\hline 10.4 & 707122 & $33.448 g$ & 34.5148 & 2601196 & 707143 \\
\hline
\end{tabular}




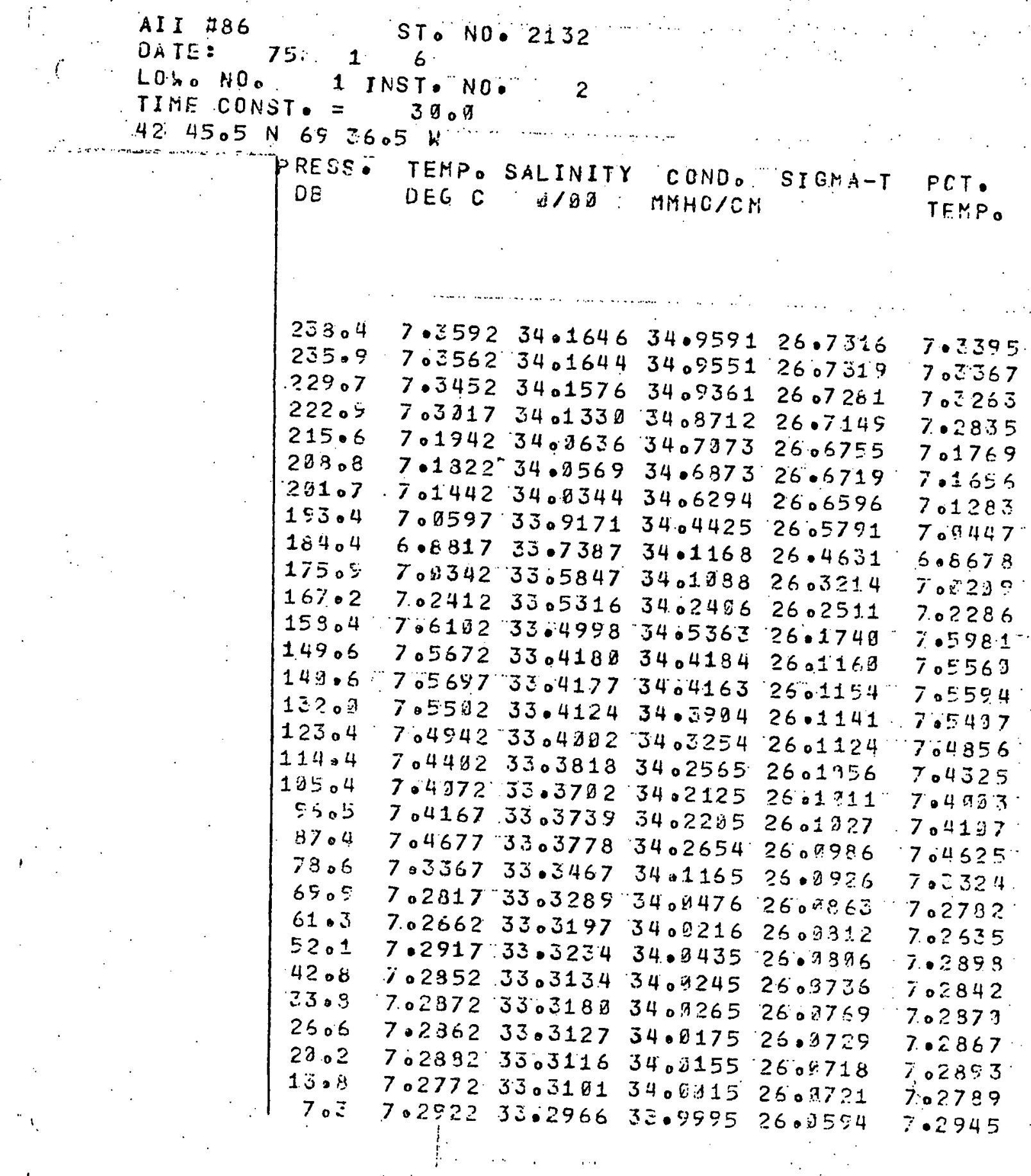




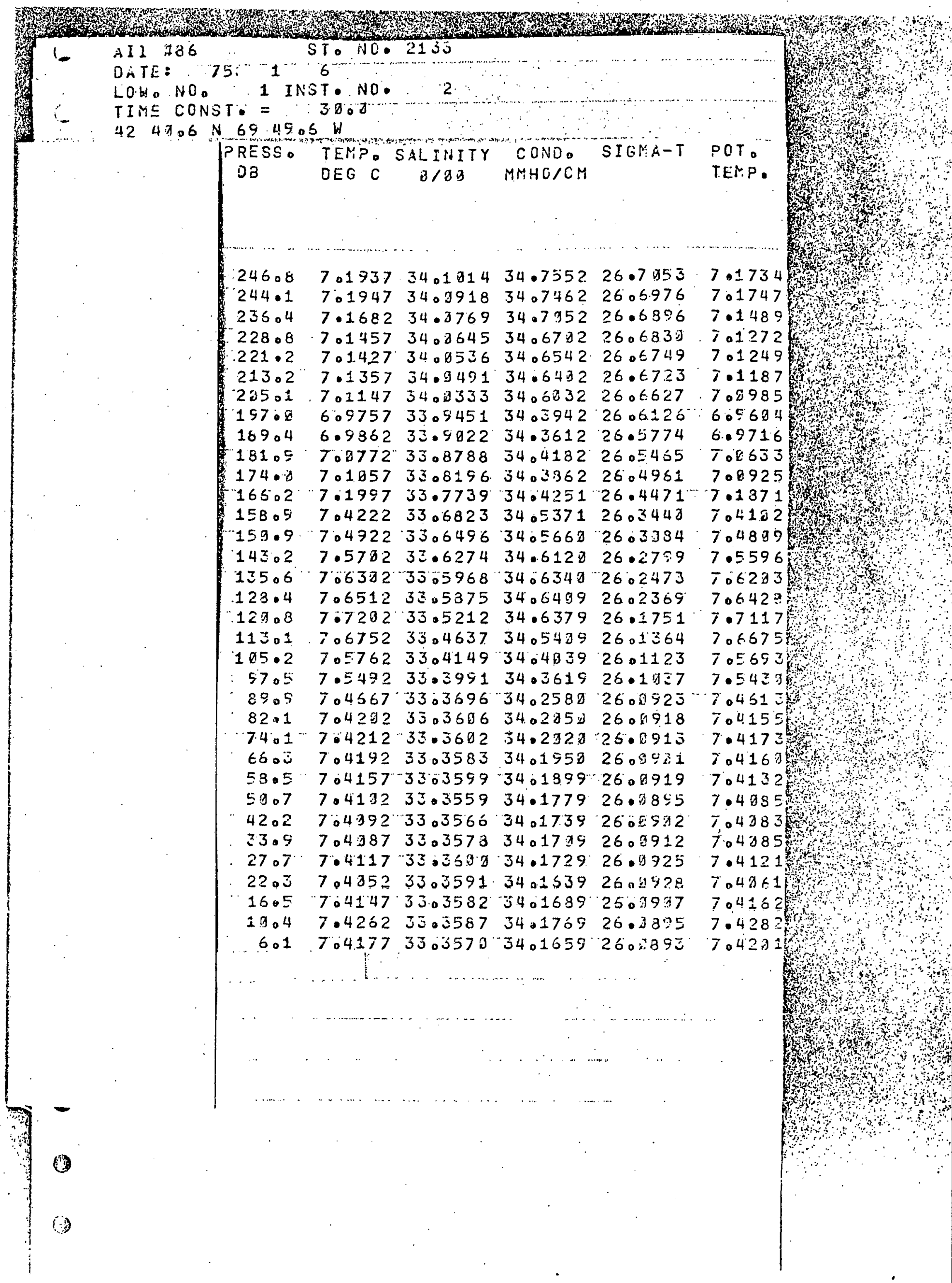




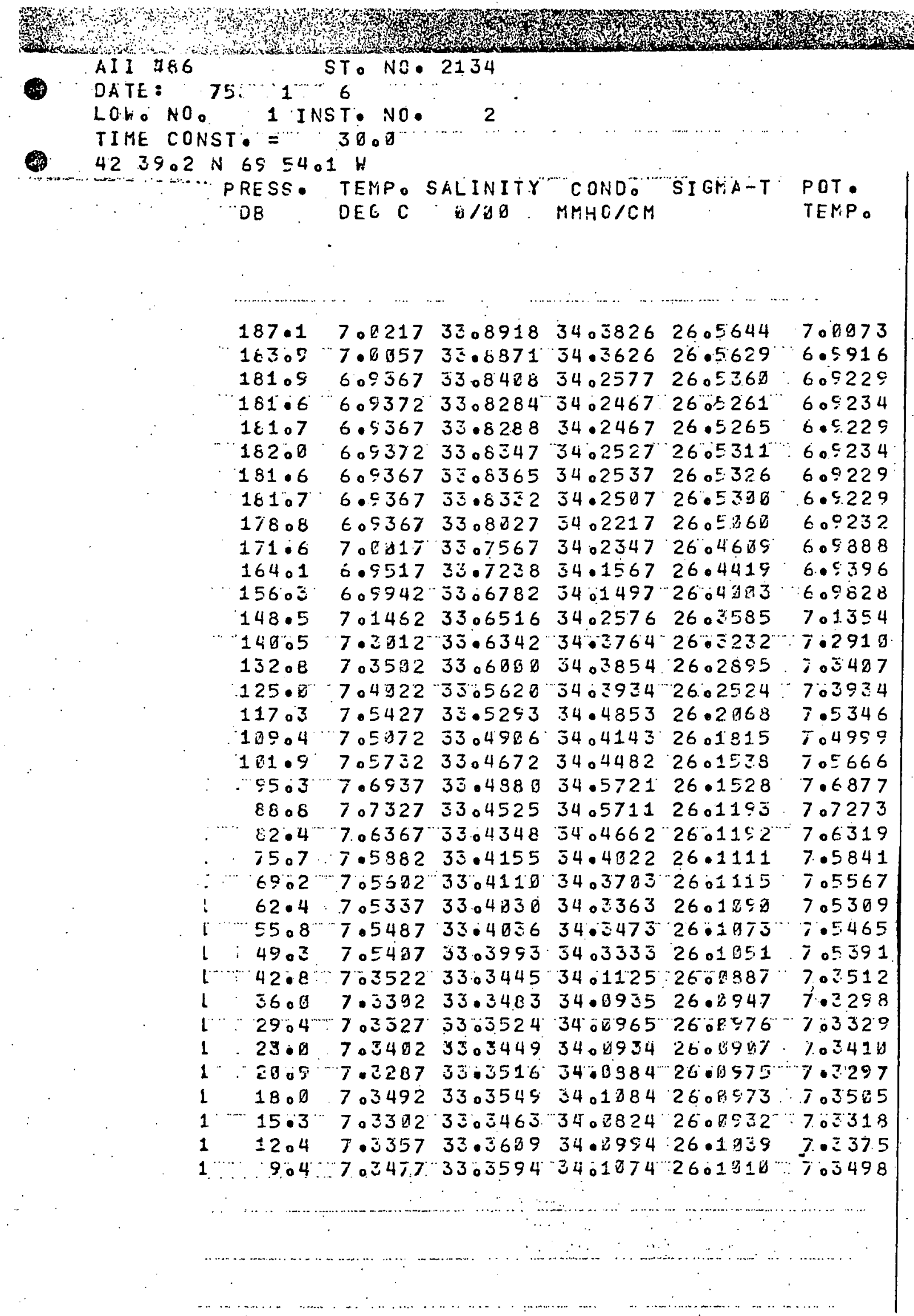









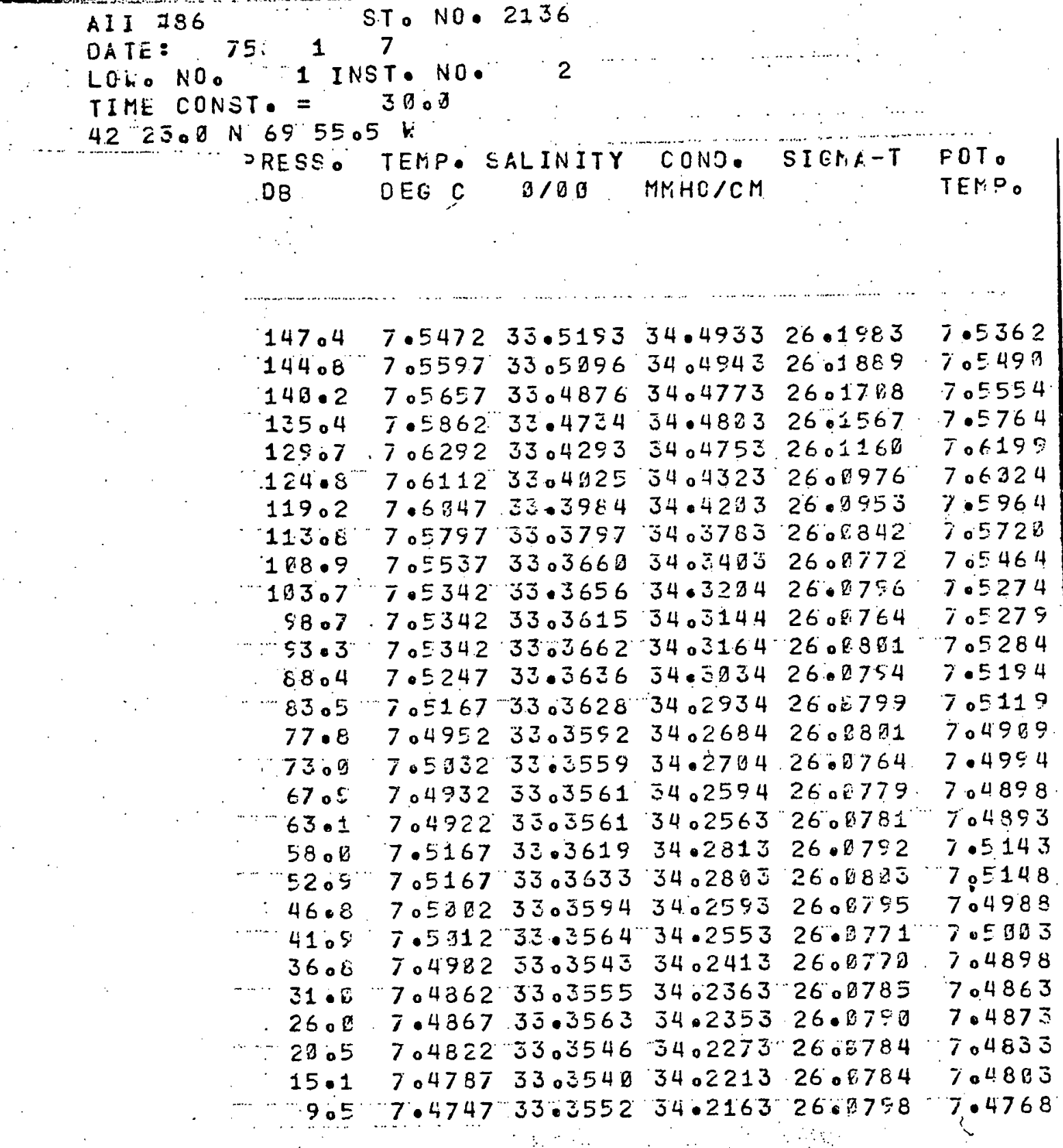




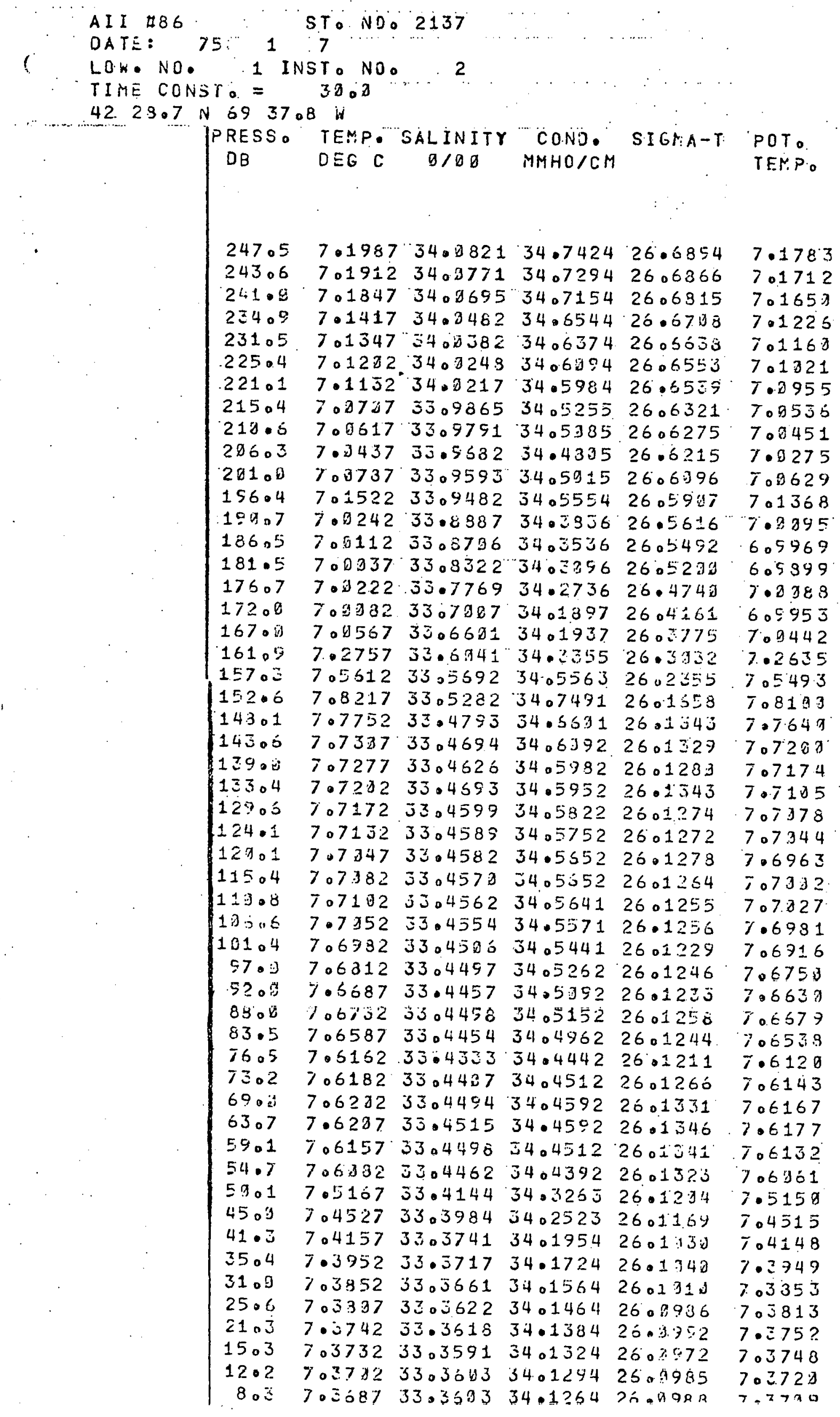




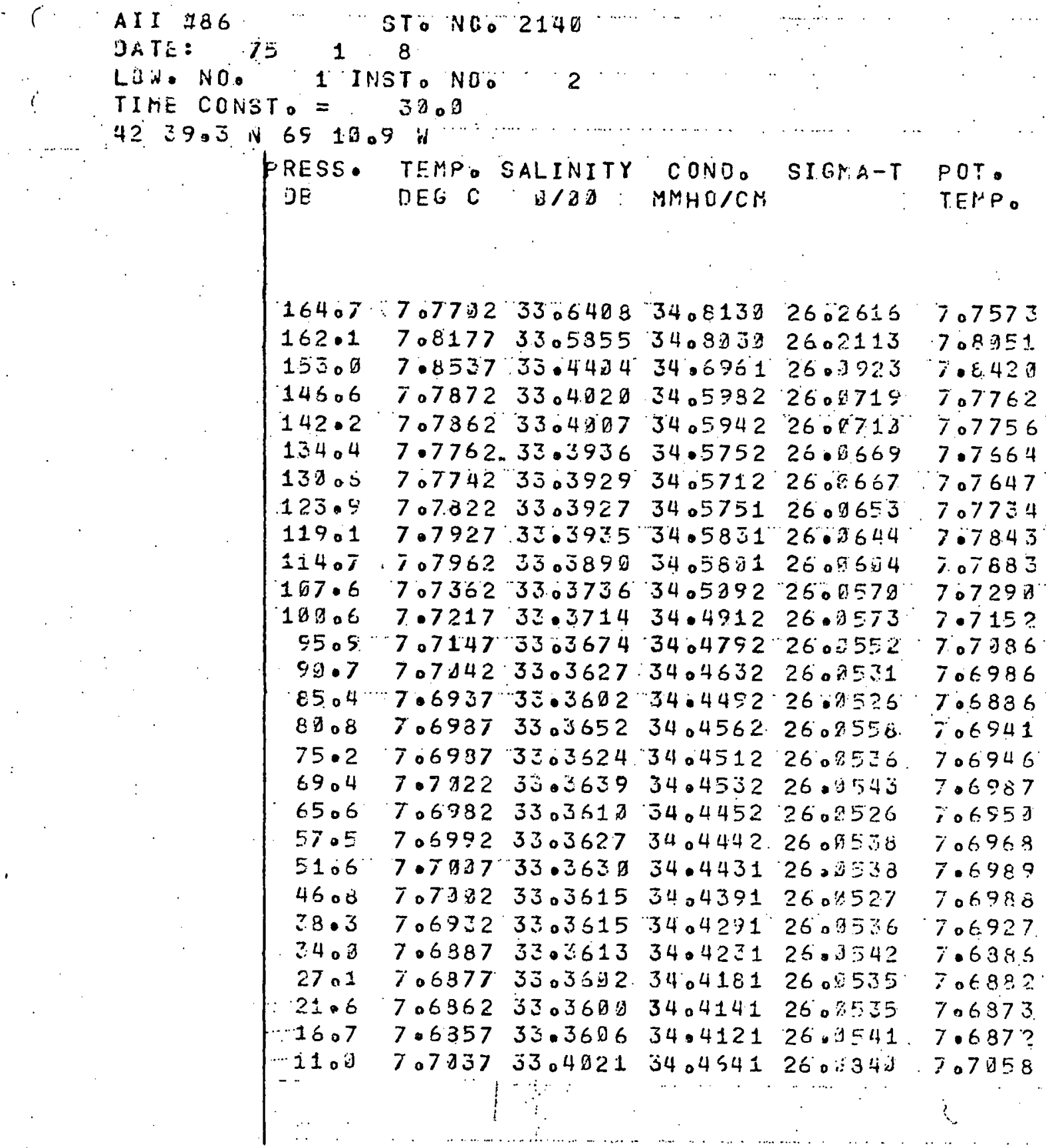




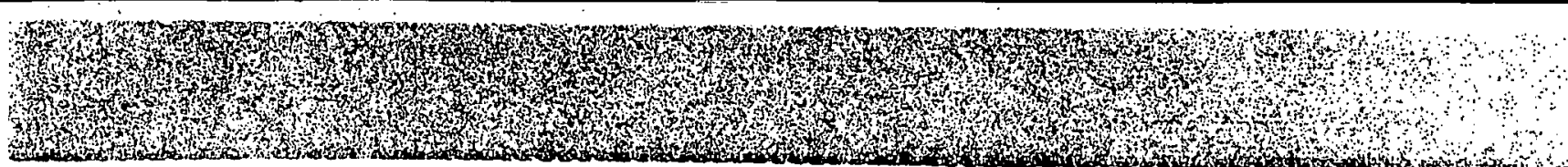

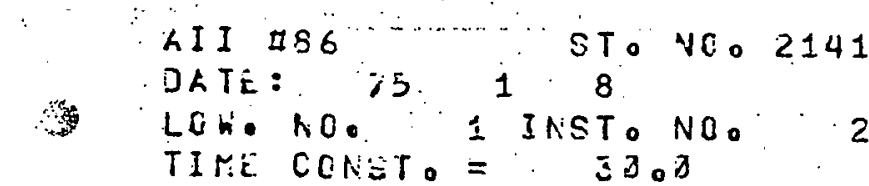

.4234 .5 i $6 \varepsilon^{\prime \prime} 4300 \mathrm{H}$

PRESS
DE TERP SALINITY CONDO SIERE-T PCTO

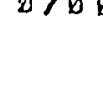

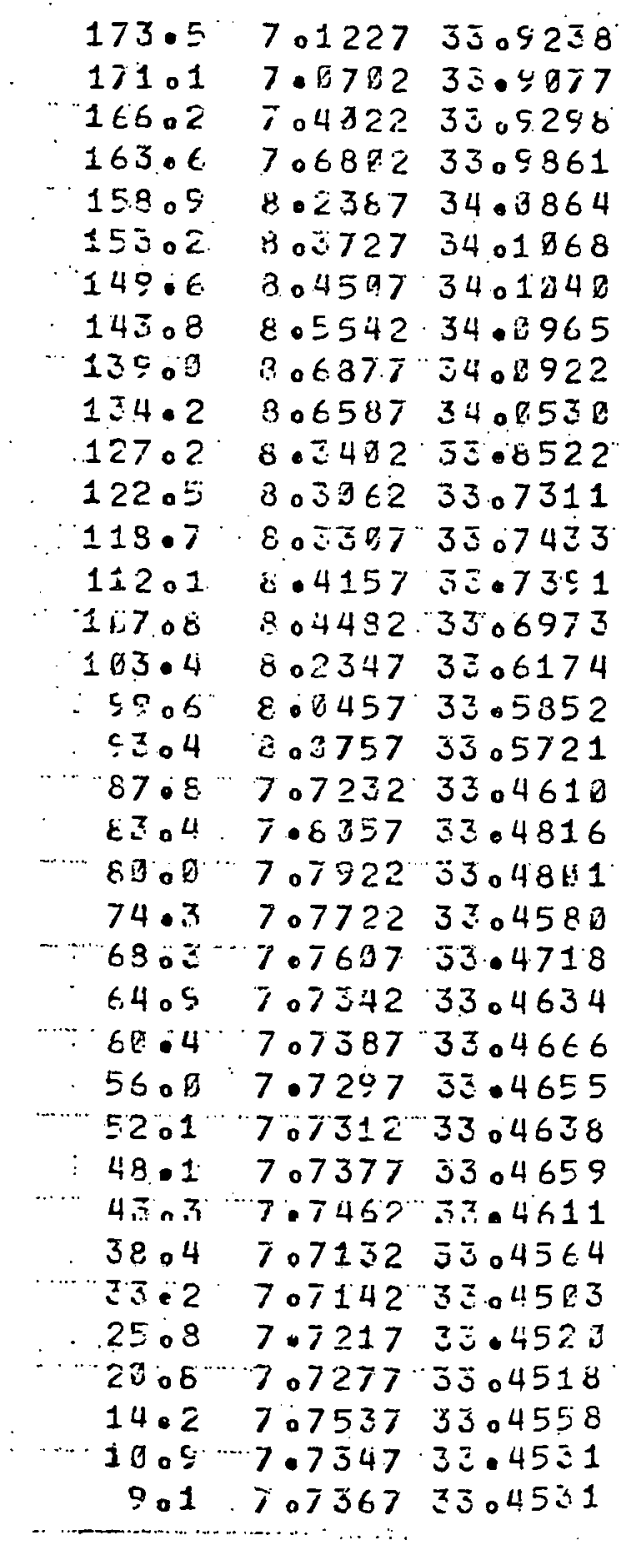

34.49642605756 $34.4335 \quad 26.5732$ 3407502.2605411 35075192605454 35.650326 .5413 25078912605.37 35085602605228 $35 \cdot 54099.26 \cdot 5110$ 36025602604760 3509909.2604507 55.650326 .512 .6 35035142602529 $3 \cdots 3503954 \quad 2602583$ $35.4633 \quad 26 \cdot 2: 4: 5$ 30.45132602346 $3501815 \quad 2601747$ $34.575726: 17 ; 6$ $340 \div 917260: 525$ 34057912603274 $34.661026 .1: 16$ $3406460260=324$ 34009502601179 $34.6852 \quad 26.1325$ 340572126.01277 340577220.1255 $34.5568 \quad 26 \cdot 1333$ $3405548 \quad 2601: 24$ $3405732 \quad 2601291$ $34.5712 \quad 26 \cdot: ? 41$ $3405552 \quad 260 \pm 252$ $3405232 \quad 260: 2 \pi 3$ $34 \cdot 52322602 ?: 0$ 340556826.1150 $3405512 \quad 260: 190$ $340 \leq 5 \leq 2 \quad 26 \cdot 1: 95$ $340542^{2} 260=1.2$

701395 7.0573 $70 \Xi 894$ 706674 $\varepsilon \cdot 2250$ 803644 द. 0.487 8.5429 $8.067 \in 7$ 0.0648 ? $\varepsilon .2536$ $E 0.2972$ $\varepsilon_{0} \overline{3} 220$ 8.4677 $\bar{c} .04406$ 8.07277 $\varepsilon .2551$ ६. ค. 6:? 707170 7.6398 7.07875 7.07682 $7.757 ?$ 7.07311 7.7369 7.7275 7.07293

707362

7.7452

707126

707141

7.7224

7.07286

707555

7.7368 7.07559 
AII 1186 JATE:

LaA. NO.

TIME CONGTO
STONBO 2142

8

1 INST O NOO 3903

$4233.5 N 605107$ i.

\begin{tabular}{|c|c|c|c|c|c|}
\hline DB. & $\begin{array}{l}T E H P \text { O } \\
D E E \quad C\end{array}$ & 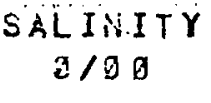 & $\begin{array}{l}\text { COND. } \\
\text { MMHE/CN }\end{array}$ & SI GP: $\wedge-T$ & TERPA \\
\hline $\begin{array}{l}15303 \\
18903\end{array}$ & $\begin{array}{l}7.8492 \\
7.8432\end{array}$ & $\begin{array}{l}34.2320 \\
34.2327\end{array}$ & $\begin{array}{l}35.4466 \\
35.4445\end{array}$ & $\begin{array}{l}26.7135 \\
26.7145\end{array}$ & $\begin{array}{l}7.83 \geq 3 \\
708327\end{array}$ \\
\hline 183.6 & 7.3457 & 34.1938 & 35.4336 & 2606842 & 7.8397 \\
\hline $17 \% 0$ & 7.8492 & 3401698 & 35.3826 & 25.5649 & $7 \cdot \varepsilon 347$ \\
\hline 173.0 & 387 & 34.1444 & 3503466 & 26 & 248 \\
\hline 166.5 & 582 & 3401174 & 35.3456 & & $54 ?$ \\
\hline 161 & 917 & 34.2759 & 35.3256 & & 7.8793 \\
\hline & 7.8597 & 3408379 & 35.2587 & 26.5 & 7.8464 \\
\hline 151 & 7.8312 & 3400 & 35.1317 & & $8 \div 5$ \\
\hline 14 & $7 \cdot 8232$ & 33.5723 & 35.1617 & 26 & \pm 9 \\
\hline $142 \pi \%$ & 7.8272 & 33.9668 & 35.1577 & 26 & 164 \\
\hline 4 & 708657 & 33 & 747 & & 55 \\
\hline 1 & 7.0242 & 33 & 30.7 & 26 & 45 \\
\hline 12 & $\%$ & 33 & 29 & 26 & 41 \\
\hline 12 & 703302 & 350 & 34.5403 & 26 & 217 \\
\hline 11 & 7.3257 & 32.7 & 34.4773 & 26 & 177 \\
\hline 11 & 706742 & 33.7 & 34.8190 & 26 & $655:$ \\
\hline 106 & 709472 & 330 & 35.9797 & & 7 \\
\hline $19 ?$ & a. & 33 & 35.4283 & & 927 \\
\hline 9700 & 0.5372 & 33 & 35.5571 & & 325 \\
\hline & 257 & $3 z$ & 373 & & 97 \\
\hline & 0.3212 & 33 & 314 & & 156 \\
\hline 8405 & 347 & 33 & 533 & & 48 \\
\hline $8: 3 \cdot 1$ & 704742 & 330 & 453 & & 1697 \\
\hline & 70 & 320 & 363 & & $4 ?$ \\
\hline & 704667 & 30 & 333 & & 31 \\
\hline $66 \cdot ?$ & 7.4677 & 3304 & 34.3323 & & 845 \\
\hline & 7.4547 & $3 z \cdot 4$ & 283 & & 629 \\
\hline$=6.5$ & 7.4072 & 33.4513 & 34.3233 & 26 & $7,0454 \%$ \\
\hline$=2 \cdot 4$ & 7.4692 & 3304652 & 34.3273 & 25 & 704673 \\
\hline 11304 & 7.4737 & 35.4607 & 34.5273 & 26 & 7.450 \\
\hline 43.7 & $7 \cdot 4.727$ & 35.4513 & 34.3273 & 26 & 7.04716 \\
\hline $\begin{array}{l}3.3 .2 \\
3.3 .4\end{array}$ & $\begin{array}{l}704687 \\
7.4627\end{array}$ & $\begin{array}{l}33.4599 \\
33.4583\end{array}$ & $\begin{array}{l}34.3293 \\
34.3113\end{array}$ & $\begin{array}{l}26.1629 \\
26.1624\end{array}$ & $\begin{array}{l}7.4681 \\
7.4625\end{array}$ \\
\hline 27.8 & 704667 & $33.46: 3$ & 3403143 & 26.1635 & 704671 \\
\hline $\begin{array}{l}23 \cdot 6 \\
13 \circ 5\end{array}$ & $\begin{array}{l}7.4677 \\
7.466 ?\end{array}$ & $\begin{array}{l}33.4603 \\
33.4598\end{array}$ & $\begin{array}{l}3405132 \\
34.3992\end{array}$ & $\begin{array}{l}26 \\
26\end{array}$ & $\begin{array}{l}7.4585 \\
7.4675\end{array}$ \\
\hline 1104 & 704567 & 23.4594 & 34.2972 & 26.542 & 704585 \\
\hline $7 \cdot 8$ & 704527 & 3304618 & 34.2942. & $26: 1656$ & $704553^{\circ}$ \\
\hline 605 & 7.4597 & $3 z \cdot 4630$ & 34.3712 & 26.1566 & 7.4521 \\
\hline
\end{tabular}


AII $\$ 86$

DATE: $75 \%$ 1 8 C

LOHO NOO 2 INSTO NCO 2

TIME CONSTO = 30.0

r 423305 N 6851.7 H

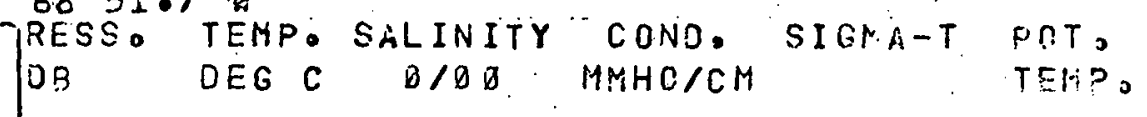

294

201.2

192.2

184.6

177.1

16909

i 61.9

$15 E_{0}$ ?

146.4

138.5

131.5

123.0

116.5

103.6

191.2

94.1

ES.2

77.7

70.4

6503

5902

51.9

$43 \circ 6$

35.7

30.5

2206

15.5

7.8

702
$7.839734 .2663 \quad 3504746 \quad 26.7419$

$7.841734 .2535 \quad 35.4726 \quad 26.7354$

$7.853234 .236135 .4535 \quad 26.71 \leqslant 2$

$7084223401914^{\prime \prime 3503986 ~ 26068 ? 3 ~}$

$7.829734 .136235 .3326 \quad 26.6413$

$7085923401183 \quad 3503396 \quad 260 \in 230$

$7.8652 \quad 3409518 \quad 350 ? 796 \quad 2605659$

$7.617734 .9156 \quad 35.2937 \quad 26.5517$

$706712 \quad 33.9718 \quad 3503229 \quad 2605355$

$70568233091173403719 \quad 2605032$

$7.4327 \quad 33.8547 \quad 34.693126 .4779$

$7.5457330 .91653407561 \quad 2504317$

8.475233 .878935065112605423

$8.6727: 33.8671 \quad 35.8159 .26 .3 .81$

$305652 \quad 3308176 \quad 3506531 \quad 2602810$

$30109733063513506316 \quad 26.2972$

7.641733 .5904340533126 .1730

$7.5522 \quad 33.468934 .4292 \quad 2601565$

$7054173304758 \quad 3404142 \quad 2601653$

$7.5372 \quad 33.4718 \quad 34.494226 .16 ? 5$

$7.5532 \quad 3304762 \quad 3404 ? 62 \quad 26016 ? 7$

$7.561733 .47613404242 \quad 2601624$

$7.358733 .4733 \quad 34.4152$ 26.1.25

$70558733047553404142 \quad 260.520$

$7.559233 .4736 \quad 34.4172 \quad 26$ ०15:3

$7.5472 .33 .4728 \quad 34.3952 \quad 25.1613$

$705552 \quad 3304739 \quad 3404091 \quad 2601815$

7.543733 .474734 .38312601659

$7.547733 .4763 \quad 34.532126 .1646$
7.2227

$7 \cdot 253 x$

7 a 8374

702272

$7 \cdot 8154$

702.455

702524

$7 \cdot 8956$

706691

705573

$7.423 ?$

$70 \equiv 36 \%$

i. 04567

8.6549

So55e?

ह. 135

7,636

705570

7 도 311

7.5341

705576

$70=589$

$70557 \%$

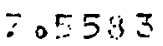

7 a 55.4

7.521

$70=56 i$

$70=45=?$

7 . 
AII 456

DATE:

ST. NO. 2144

LGIO NOO

$75: \cdots \cdots$

8 .

TIME CONSTO =

1 INST. NO.

2.

42 2200 N

PRESS. TEMPO SALINITY CONDO SIGMA-T POT.
DE DEG C DIGO MMHO/CM

235.

$2 \times 1.2$

$2240 \pm$

$217 \cdot 8$

21100

20200

$19.7 \cdot 2$

165.5

178.5

172.1

164.8

157.7

143.6

139.4

129.8

$12 \pi \cdot 6$

19705

13000

$52 \cdot 3$

44 o

7602

$63 \cdot 5 j$

$57 \circ$ ?

4500

39.2

$\therefore 9.7$

19.7

$7 \cdot 2$
$70149234.5362 \cdots$

7.137734 .6332

70103734.0193

7.13234 .5168

7.085734 .0115

7.016323400900

$7.036233 . \$ 667$

$7 \cdot 055233.9426$

6.833733 .836

6.714735 .07447

6.663233 .7973

6.602733 .6708

$6.594733: 6499$

$6.6897 \quad 33.6152$

$7.621233: 5945$

6.8917233 .4864

$7.2917 \cdot 37.4722$

7.417733 .4569

7.6547

7.6282

33.4462

34.6424

34.6354

34.5935

3405335

$34 \cdot 5655$

3405255

34.4565

34.4136

3401298

3309679

33.6850

33.7951

$3: 07651$

$3 \leftleftarrows .8065$

$34: 2857$

33.8669

$34: 124$

34.2954

34.5362

7.1722

33.2932

34.4212

7.1372

33.2518

33.9327

$3 \overline{5} 0769$

$7 \cdot 1152$

33.1972

7.1262

7.1157

$3 \pm .1942$

उज:7748

33.1907

33.773

2606515

2605555

2606526

2606514

$26 \cdot 6491$

2.6 .6437

$26 n 6213$

2606966

$26 \div 52.31$

$26.49: 4$

26.4678

26.4471

26.4317

$26.59 \pi$

$26 \% 3 ? 38$

$26 \cdot 2.226$

26.2799

26.01677

$25 \% 1242$

26.3379

$26 \circ 5439$

$26003 \leq 9$

$26: 03 \geqslant 9$

3307553

25.09952

7.111733 .1863

32.7498

70133733.1819

33.7378

25.5993

25.5931

$25.595 a$

$7.1242 \quad 3 \Xi 01784$

3507427

25.9398
701211

701193

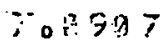

70.858

7.0733

70.473

7.0212

‥59ग.9

608173

607.120

606513

605915

605843

$5,671 \mathrm{j}$

广०12?

608821

7.1547

T.411]

706593

$7 \circ 625 ?$

$70: 531$

701043

701150

$701 ? 47$

70.1150

701118

$70 \therefore 18$

70.1254 
(.) AII $\$ 86$

\section{DATE:}

?

75. 1 . 3

ST. NO. 2149

LOHIO NOD 1

TIME CONST:" =

INST. NO.

2

42304 N $6932.35 \mathrm{~K}$

\begin{tabular}{|c|c|c|c|c|c|}
\hline $\begin{array}{l}\text { RESS : } \\
D B\end{array}$ & $\begin{array}{l}\text { TEMP: } \\
\text { DEG C }\end{array}$ & $\begin{array}{c}\text { SALINITY } \\
\cdot 0 / 03:\end{array}$ & $\begin{array}{l}\text { CONDO } \\
\text { MMHO/CM }\end{array}$ & $S I G H \dot{A}-T$ & $\begin{array}{l}\text { POT. } \\
\text { TERPD }\end{array}$ \\
\hline$\cdots$ & - & & $\cdots$ & $\cdots$ & $\cdots$ \\
\hline $\begin{array}{l}209.4 \\
204.3\end{array}$ & $\begin{array}{l}701447 \\
701432\end{array}$ & $\begin{array}{l}2409390 \\
34.0396\end{array}$ & $\begin{array}{l}34.6374 \\
34.6344\end{array}$ & $\begin{array}{l}26 \circ \leqslant 531 \\
26 \circ 6538\end{array}$ & $\begin{array}{l}701283 \\
701273\end{array}$ \\
\hline 15609 & 7.1327 & 34.9372 & 34.6194 & 26.6633 & $70217 ?$ \\
\hline 89.5 & 7.1217 & 34.2397 & 34.6304 & 26.6557 & 701360 \\
\hline 182.9 & 7.9472 & 33.9959 & 34.4985 & $26.54 ? 7$ & 709332 \\
\hline $175 \circ 5$ & 6.0327 & $-3 x ; 9224$ & $34 .: 256$ & 26.6335 & 6.5194 \\
\hline $1 \in 8.9$ & 608732 & 3303800 & 34.2337 & $260 \leq 754$ & $60 \% 607$ \\
\hline $16 ?$ & 342 & $33.8151^{\circ}$ & 3408928 & 395 & $607.7 ? 4$ \\
\hline 155.4 & $6 \cdot 7$ & 32.7759 & 34.8458 & 26.5353 & 6.7675 \\
\hline 148.5 & 6.8292 & 33.07373 & 34.2528 & 26.4591 & 6081.85 \\
\hline & $\begin{array}{l}6.9 .427 \\
6.578 ?\end{array}$ & $\begin{array}{l}3306989 \\
33.6761\end{array}$ & $\begin{array}{l}34.1077 \\
34: 1237\end{array}$ & $\begin{array}{l}2604156 \\
26.4938\end{array}$ & $\begin{array}{l}505327 \\
5.5683\end{array}$ \\
\hline 127.2. & 7.382 & 33.6543 & 34.1367 & 2605874 & $E_{0} 5994$ \\
\hline 19.7 & 70.422 & 3306522 & 3401526 & 260.723 & 7.034 \\
\hline $130 ?$ & 7.2137 & 33.6984 & 34.2625 & 26.2152 & $7 \cdot 2 \pi \leq ?$ \\
\hline$\underline{Q} S_{3} \dot{i}$ & 704762 & 33.5502 & 3404433 & 2602327 & 704692 \\
\hline 99.2 & 7.4767 & 33.5354 & 34.3963 & 2601975 & 704794 \\
\hline $5 ? 20$ & $7: 5767$ & 33.4783 & 34.4572 & 2604619 & 7.571 .7 \\
\hline 85.2 & 705877 & 33.4428 & 34.4312 & 2601326 & 705827 \\
\hline $7 ? \cdot 7$ & 7.5947 & 3504148 & 34.4382 & 26.1396 & 705984 \\
\hline 7906 & 7.4452 & 33.3544 & 34.2154 & 26.3874 & 7.4425 \\
\hline 62.5 & 7.3972 & 33.3371 & 3401544 & 2605766 & 70554 \\
\hline & 7.02467 & $3 z .2780$ & $3 \geq 096 \Xi 6$ & 2608511 & 7. $0 ? 445$ \\
\hline 43.5 & 7.1542 & 32.2365 & 33.8497 & 26.2314 & $7 \cdot 5527$ \\
\hline 4108 & 701232 & 33.2268 & 3307788 & 2603280 & $\pi_{0} 1193$ \\
\hline .5 & $70 \leq 177$ & 3302261 & 3307927 & 2600232 & 70.117 \\
\hline 27.4 & 7.1192 & 33.2243 & 35.7817 & $26 \cdot 3281$ & 701135 \\
\hline 1906 & 701357 & 33.2241 & $33: 7737$ & 2600333 & 701368 \\
\hline 11.4 & 7.3977 & 33.2238 & 3507.627 & $26: 0291$ & 709955 \\
\hline
\end{tabular}




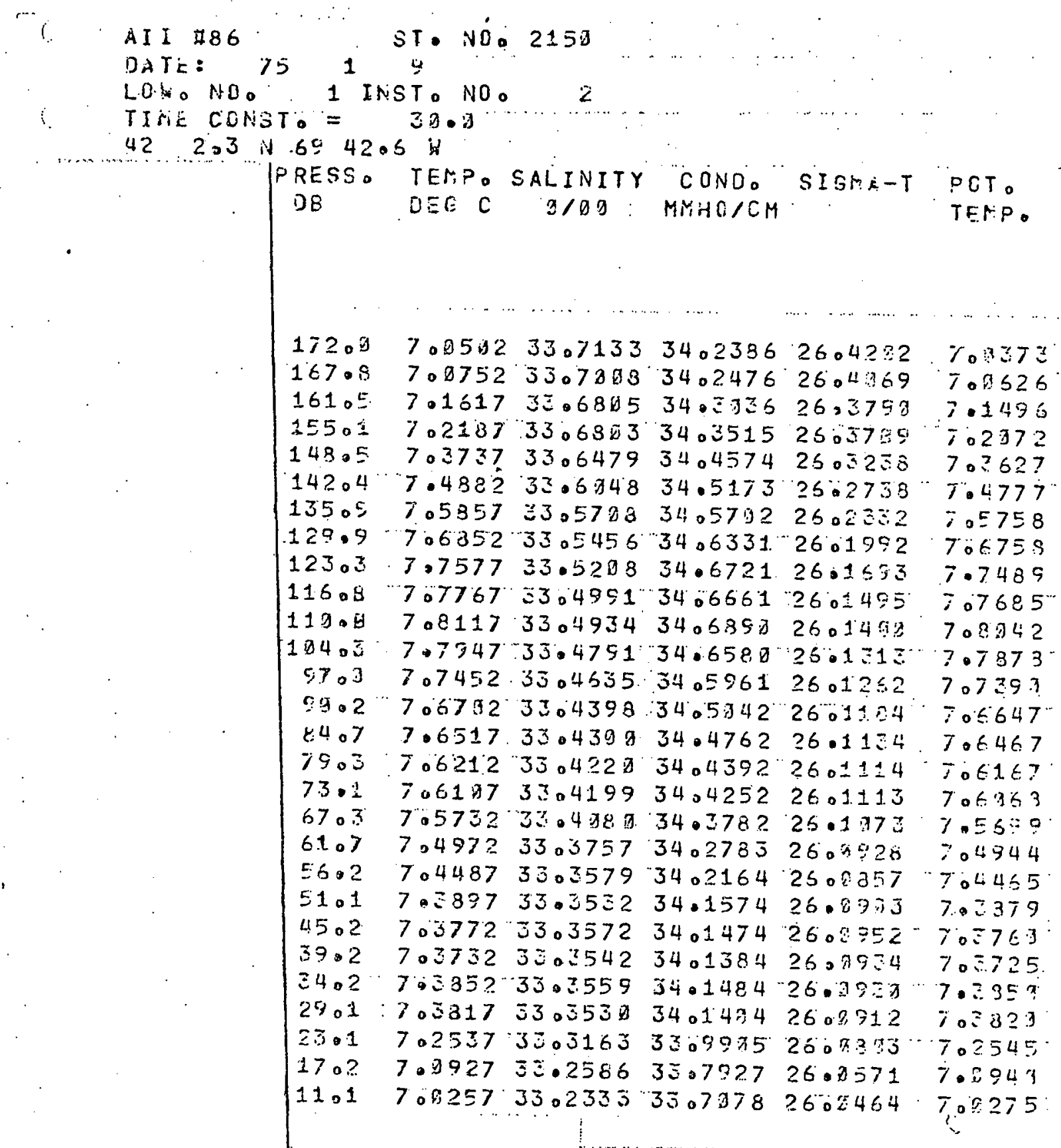




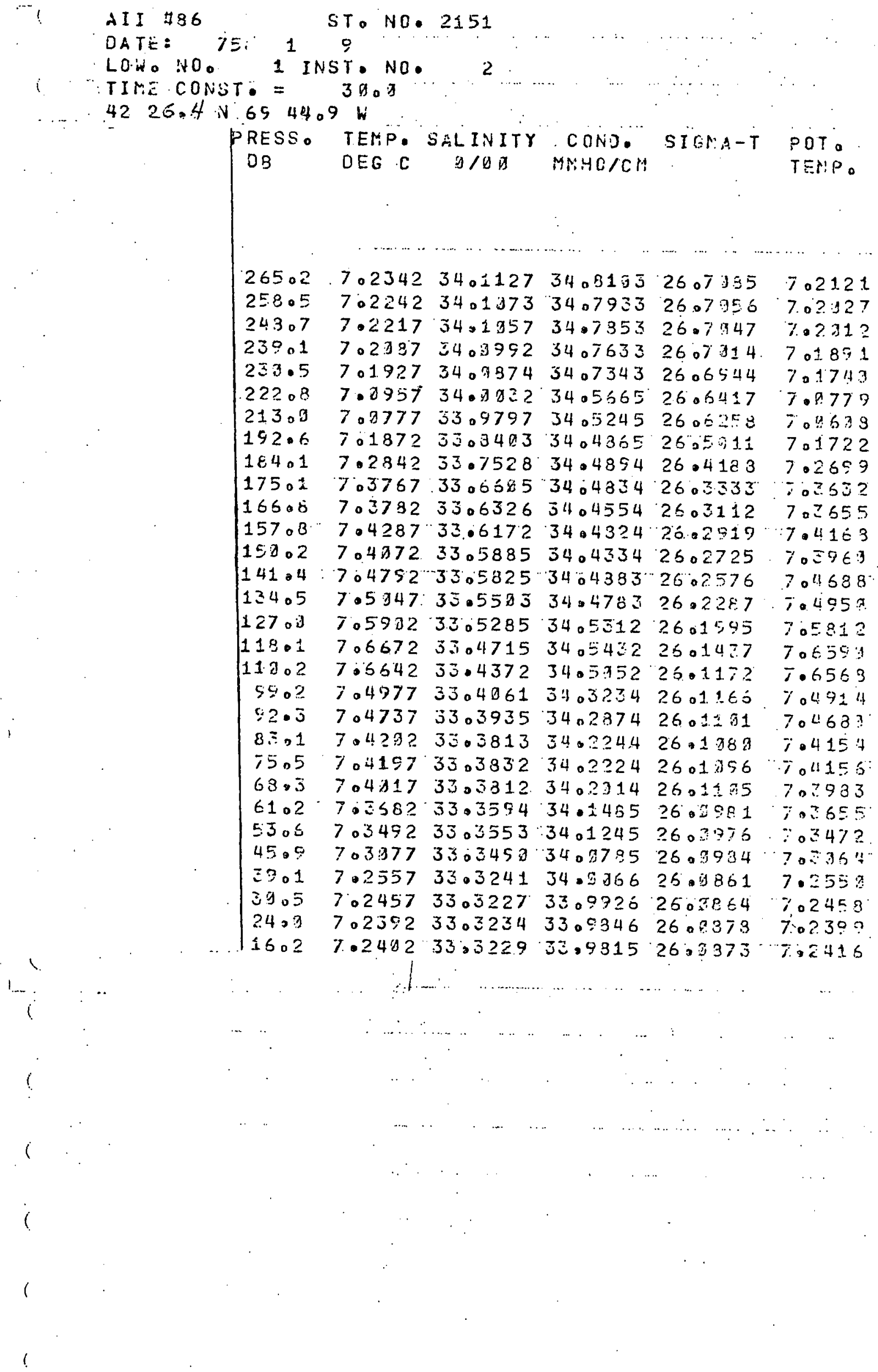




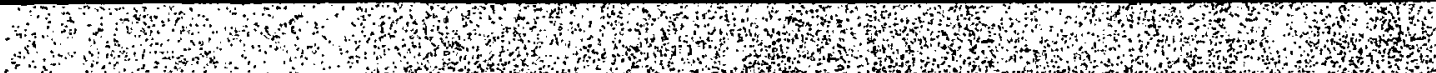

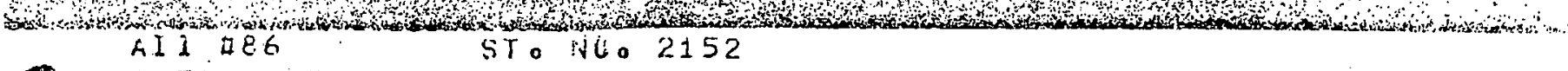

DATE: TEL I II: LOHO NOO INSTO NOO 2

TIME CONSTO = $30_{0} D$

9245.5 N 6858.1 W

PRESS. TEMPO SALINITY CONDO SIGFA-T POT.
DE DEE C EIOJ. HHHC/CH

\begin{tabular}{|c|c|c|c|c|c|}
\hline 215.4 & 7.5877 & 34.00670 & 35.6660 & $26 \cdot 6.2 ? 3$ & 7.569 \\
\hline 211.5 & 7.5787 & 34.0658 & 35.9550 & $26 \cdot 62=6$ & $\bar{t} \cdot 561 z$ \\
\hline 1500 & 705497 & 3400495 & 3500110 & $26.6 \pm 39$ & $705 \Xi 2 ?$ \\
\hline $199 \cdot 8$ & $7 \circ 5257$ & 34.8313 & 3405709 & 26.67 .32 & 705695 \\
\hline 3.2 & 7.4582 & $35 \cdot 5850$ & 34.6671 & $26: 557$ & 7.4425 \\
\hline 7.2 & 7.4277 & 33.9632 & 3408131 & 26.5637 & $70412^{\circ}$ \\
\hline 1.6 & 7.4192 & $3 z 05384$ & 34.7982 & $26 \% 5455$ & $704: 349$ \\
\hline & 7.4537 & $33 \cdot 541$ & $\Xi 4.7771$ & $26: 51: 6$ & $7.44 \pi$ \\
\hline 12 & 7.4877 & 33 & 4.7631 & $2604 \% 3$ & 704746 \\
\hline $62 \cdot 5$ & 7.7962 & 33.8168 & 3405999 & 260.279 & 7.78 \\
\hline $\begin{array}{l}156.6 \\
150.1\end{array}$ & $\begin{array}{l}7.6792 \\
7.9397\end{array}$ & $\begin{array}{l}33 \cdot 7916 \\
3307480\end{array}$ & $\begin{array}{l}35.0478 \\
35.318\end{array}$ & $\begin{array}{l}26.36 \div 9 \\
26.3253\end{array}$ & $\begin{array}{l}7.067 \% \\
7009 ? 1\end{array}$ \\
\hline .9 & 7.51 บ1 2 & 33.07135 & 34.5978 & $26.0=952$ & $7.85 .5 ?$ \\
\hline$=7.0$ & $7 \cdot 8477$ & 33.6807 & 34.5975 & $26 \cdot 285.6$ & $7 \bullet \varepsilon 374$ \\
\hline 1.4 & $7.85 \pm 2$ & 33.5999 & 34.8329 & 26.2177 & 7 . 8416 \\
\hline 4 & 7.8257 & Zこ & 34.7890 & 26.2959 & 7.8167 \\
\hline & $7 \cdot 7542$ & $3=5281$ & $34 \cdot 6851$ & $26 \cdot 1741$ & 7.7553 \\
\hline 8 & 7.72 & 33.5171 & 54.6341 & 26.1713 & $70715:$ \\
\hline $59 \cdot 3$ & $7.697 \%$ & 32.4909 & .5341 & $26 \cdot 1.545$ & 7 atgen \\
\hline $01, \bar{E}$ & 7.7117 & 33.4867 & 34.5341 & $26 \cdot 1445$ & $7 \cdot 7.051$ \\
\hline 55 & 7.6912 & 33.4709 & 34.5541 & 26.01 .98 & 706852 \\
\hline 89 & 7.7662 & 3504759 & $34 \circ 6230$ & 26.01329 & 70.7607 \\
\hline 83 & $7 \cdot 7352$ & $45 \Xi 5$ & 34.5451 & $26 \cdot 1241$ & $7 \cdot 730.3$ \\
\hline 76.6 & $y_{0} \in 712$ & 33.4496 & 34.5881 & 2601255 & $7_{0} \in 679$ \\
\hline $70 \cdot 5$ & 7.7532 & 35.04584 & 34.5871 & 26.1211 & 7.7495 \\
\hline 65.0 & $7 \cdot 7.932$ & $32 \cdot 4114$ & 34.4961 & $26 \cdot 15: 14$ & $\overline{7} .7991$ \\
\hline 5801 & 7.6377 & $3004075^{\circ}$ & 3404312 & $2605: 77$ & $\pi 0635 ?$ \\
\hline $52 \cdot 5$ & 7.6387 & 33.4871 & 34.4292 & 26.00973 & 7 ot $z \leq 3$ \\
\hline 46.8 & 7.6327 & 33.4916 & 34.4172 & $26: 0957$ & $7 \cdot 6523$ \\
\hline 40.5 & 7.6357 & 33.4086 & 54.4152 & 2608526 & $\bar{T}_{0} \in Z 4 \%$ \\
\hline$\Xi 3.7$ & 7.6412 & 33.3985 & $34.4151^{\circ}$ & 26.6992 & $70 \in 411$ \\
\hline 27.4 & 7.6357 & $33 \cdot 5917$ & 34.4911 & 26.0856 & $70 \leqslant 36 ?$ \\
\hline 21.2 & 705352 & 33.5687 & 34.3322 & 26.6748 & 705363 \\
\hline $16 \cdot 5$ & 7.5777 & 32 직 & $340 \geq 172$ & 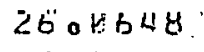 & 705793 \\
\hline 1005 & $7 \cdot 5777$ & $32 \cdot 3551$ & $34: 3982$ & $26.5 E 2$ & $7.57: 3$ \\
\hline
\end{tabular}




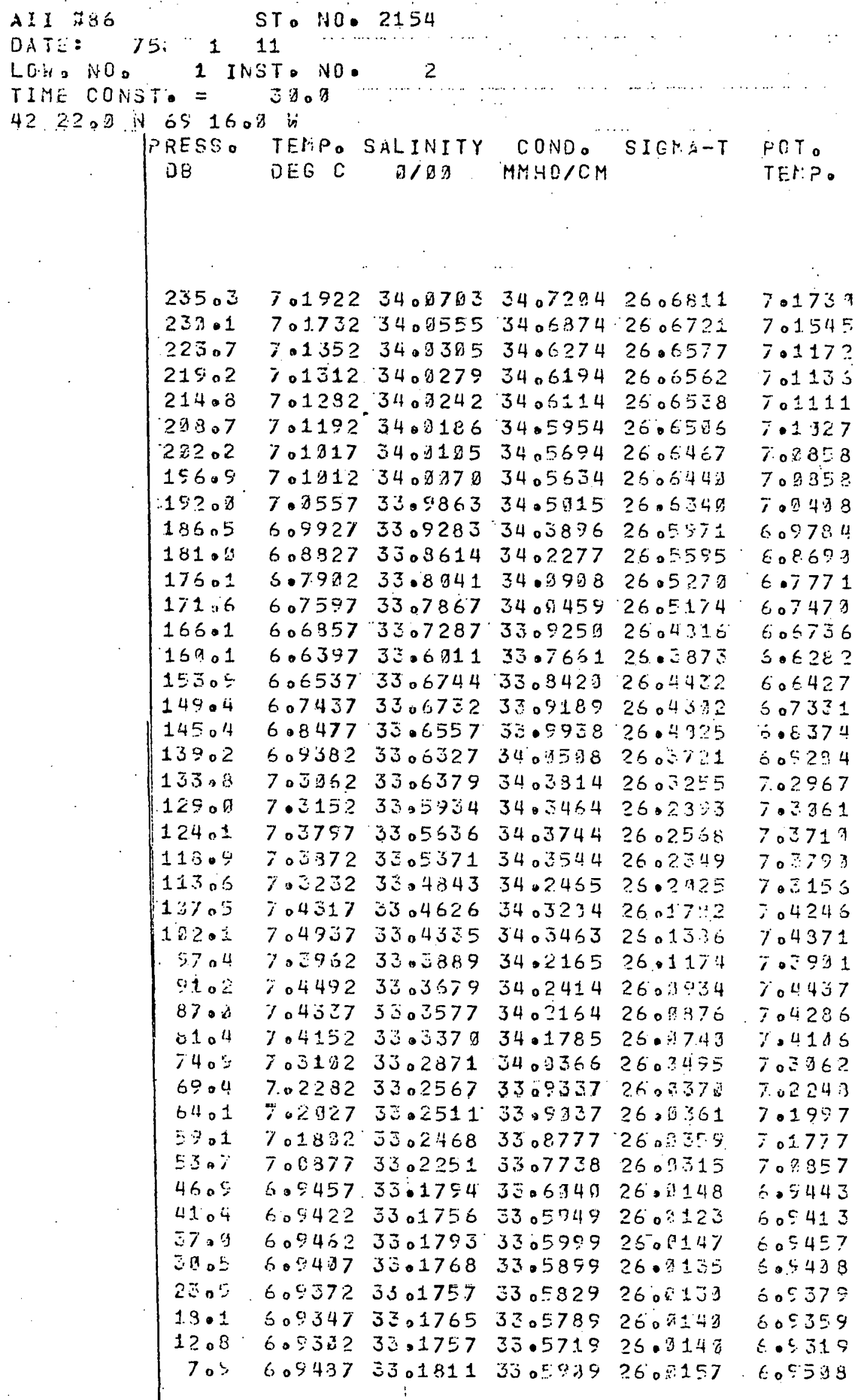


AII $\# 86$

ST. NOD 2155

OATE: 75112

LOHD NOO 1 INSTO NOO

2

TIHE CDNSTO = 3 O.D

4213.06 N:65 26.5 W

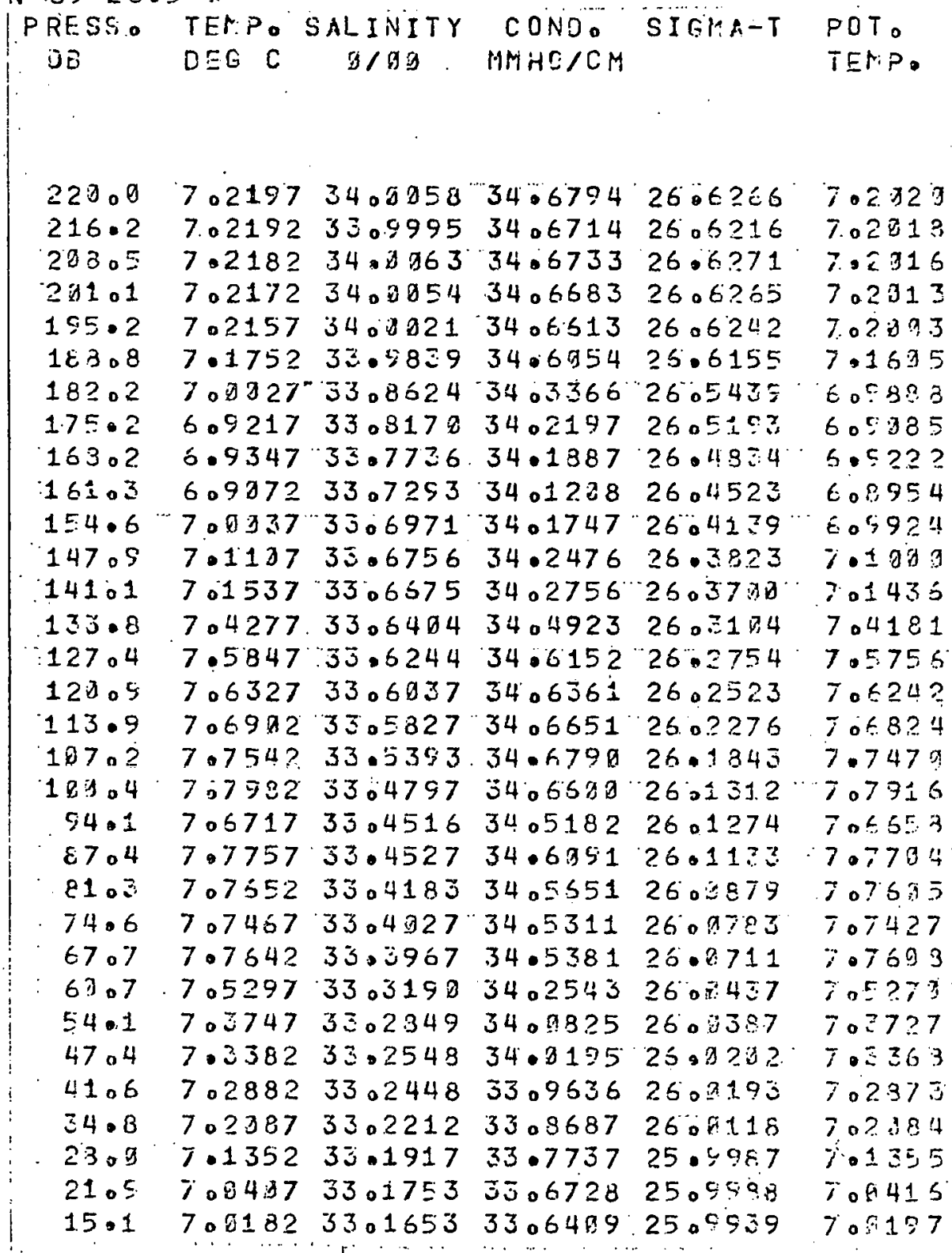


AII I86 STONO. 2156

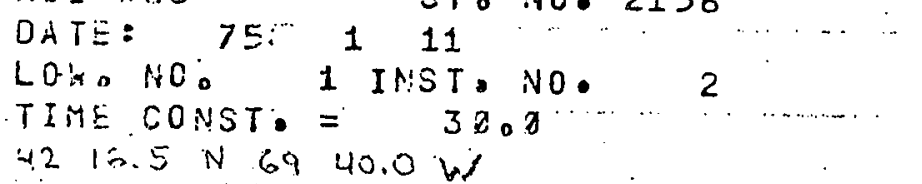

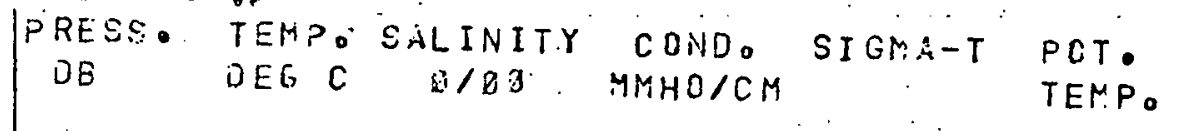

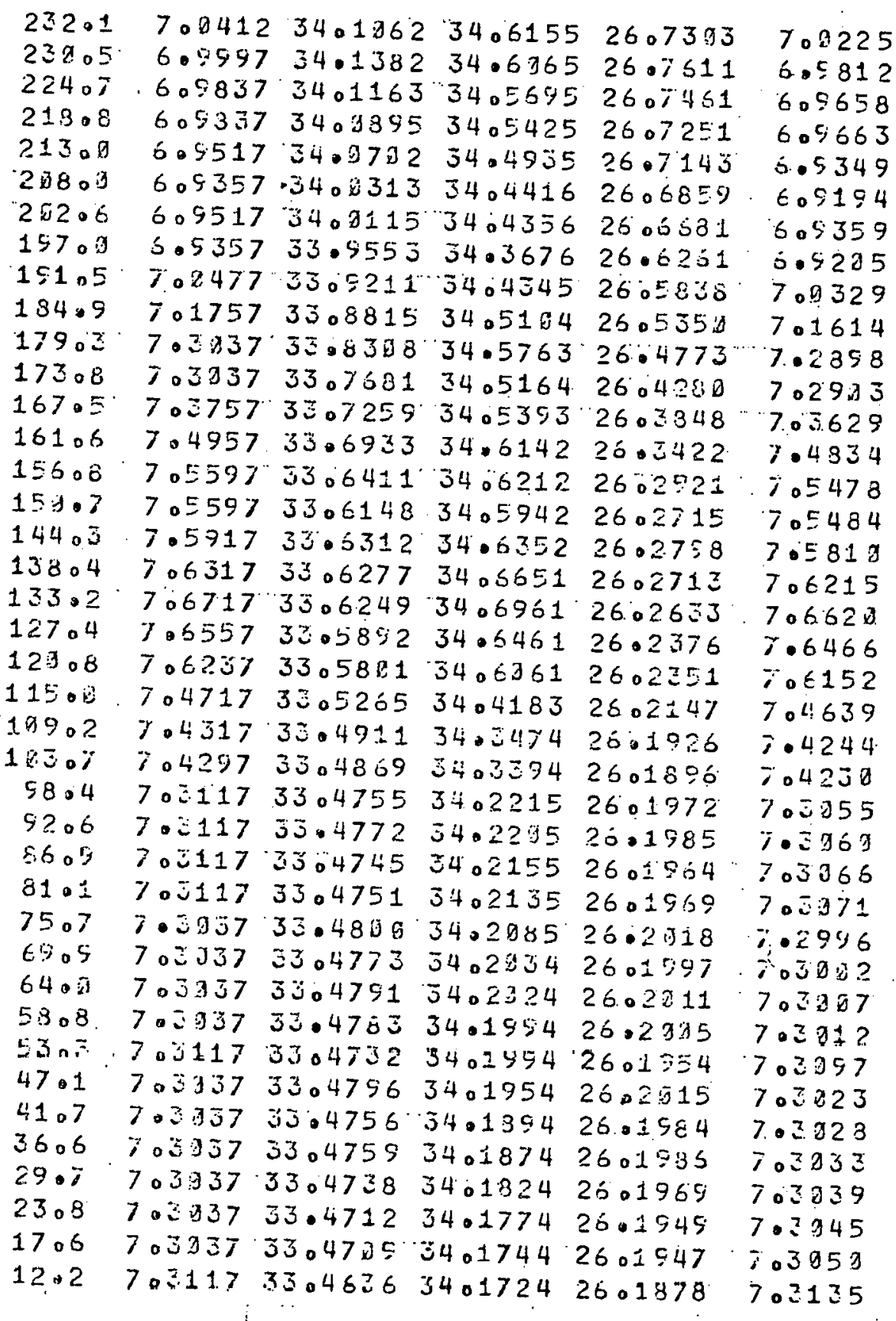


APPENDIX 3

Hydrographic Discrete Sample Data 
Station 212?

$1 / 4 / 75$

G.M.T. 16.7

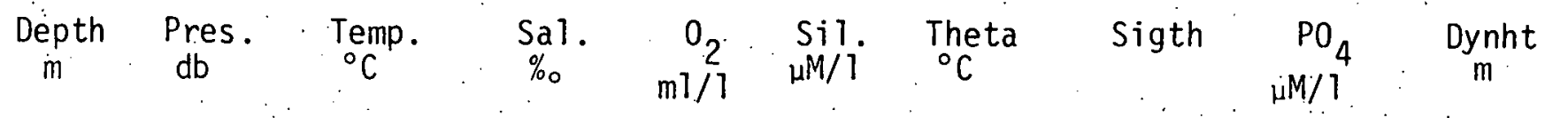

\begin{tabular}{|c|c|c|c|c|c|c|c|c|c|}
\hline 0 & & . & 33.464 & 6.25 & 10.20 & & & .87 & \\
\hline 5 & 5 & 7.690 & 33.476 & 6.47 & 9.13 & 7.690 & 26.144 & .82 & .009 \\
\hline 10 & 10 & 7.710 & 33.468 & 6.24 & 8.84 & 7.709 & 26.135 & .82 & .019 \\
\hline 20 & 20 & 7.730 & 33.463 & 6.19 & $9.52:$ & 7.728 & 26.129 & .89 & .038 \\
\hline 35 & 35 & 7.690 & 33.465 & 6.16 & 8.93 & 7.687 & 26.136 & $.97^{\circ}$ & .066 \\
\hline 50 & 50 & 7.740 & 33.465 & 6.18 & 8.84 & 7.735 & 26.129 & .92 & .095 \\
\hline 74 & 74 & 7.720 & 33.471 & 6.17 & 9.13 & 7.713 & 26.137 & 1.0 & .141 \\
\hline 98 & & . .. & 33.441 & 6.14 & 9.22 & & & 1.02 & \\
\hline 99 & 100 & 7.770 & 33.484 & 6.18 & 8.84 & 7.760 & 26.141 & .95 & .189 \\
\hline 121 & 122 & 7.670 & 33.460 & & 8.84 & 7.658 & 26.136 & 1.05 & .237 \\
\hline 124 & 125 & 7.760 & 33.486 & 6.15 & 8.54 & 7.748 & 26.144 & .95 & .236 \\
\hline 144 & 145 & 7.800 & 33.495 & 6.10 & .8 .54 & 7.786 & 26.145 & 3.05 & .275 \\
\hline 149 & 150 & 7.920 & 33.637 & 5.02 & 12.53 & 7.905 & 26.239 & 1.14 & .284 \\
\hline 168 & 169 & 7.570 & 33.671 & 4.76 & 13.40 & 7.554 & 26.317 & 1.3 & .318 \\
\hline 189 & 190 & 6.920 & 33.746 & 4.68 & 15.34 & 6.903 & 26.466 & 1.25 & .354 \\
\hline 204 & 205 & 7.080 & 34.026 & 4.24 & 19.23 & 7.061 & 26.665 & 1.48 & 376 \\
\hline $223^{\circ}$ & 224 & 7.260 & 34.112 & 4.19 & 18.64 & 7.239 & 26.708 & 1.56 & .403 \\
\hline 232 & 234 & 7.360 & 34.178 & 4.09 & 18.55 & 7.338 & 26.746 & 1.59 & .416 \\
\hline 242 & & & 34.184 & 4.04 & 18.74 & & & 1.63 & \\
\hline 257 & 253 & 7.380 & 34.188 & 3.94 & 18.64 & 7.356 & 26.751 & 1.67 & .441 \\
\hline
\end{tabular}




\section{SPECIAL NISKIN CAST}

Station 2122

\section{$\underline{1 / 4 / 75}$}

\begin{tabular}{ccc} 
Corr Depth & Temp. ${ }^{\circ} \mathrm{C}$ & Sal.\%。 \\
\hline 2 & 7.49 & 33.399 \\
19 & 7.45 & 33.399 \\
39 & 7.51 & 33.410 \\
67 & - & 33.451 \\
96 & - & 33.459 \\
125 & 7.76 & 33.483 \\
163 & 7.63 & 33.631 \\
192 & - & 33.766 \\
221 & 7.12 & 34.060 \\
255 & 7.37 & no samp $1 \mathrm{e}$
\end{tabular}


STATION 2122

\section{NANSENS FROM BODMAN CASTS}

\section{SERIES VTB}

\begin{tabular}{lcccc} 
Wire Out & Depth (Calc.) & Temp. ${ }^{{ }^{\circ} \mathrm{C}}$ & $\begin{array}{l}\text { Nansen } \\
\text { Sal. } / 00\end{array}$ & $\begin{array}{l}\text { Bodman } \\
\text { Sal. } \% \text { oo }\end{array}$ \\
\hline Surface from S. W. line & & & 33.460 \\
$50^{\mathrm{F}}$ & 43 & 7.66 & 33.461 & 33.462 \\
50 & 88 & 7.63 & 33.416 & 33.424 \\
100 & 93 & 7.74 & 33.474 & 33.476 \\
175 & 162 & 7.64 & 33.699 & 33.695 \\
$175^{\mathrm{F}}$ & - & - & 33.663 & 33.663 \\
200 & 197 & 6.87 & 33.951 & 33.848 \\
$275^{\mathrm{F}}$ & - & - & 34.207 & 34.210 \\
275 & 263 & 7.42 & 34.200 & 34.109
\end{tabular}

$F=F i l$ tered Sample 
STATION 2122

NANSEN BODMAN CAST.

\section{SERIES MB}

\begin{tabular}{|c|c|c|c|c|}
\hline $\begin{array}{l}\text { Bodman Wire } \\
\text { Out }\end{array}$ & $\begin{array}{c}\text { Nansen } \\
\text { Depth Calc. }\end{array}$ & $\begin{array}{l}\text { Temp. } \\
{ }^{\circ} \mathrm{C}\end{array}$ & $\begin{array}{l}\text { Nansen } \\
\text { Sal. \% }\end{array}$ & $\begin{array}{l}\text { Bodman } \\
\text { Sal. } \% / 00\end{array}$ \\
\hline & & & & \\
\hline 0 & & & & $\begin{array}{l}33.359 \\
33.362\end{array}$ \\
\hline 40 & 37 & 7.50 & $\begin{array}{l}33.374 \\
33.379\end{array}$ & $\begin{array}{l}33.378 \\
33.379\end{array}$ \\
\hline 90 & 78 & 7.69 & 33.455 & $\begin{array}{l}33.455 \\
33.457\end{array}$ \\
\hline 125 & 115 & 7.71 & 33.448 & $\begin{array}{l}33.449 \\
33.452\end{array}$ \\
\hline 170 & 148 & 7.89 & $\begin{array}{l}33.632 \\
33.639\end{array}$ & $\begin{array}{r}33.507 \\
33.510\end{array}$ \\
\hline 185 & . & 6.96 & $\begin{array}{l}33.717 \\
33.721\end{array}$ & $\begin{array}{l}33.792 \\
33.792\end{array}$ \\
\hline 200 & 189 & 6.95 & $\begin{array}{l}33.805 \\
33.809\end{array}$ & $\begin{array}{l}\text { No } \\
\text { Sample }\end{array}$ \\
\hline 230 & - & - & $\begin{array}{l}34.041 \\
34.043\end{array}$ & $\begin{array}{l}34.062 \\
34.066\end{array}$ \\
\hline 260 & 246 & 7.36 & $\begin{array}{l}34.173 \\
34.178\end{array}$ & $\begin{array}{l}34.185 \\
34.188\end{array}$ \\
\hline
\end{tabular}




\section{ATLANTIS II CRUISE 86}

\section{Station 2123}

\section{$1 / 5 / 75$}

G.M.T. 20.0

\begin{tabular}{rcccccc}
$\begin{array}{c}\text { Depth } \\
\mathrm{m}\end{array}$ & $\begin{array}{c}\text { Pres. } \\
\mathrm{db}\end{array}$ & $\begin{array}{c}\text { Temp } \\
{ }^{\circ} \mathrm{C}\end{array}$ & $\begin{array}{c}\text { Sal } \\
\%\end{array}$ & $\begin{array}{c}\text { Theta } \\
{ }^{\circ} \mathrm{C}\end{array}$ & $\begin{array}{c}\text { Sigth } \\
\text { O }\end{array}$ & $\begin{array}{c}\text { Dynht } \\
\mathrm{m}\end{array}$ \\
\hline 3 & 3 & 7.270 & 33.348 & 7.270 & 26.103 & .000 \\
50 & 50 & 7.300 & 33.358 & 7.295 & 26.108 & .091 \\
74 & 74 & 7.400 & 33.388 & 7.393 & 26.118 & .137 \\
98 & 99 & 7.440 & .33 .414 & 7.431 & 26.133 & .183 \\
123 & 124 & 7.510 & 33.428 & 7.498 & 26.134 & .231 \\
143 & 144 & 7.510 & 33.474 & 7.496 & 26.170 & .269 \\
152 & 153 & 7.290 & 33.557 & 7.276 & 26.267 & .286
\end{tabular}




\section{ATLANTIS II CRUISE 86}

Station 2128

$$
1 / 6 / 75
$$

G.M.T. 12.7

\begin{tabular}{|c|c|c|c|c|c|c|}
\hline $\begin{array}{c}\text { Depth } \\
\mathrm{m}\end{array}$ & $\begin{array}{c}\text { Pres. } \\
\text { db }\end{array}$ & $\begin{array}{c}\text { Temp. } \\
{ }^{\circ} \mathrm{C}\end{array}$ & $\begin{array}{c}S a 1 . \\
\%_{0}\end{array}$ & $\begin{array}{l}\text { Theta } \\
{ }^{\circ} \mathrm{C}\end{array}$ & Sigth & $\begin{array}{c}\text { Dynht } \\
\mathrm{m}\end{array}$ \\
\hline 0 & 0 & 7.270 & 33.360 & 7.270 & 26.113 & .000 \\
\hline 45 & 45. & 7.270 & 33.357 & 7.266 & 26.111 & $: 087$ \\
\hline 69 & 69 & 7.290 & 33.358 & $7: 284$ & 26.109 & .133 \\
\hline 94 & & & 33.359 & & & \\
\hline 119. & & & 33.360 & & & \\
\hline 144 & 145 & 7.380 & 33.518 & 7.366 & 26.223 & .275 \\
\hline 168 & 169 & 6.930 & 33.728 & 6.915 & 26.451 & .316 \\
\hline 193 & & & 33.943 & & & \\
\hline 218 & 219 & 7.250 & 34.106 & 7.229 & 26.704 & .392 \\
\hline 243 & 24.5 & 7.300 & 34.147 & $\cdot 7.277$ & 26.730 & .426 \\
\hline
\end{tabular}




\section{ATLANTIS II CRUISE 86}

\section{Station 2131}

\section{$\underline{1 / 6 / 75}$}

G.M.T. 14.0

\begin{tabular}{ccccccc}
$\begin{array}{c}\text { Depth } \\
\mathrm{m}\end{array}$ & $\begin{array}{c}\text { Pres. } \\
\mathrm{db}\end{array}$ & $\begin{array}{c}\text { Temp. } \\
{ }^{\circ} \mathrm{C}\end{array}$ & $\begin{array}{c}\text { Sal. } \\
\%\end{array}$ & $\begin{array}{c}\text { Theta } \\
{ }^{\circ} \mathrm{C}\end{array}$ & Sigth & $\begin{array}{c}\text { Dynht } \\
\mathrm{m}\end{array}$ \\
\hline 1 & 1 & 7.520 & 33.432 & 7.520 & 26.412 & .000 \\
10 & 10 & 7.640 & 33.467 & 7.639 & 26.354 & .015 \\
30 & 30 & 7.730 & 33.468 & 7.727 & 26.142 & .051 \\
70 & 70 & 7.750 & 33.476 & 7.743 & 26.137 & .127 \\
100 & 101 & 7.730 & 33.480 & 7.720 & 26.134 & .184 \\
130 & 131. & 7.720 & 33.734 & 7.707 & 26.107 & .242 \\
170 & 171 & 7.610 & 33.786 & 7.594 & 26.124 & .320
\end{tabular}




\section{ATLANTIS II CRUISE 86}

Station 2138

\section{$\underline{1 / 7 / 75}$}

G.M.T. 9.5

\begin{tabular}{rccccccccc}
$\begin{array}{c}\text { Depth } \\
\mathrm{m}\end{array}$ & $\begin{array}{c}\text { Pres. } \\
\mathrm{db}\end{array}$ & $\begin{array}{c}\text { Temp. } \\
{ }^{\circ} \mathrm{C}\end{array}$ & $\begin{array}{c}\text { Sa1. } \\
\%\end{array}$ & $\begin{array}{c}\mathrm{O}_{2} \\
\mathrm{ml} / 1\end{array}$ & $\begin{array}{c}\text { Sil. } \\
\mu \mathrm{M} / 1\end{array}$ & $\begin{array}{c}\text { Theta } \\
{ }^{\circ} \mathrm{C}\end{array}$ & Sigth & $\begin{array}{c}\mathrm{PO}_{4} \\
\mu \mathrm{M} / 1\end{array}$ & $\begin{array}{c}\text { Dynht } \\
\mathrm{m}\end{array}$ \\
\hline 2 & 2 & 7.104 & 33.200 & 6.42 & 8.84 & 7.104 & 26.010 & 1.06 & .000 \\
12 & 12 & 7.090 & 33.200 & 6.59 & 8.84 & 7.089 & 26.012 & .94 & .020 \\
25 & 25 & 7.100 & 33.201 & 6.40 & 8.84 & 7.098 & 26.012 & .96 & .046 \\
48 & 48 & 7.340 & 33.321 & 6.46 & 8.84 & 7.336 & 26.073 & .95 & .092 \\
66 & 66 & 7.800 & 33.510 & 6.38 & 8.74 & 7.794 & 26.156 & .88 & .127 \\
84 & 85 & 7.790 & 33.515 & 6.19 & 8.64 & 7.782 & 26.162 & 1.00 & .161 \\
102 & 103 & 7.740 & 33.512 & 6.16 & 8.64 & 7.730 & 26.167 & .98 & .195 \\
120 & & & 33.523 & 6.13 & 8.64 & & & .97 & \\
136 & 137 & 7.730 & 33.517 & 6.08 & 8.16 & 7.717 & 26.173 & .87 & .259 \\
140 & 141 & 7.600 & 33.726 & 4.72 & 14.27 & 7.586 & 26.355 & 1.26 & .266 \\
154 & 155 & 7.730 & 33.687 & 4.96 & 13.50 & 7.715 & 26.306 & 1.28 & .291 \\
169 & 170 & 6.930 & 33.803 & 4.50 & 16.99 & 6.915 & 26.510 & 1.36 & .316 \\
173 & 174 & 7.180 & 33.793 & 4.43 & 14.57 & 7.164 & 26.468 & 1.42 & .322 \\
191 & 192 & 7.030 & 33.924 & 4.43 & 17.19 & 7.012 & 26.591 & 1.39 & .350 \\
209 & 210 & 7.150 & 34.049 & 4.34 & 17.77 & 7.130 & 26.673 & 1.47 & .376 \\
218 & 219 & 7.190 & 34.083 & 4.19 & 18.35 & 7.169 & 26.695 & 1.45 & .389 \\
227 & 229 & 7.270 & 34.077 & 4.18 & 18.35 & 7.248 & 26.679 & 1.40 & .402 \\
236 & & & 34.160 & 4.12 & 18.35 & & & 1.47 & \\
245 & 247 & 7.360 & 34.182 & 4.08 & 18.64 & 7.336 & 26.749 & 1.47 & .427 \\
250 & 252 & 7.370 & 34.187 & 4.07 & 18.64 & 7.346 & 26.751 & 1.52 & .434
\end{tabular}


STATION 2138

BODMAN CASTS

SERIES MB

\begin{tabular}{rcccc} 
Wire Out & $\begin{array}{c}\text { Nansen Calc. } \\
\text { Depth }\end{array}$ & $\begin{array}{c}\text { Temp. } \\
{ }^{\circ} \mathrm{C}\end{array}$ & $\begin{array}{c}\text { Nansen } \\
\text { Sa1. } \% 00\end{array}$ & $\begin{array}{l}\text { Bodman } \\
\text { Sa7. } \%\end{array}$ \\
\hline 10 & & & & \\
100 & 4 & 7.132 & 33.238 & 33.237 \\
190 & 93 & 7.76 & 33.516 & 33.511 \\
220 & - & - & 33.883 & 33.980 \\
250 & - & - & 34.055 & 34.114 \\
280 & 238 & 7.29 & 34.150 & 34.187 \\
& 259 & 7.36 & 34.189 & 34.184
\end{tabular}

BODMAN CASTS

SERIES VTB

Surface from S. W. line

(33.196)

$\begin{array}{ccccc}50 & 44 & 7.70 & 33.517 & \\ 100 & 94 & 7.73 & 33.519 & 33.519 \\ 200 & 192 & 7.00 & 33.950 & 34.015 \\ 200 & 189 & 7.025 & 33.932 & 33.209 \\ 275 & 260 & 7.38 & 34.193 & 34.190 \\ 280 & - & - & 34.190 & 34.190\end{array}$




\section{ATLANTIS II CRUISE 86}

\section{Station 2144}

\begin{tabular}{|c|c|c|c|c|c|c|}
\hline & & & $\frac{\angle 8 / 75}{. T .11 .5}$ & & & \\
\hline $\begin{array}{c}\text { Depth } \\
\mathrm{m}\end{array}$ & $\begin{array}{c}\text { Pres. } \\
\mathrm{db}\end{array}$ & $\begin{array}{c}\text { Temp. } \\
{ }^{\circ} \mathrm{C}\end{array}$ & $\begin{array}{l}\text { Sal. } \\
\% \%_{0}\end{array}$ & $\begin{array}{l}\text { Theta } \\
{ }^{\circ} \mathrm{C}\end{array}$ & Sigth & $\begin{array}{c}\text { Dynht } \\
\mathrm{m}\end{array}$ \\
\hline 2 & 2 & 6.990 & 33.163 & 6.990 & 25.996 & .000 \\
\hline 33 & 33 & 6.990 & 33.174 & 6.987 & 26.005 & .063 \\
\hline 63 & 63 & 7.040 & 33.191 & 7.034 & 26.012 & .124 \\
\hline 94 & 95 & 7.650 & 33.444 & 7.641 & 26.126 & .185 \\
\hline 120 & 121 & 7.000 & 33.558 & 6.989 & 26.307 & .233 \\
\hline 148 & 149 & 6.640 & 33.680 & 6.627 & 26.451 & .280 \\
\hline 178 & 179 & 6.960 & 33.980 & 6.944 & 26.645 & .326 \\
\hline 207 & & & 34.024 & & & \\
\hline 225 & 227 & 6.610 & 34.027 & 6.590 & 26.730 & .392 \\
\hline 235 & 237 & 7.090 & 34.028 & 7.068 & 26.665 & .406 \\
\hline
\end{tabular}


ATLANTIS II CRUISE 86

Station 2146

$1 / 8 / 75$

G.M.T. 16.2

\begin{tabular}{rrrrrrr}
$\begin{array}{c}\text { Depth } \\
\mathrm{m}\end{array}$ & $\begin{array}{c}\text { Pres. } \\
\mathrm{db}\end{array}$ & $\begin{array}{c}\text { Temp. } \\
{ }^{\circ} \mathrm{C}\end{array}$ & $\begin{array}{c}\text { Sal. } \\
\% \text { o }\end{array}$ & $\begin{array}{c}\text { Theta } \\
{ }^{\circ} \mathrm{C}\end{array}$ & Sigth & $\begin{array}{c}\text { Dynht } \\
\mathrm{m}\end{array}$ \\
\hline 0 & 0 & 7.460 & 33.390 & 7.460 & 26.110 & .000 \\
32 & 32 & 7.450 & 33.390 & 7.447 & 26.112 & .062 \\
64 & 64 & 7.480 & 33.396 & 7.474 & 26.112 & .123 \\
107 & 108 & 7.470 & 33.399 & 7.460 & 26.117 & .206 \\
139 & 140 & 7.680 & 33.606 & 7.667 & 26.250 & .266 \\
182 & 183 & 7.030 & 33.853 & 7.013 & 26.535 & .339 \\
214 & 215 & 7.040 & 33.979 & 7.020 & 26.634 & .387 \\
235 & 237 & 7.110 & 34.055 & 7.088 & 26.684 & .417 \\
257 & 259 & 7.130 & 34.059 & 7.106 & 26.685 & .448
\end{tabular}


ATLANTIS II CRUISE 86

Station 2147

$1 / 8 / 75$

G.M.T. 18.7

\begin{tabular}{ccccccc}
$\begin{array}{c}\text { Depth } \\
\mathrm{m}\end{array}$ & $\begin{array}{c}\text { Pres. } \\
\mathrm{db}\end{array}$ & $\begin{array}{c}\text { Temp. } \\
{ }^{\circ} \mathrm{C}\end{array}$ & $\begin{array}{c}\text { Sal. } \\
\% \circ\end{array}$ & $\begin{array}{c}\text { Theta } \\
{ }^{\circ} \mathrm{C}\end{array}$ & Sigth & $\begin{array}{c}\text { Dynht } \\
\mathrm{m}\end{array}$ \\
\hline 10 & 10 & 6.998 & 33.368 & 6.997 & 26.156 & .000 \\
30 & 30 & 7.403 & 33.366 & 7.400 & 26.099 & .038 \\
50 & 50 & 7.421 & 33.373 & 7.416 & 26.102 & .077
\end{tabular}




\section{ATLANTIS II CRUISE 86}

\section{Station 2149}

\section{$1 / 8 / 75$}

\section{G.M.T. 23.0}

\begin{tabular}{|c|c|c|c|c|c|c|}
\hline $\begin{array}{c}\text { Depth } \\
\text { m } \\
\end{array}$ & $\begin{array}{c}\text { Pres } \\
\mathrm{db}\end{array}$ & $\begin{array}{c}\text { Temp. } \\
{ }^{\circ} \mathrm{C} \\
\end{array}$ & $\begin{array}{c}\text { Sal. } \\
\%\end{array}$ & $\begin{array}{l}\text { Theta } \\
{ }^{\circ} \mathrm{C}\end{array}$ & Sigth & $\begin{array}{c}\text { Dynht } \\
-\mathrm{m} \\
\end{array}$ \\
\hline 5 & 5 & 7.070 & 33.228 & 7.070 & 26.037 & 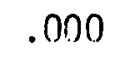 \\
\hline 26 & 26 & $7: 070$ & 33.228 & 7.068 & 26.037 & .042 \\
\hline 51. & 51 & 7.120 & 33.241 & 7.115 & 26.041 & .092 \\
\hline 82 & 83 & 7.450 & 33.369 & 7.442 & 26.096 & .153 \\
\hline 102 & 103 & 7.610 & 33.492 & 7.600 & 26.170 & .191 \\
\hline 128 & 129 & 7.150 & 33.640 & 7.138 & 26.351 & .238 \\
\hline .153 & 154 & 6.920 & 33.725 & 6.906 & 26.449 & .280 \\
\hline 184 & 185 & 6.980 & 33.977 & 6.963 & 26.640 & .328 \\
\hline 194 & 195 & 7.050 & 34.047 & .7 .032 & 26.685 & .342 \\
\hline 209 & 210 & 7.130 & 34.054 & 7.110 & 26.680 & .363 \\
\hline
\end{tabular}




\section{ATLANTIS II CRUISE 86}

STATION 2151

\section{$1 / 9 / 75$}

G.M.T. 7.0

\begin{tabular}{|c|c|c|c|c|c|c|c|c|c|}
\hline$\underset{\mathrm{m}}{\text { Depth }}$ & $\begin{array}{l}\text { Pres } \\
\mathrm{db}\end{array}$ & $\begin{array}{l}\text { Temp. } \\
{ }^{\circ} \mathrm{C}\end{array}$ & $\begin{array}{l}\text { Sal. } \\
0 / 00\end{array}$ & $\begin{array}{c}02 \\
\mathrm{~m} 1 / 1\end{array}$ & $\begin{array}{r}\mathrm{Sil} \\
\mu \mathrm{M} / 1\end{array}$ & $\begin{array}{l}\text { Theta } \\
{ }^{\circ} \mathrm{C} .\end{array}$ & Sigth & $\mathrm{MM}_{\mathrm{M}}^{\mathrm{P}}$. & $\underset{\mathrm{m}}{\mathrm{Dynth}}$ \\
\hline 1 & 1 & 7.440 & 33.304 & 6.44 & 8.64 & 7.440 & 26.045 & .93 & .000 \\
\hline 21 & 21 & 7.430 & 33.304 & 6.58 & 8.84 & 7.428 & 26.047 & .93 & .040 \\
\hline 42 & 42 & 7.450 & 33.305 & 6.43 & 8.84 & 7.446 & 26.045 & .95 & .081 \\
\hline 62 & 62 & 7.540 & 33.305 & 6.49 & 10.10 & 7.534 & 26.033 & .95 & .121 \\
\hline 80 & .80 & 7.630 & 33.306 & 6.52 & 10.10 & 7.622 & 26.021 & .95 & .158 \\
\hline 99 & 100 & 7.640 & 33.307 & 6.37 & 9.13 & 7.631 & 26.020 & .95 & .196 \\
\hline \multicolumn{10}{|l|}{118} \\
\hline .137. & 138 & 7.170 & 33.307 & 6.20 & 9.22 & 7.157 & 26.087 & 1.00 & .272 \\
\hline 140 & 141 & 7.830 & 33.559 & 5.65 & 11.75 & 7.816 & 26.191 & 1.07 & .278 \\
\hline 153 & .154 & 7.510 & 33.653 & 4.93 & 14.57 & 7.495 & 26.311 & 1.26 & .301 \\
\hline 157 & 158 & 7.740 & 33.567 & 5.52 & 10.49 & 7.725 & 26.211 & 1.15 & .309 \\
\hline 167 & 168 & 7.370 & 33.691 & 4.82 & 14.66 & 7.354 & 26.361 & 1.34 & .327 \\
\hline 176 & 177 & 7.510 & 33.598 & 5.35 & 12.72 & 7.493 & 26.268 & 1.31 & .342 \\
\hline 181 & 182 & 7.290 & 33.780 & 4.72 & 15.15 & 7.273 & 26.442 & 1.42 & .351 \\
\hline 195 & 196 & 7.110 & 33.917 & 4.56 & .16 .90 & 7.092 & 26.575 & 1.49 & .373 \\
\hline 209 & & & 34.031 & 4.30 & 18.06 & & . & 1.53 & \\
\hline 223 & 224 & 7.170 & 34.069 & 4.33 & 18.45 & 7.149 & 26.686 & 1.57 & .414 \\
\hline 237 & 239 & 7.180 & 34.098 & 4.51 & 19.52 & 7.158 & 26.708 & 1.60 & .434 \\
\hline 246 & 248 & 7.200 & 34.102 & 4.30 & 19.52 & 7.177 & 26.709 & 1.60 & .446 \\
\hline 256 & 258 & 1.220 & 34.109 & 4.28 & & 7.196 & 20.711 & -- & .460 \\
\hline
\end{tabular}




\section{STATION 21.51}

\section{BODMAN CASTS}

(VTB)

\begin{tabular}{|c|c|c|c|c|}
\hline $\begin{array}{l}\text { Bodman Wire } \\
\text { Out. }\end{array}$ & $\begin{array}{l}\text { Nansen Calc. } \\
\text { Depth }\end{array}$ & ${ }^{\circ} \mathrm{C}$. & $\begin{array}{l}\text { Nansen } \\
\text { Sal. . \% oo }\end{array}$ & $\begin{array}{l}\text { Bodman } \\
\text { Sal. } 0 / 00\end{array}$ \\
\hline
\end{tabular}

Surface from. S. W. Tine

$\begin{array}{lrrrr}50 & 43 & 7.38 & 33.375 & 33.379 \\ 50^{\mathrm{F}} & 44 & 7.40 & 33.383 & 33.373 \\ 100 & 96 & 7.36 & 33.373 & 33.395 \\ 150^{\mathrm{F}} & 141 & 7.45 & 33.602 & 33.621 \\ 200 & 193 & 7.28 & 33.812 & 33.897 \\ 250^{\mathrm{F}} & 244 & 7.23 & 34.116 & 34.141 \\ 275 & & 7.23 & 34.118 & 34.120\end{array}$


STATION 2151

BODMAN CASTS

(MB)

\begin{tabular}{|c|c|c|c|c|}
\hline $\begin{array}{l}\text { Bodman Wire } \\
\text { Out }\end{array}$ & $\begin{array}{l}\text { Nansen Calc. } \\
\text { Depth }\end{array}$ & $\begin{array}{l}\text { Temp. } \\
{ }^{\circ} \mathrm{C}\end{array}$ & $\begin{array}{l}\text { Nansen } \\
\text { Sal. } 0 / 00\end{array}$ & $\begin{array}{l}\text { Bodman } \\
\text { Sal. } \% \text {.00 }\end{array}$ \\
\hline 10 & $\cdot-$ & - & & 33.390 \\
\hline 40 & $: \quad 37$ & 7.47 & 33.305 & 33.309 \\
\hline 70 & 65 & 7.46 & 33.396 & 33.396 \\
\hline 100 & 95 & 7.54 & 33.438 & 33.471 \\
\hline 130 & 123 & 7.74 & 33.532 & 33.557 \\
\hline 160 & 154. & 7.45 & 33.618 & 33.659 \\
\hline 190 & 181 & 7.29 & 33.789 & $\begin{array}{ll}\cdots \quad 33.859\end{array}$ \\
\hline 220 & 208 & 7.09 & 33.986 & 34.020 \\
\hline 250 & - & - & 34.015 & 34.131 \\
\hline
\end{tabular}


APPENDIX 4

Particulate matter concentration data 
STATION? ???

\begin{tabular}{|c|c|c|c|}
\hline Corr. Depth & Wtr. Vol. & $\begin{array}{c}\text { Part. Wt. } \\
\text { mg. }\end{array}$ & $\begin{array}{c}\text { Part. Conc. } \\
\mu \mathrm{g} / \mathrm{kg}\end{array}$ \\
\hline 0 & 8.1 & .718 & 88.64 \\
\hline 5 & 8.4 & :719 & 85.59 \\
\hline 10 & 9.2 & .779 & 84.67 \\
\hline 20 & 8.8 & .778 & 88.41 \\
\hline 35 & 4.3 & .354 & 82.32 \\
\hline 50 & 8.4 & 1.047 & 124.64 \\
\hline 74 & 4.8 & .501 & 104.37 \\
\hline 98 & 8.3. & .806 & 97.11 \\
\hline 99 & 9.5 & .713 & 75.05 \\
\hline 121 & 8.6 & .851 & $98: 95$ \\
\hline 124 & 9.4 & .747 & 79.47 \\
\hline 144 & 8.7 & .713 & 81.95 \\
\hline 149 & 10.2 & 1.083 & 106.18 \\
\hline 168 & 9.6 & 941 & 98.02 \\
\hline 189 & 10.5 & 1.120 & 106.67 \\
\hline 204 & 9.2 & 1.404 & 152.61 \\
\hline 223 & 7.9 & 1.479 & 187.21 \\
\hline 232 & 7.6 & 2.226 & 292.89 \\
\hline 242 & 6.8 & 2.195 & 322.79 \\
\hline 251. & 7.5 . & 2.547. & 339.60 \\
\hline
\end{tabular}




\section{STATION 2128}

\begin{tabular}{|c|c|c|c|}
\hline$\underset{M}{\text { Corr. Depth }}$ & $\begin{array}{c}\text { Wtr. Vol. } \\
\text { L. }\end{array}$ & $\begin{array}{c}\text { Part. Wt. } \\
\text { mg. }\end{array}$ & $\begin{array}{c}\text { Part. Conc. } \\
\mu \mathrm{g} / \mathrm{kg}\end{array}$ \\
\hline 0 & 7.8 & .934 & 119.74 \\
\hline 45 & 7.9 & 1.143 & 144.68 \\
\hline 69 & 7.5 & .947 & 126.27 \\
\hline 94 & 8.1 & .985 & 121.60 \\
\hline 119 & 8.3 & 1.063 & 128.07 \\
\hline 144. & 8.7 & 1.449 & 166.55 \\
\hline 168 & .8 & .145 & 181.25 \\
\hline 193 & 11.9 & 1.348 & 113.28 \\
\hline 218 & 8.0 & 2.380 & 297.50 \\
\hline 243 & 8.8 & 3.016 & 342.73 \\
\hline
\end{tabular}


STATION 2144

\begin{tabular}{rrrr}
${ }_{\ddot{M}}^{\text {Corr. Depth }}$ & $\begin{array}{c}\text { Wtr. Vol. } \\
\text { L. }\end{array}$ & $\begin{array}{c}\text { Part. Wt. } \\
\mathrm{mg}\end{array}$ & $\begin{array}{c}\text { Part. Conc. } \\
\mu \mathrm{g} / \mathrm{kg}\end{array}$ \\
\hline 2 & 7.0 & .964 & 137.71 \\
33 & 7.0 & .816 & 116.57 \\
63 & 7.5 & .862 & 114.93 \\
94 & 11.5 & 1.037 & 90.17 \\
120 & 11.5 & .947 & 82.35 \\
148 & 9.0 & 1.960 & 217.78 \\
178 & 8.0 & 1.911 & 238.87 \\
207 & 9.0 & 4.635 & 515.0 \\
225 & 9.8 & 4.769 & 541.93 \\
235 & 9.2 & 4.805 & 522.28
\end{tabular}




\section{STATION 2138}

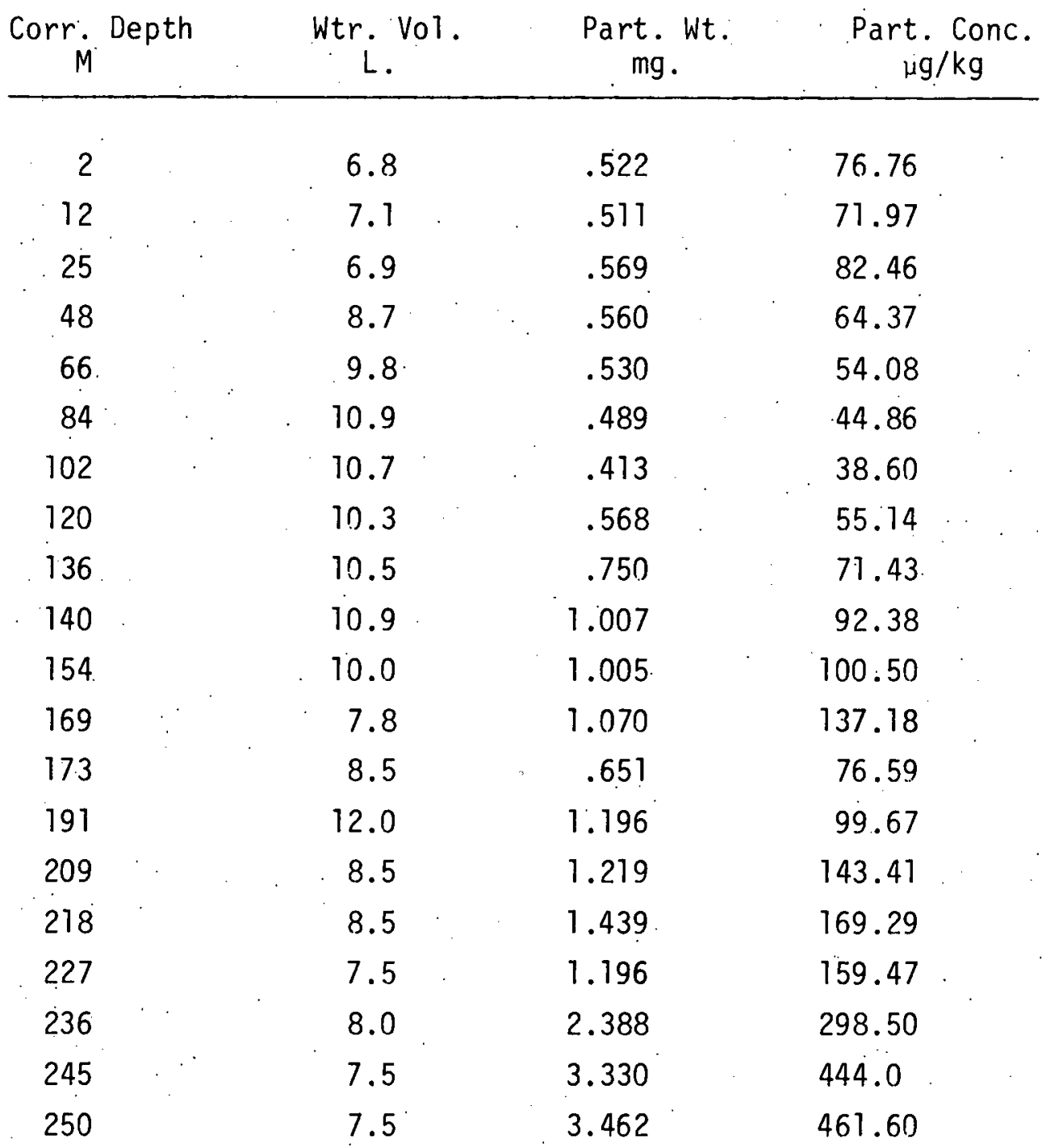


STATION 2149

\begin{tabular}{rrrr}
$\begin{array}{c}\text { Corr. Depth } \\
M\end{array}$ & $\begin{array}{c}\text { Wtr. Vol. } \\
\text { L. }\end{array}$ & $\begin{array}{c}\text { Part. Wt. } \\
\text { mg. }\end{array}$ & $\begin{array}{c}\text { Part. Conc. } \\
\mu \mathrm{g} / \mathrm{kg}\end{array}$ \\
\hline 5 & 7.2 & 1.818 & 252.50 \\
26 & 8.0 & .906 & 113.25 \\
51 & 8.1 & .859 & 106.05 \\
82 & 9.0 & 1.172 & 130.22 \\
102 & 8.7 & 1.301 & 149.54 \\
128 & 10.8 & 2.295 & 212.50 \\
153 & 9.7 & 1.834 & .189 .07 \\
184 & 9.0 & 2.378 & 264.22 \\
194 & 7.8 & 3.438 & 440.77 \\
209 & 8.0 & 4.097 & 512.12
\end{tabular}




\section{STATION 2151}

\begin{tabular}{rccc}
$\begin{array}{c}\text { Corr. Depth } \\
M\end{array}$ & $\begin{array}{c}\text { Wtr. Vol. } \\
\text { L. }\end{array}$ & $\begin{array}{c}\text { Part. Wt. } \\
\mathrm{mg}\end{array}$ & $\begin{array}{r}\text { Part. Conc. } \\
\mu \mathrm{g} / \mathrm{kg}\end{array}$ \\
\hline 1 & 9.9 & .554 & 55.96 \\
21 & .75 & .124 & 165.33 \\
42 & 10.5 & .657 & 62.57 \\
62 & 10.0 & .625 & 62.50 \\
80 & 10.5 & .609 & 58.0 \\
99 & 9.8 & .627 & 63.98 \\
118 & - & .050 & - \\
137 & 10.5 & .694 & 66.09 \\
140 & 9.25 & .904 & 97.73 \\
153 & 2.5 & .276 & 110.40 \\
157 & 11.0 & .792 & 72.00 \\
167 & 8.75 & 1.686 & 192.69 \\
176 & 9.0 & 1.100 & 122.22 \\
181 & 8.5 & 2.087 & 245.53 \\
195 & 7.25 & 1.814 & 250.21 \\
209 & 9.25 & 2.260 & 244.32 \\
223 & 8.25 & 2.110 & 255.76 \\
237 & 7.5 & 2.788 & 371.73 \\
246 & 8.5 & 3.524 & 414.59 \\
256 & 7.75 & 3.681 & 474.97
\end{tabular}




\section{List of Publications and Reports}

Supported by Contract AT(11-1)-3566

Formerly AT(30-1)-4150

NY0-4150-1 Sachs, P. L. and D. W. Spencer (1970)

In situ measurement of light scattered from a laser beam compared to suspended particulate concentrations derived from concurrently collected samples

\section{W.H.0.I. Technical Report}

NY0-4150-2 The distribution of some chemical elements between dissolved and particulate phases in the ocean

Report to AEC on Contract AT(30-1)-4150, 1969-70

NY0-4150-3 Turner, J. S., T. G. Shirtcliffe and P. G. Brewer (1970) Variations of transport coefficients across density interfaces in multiple diffusive systems

Nature, $\underline{228}, 1083$

NY0-4150-4 Spencer, D. W., D. E. Robertson, K. K. Turekian and T. R. Folsom (1970)

Trace element intercalibrations and profiles at the GEOSECS test station in the northeast Pacific 0cean

$$
\text { J. Geophys. Res., 75, } 7688
$$

NY0-4150-5 Brewer, P. G. and D. W. Spencer (1970)

Trace element intercalibrations study

W.H.O.I. Technical Report No. 70-62

NY0-4150-6 Brewer, P. G. and D. W. Spencer (1971)

Colorimetric determination of manganese in anoxic water's

$$
\text { Limno1. \& Ocean., 16, } 107
$$

NY0-4150-7 Spencer, D.W. and P. G. Brewer (1971)

Vertical advection, diffusion and redox potentials as controls on the distribution of $M n$ and other trace metals dissolved in waters of the Black Sea 


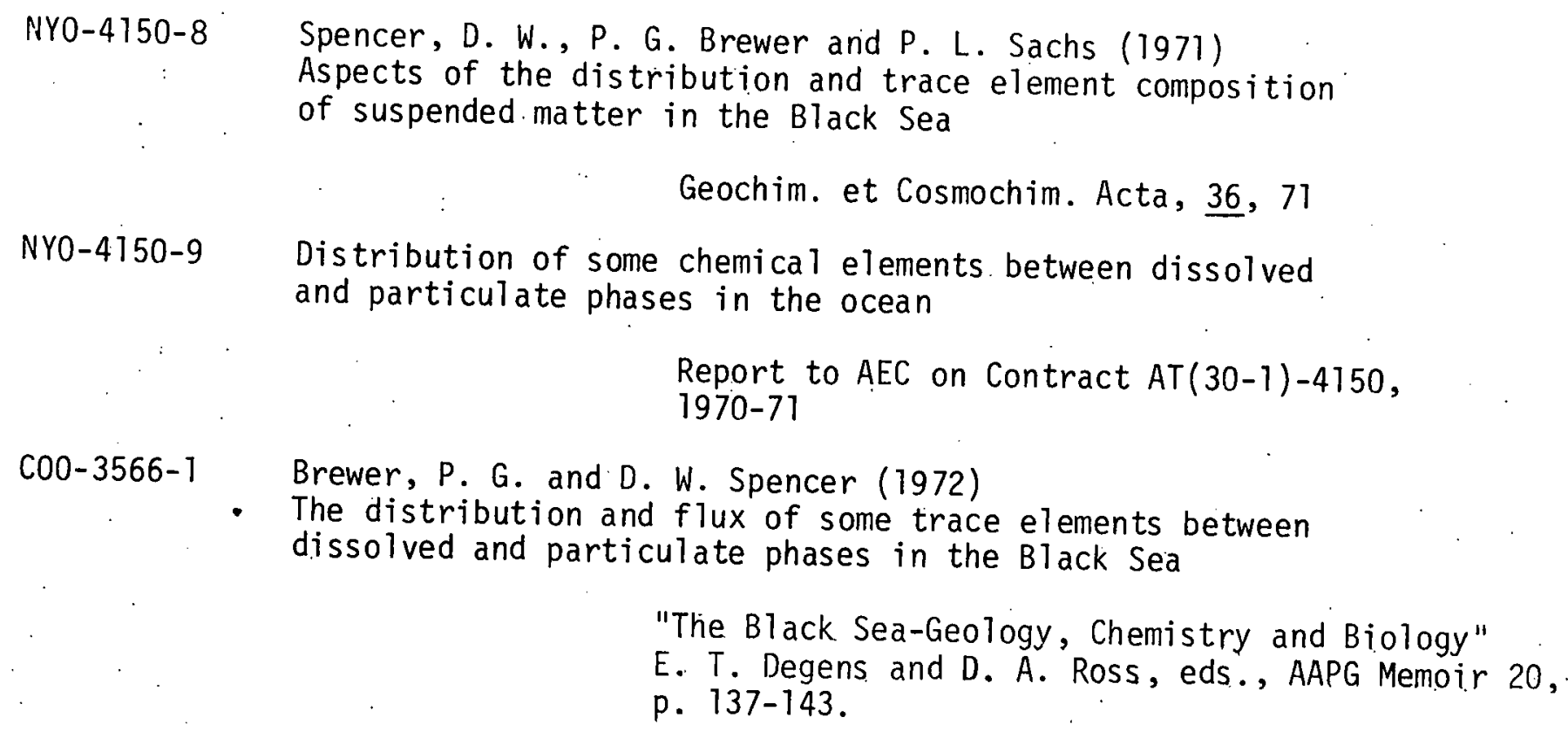

"The Black Sea-Geology, Chemistry and Biology"

E. T. Degens and D. A. Ross, eds., AAPG Memoir 20, p. 137-143.

C00-3566-2 Brewer, P. G., D. W. Spencer and D. E. Roberts on (1972) Trace element profiles from the GEOSECS test station in the Sargasso Sea

Earth \& Planet. Sci. Lett., 16, 111-116

c00-3566-3 Distribution of some chemical elements between dissolved and particulate phases in the ocean

Report to AEC on Contract AT(11-1)-3566,

C00-3566-4 Distribution of some chemical elements between dissolved and particulate phases in the ocean Report to AEC on Contract AT(11-1)-3566,
$1972-73$

Co0-3666-5 Brewer, P. G. and J. W. Murray (1973).

Carbon, nitrogen and phosphorus in the Black sea

Deep Sea Res., 20, 803-818

C00-3566-6 Murray, J.W. (1974)

The Surface Chemistry of Hydrous Manganese Dioxide

J. Colloid and Interface Science, 46,357 
C00-3566-7. Brewer, P. G.

Warming of deep water in the Cariaco Trench

In preparation

C00-3566-8 Murray, J. W. (1975).

The Interaction of Cobalt with Hydrous Manganese Dioxide

Geochim. et Cosmochim. Acta (in press)

C00-3566-9 Murray, J. W. (1975).

The Interaction of Metal Ions at the Manganese Dioxide-Solution Interface

Geochim. et Cosmochim. Acta, 39, 505, 519

C00-3566-10 The Distribution of Some Chemical Elements Between Dissolved and Particulate Phases in Sea Water.

Report to AEC on. Contract AT(11-1)-3566, 1973-74.

C00-3566-11 The Distribution of Some Chemical Elements Between Dissolved and Particulate Phases in Sea Water

Report to AEC on Contract AT(11-1)-3566, 1974-75

C00-3566-12 Brewer, P. G. (1975)

Minor Elements in Sea Water. In "Chemical Oceanography", Vol. 1, Second Edition, J. P. Riley and G. Skirrow, Eds., Academic Press, London

C00-3566-13 Brewer, P. G. and Spencer, D. W. (1975)

Minor Element Models in Coastal Waters. In "Marine Chemistry in the Coastal Environment", A.C.S. Symposium Series Volume.

(In press). 